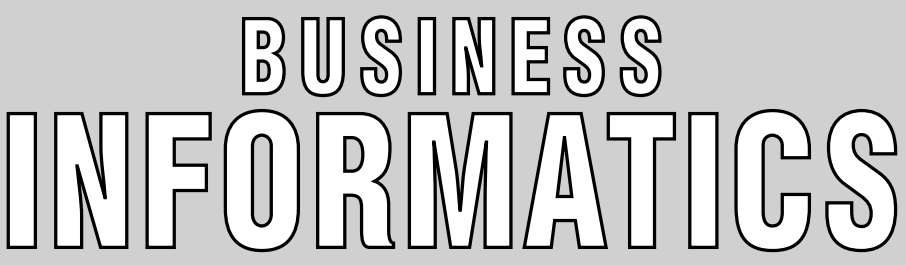

HSE SCIENTIFIC JOURNAL

\title{
CONTENTS
}

\section{Modeling of social and economic systems}

E.Z. Zinder

Expanding enterprise engineering paradigm

\section{Internet technologies}

\section{K.A. Kniazev, M.M. Komarov}

Infological models for smart commerce

\section{D.A. Aldunin}

Application of the adaptive content concept

for an e-learning resource

\section{Business processes modeling and analysis}

A.I. Kolomiets, O.V. Maksimenkova,

A.A. Neznanov

On business processes of computer-supported collaborative learning: A case of peer assessment system development

\section{Mathematical methods and algorithms of business informatics}

\section{A.I. Maron}

Assessment of service quality for complex technical devices based on the Jaynes' information principle

\section{Yu.V. Minaeva}

Adaptive modification of the particle swarm method based on dynamic correction of the trajectory of movement of individuals in the population

\section{Information systems and technologies in business}

N.F. Altukhova, E.V. Vasileva, B.B. Slavin

Concept for a new approach to project management in the activities of public servants

D.V. Isaev

Decision making using a combination of management accounting and an expert approach

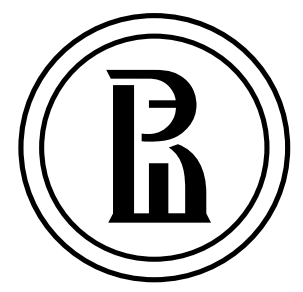

Publisher:

National Research University Higher School of Economics

Subscription index in the «Rospechat» catalogue 72315

The journal is published quarterly

The journal is included into the list of peer reviewed scientific editions established by the Supreme Certification Commission of the Ministry of Education and Science of the Russian Federation

$$
\begin{gathered}
\text { Editor-in-Chief: } \\
\text { A. Golosov } \\
\text { Deputy Editor-in-Chief } \\
\text { Y. Koucheryavy } \\
\text { Computer Making-up: } \\
\text { O. Bogdanovich }
\end{gathered}
$$

Website Administration:

I. Khrustaleva

33, Kirpichnaya Street, Moscow, 105187, Russian Federation

Tel./fax: +7 (495) 771-32-38 http://bijournal.hse.ru E-mail: bijournal@hse.ru

Circulation - 500 copies

Printed in HSE Printing House 3, Kochnovsky Proezd, Moscow, Russian Federation

(C) National Research University Higher School of Economics 
$\mathrm{B}$

usiness Informatics is a peer reviewed interdisciplinary academic journal published since 2007 by National Research University Higher School of Economics (HSE), Moscow, Russian Federation. The journal is administered by School of Business Informatics. The journal is published quarterly.

The mission of the journal is to develop business informatics as a new field within both information technologies and management. It provides dissemination of latest technical and methodological developments, promotes new competences and provides a framework for discussion in the field of application of modern IT solutions in business, management and economics.

The journal publishes papers in the areas of, but not limited to:

$\downarrow$ data analysis and intelligence systems

$\checkmark$ information systems and technologies in business

$\uparrow$ mathematical methods and algorithms of business informatics

$\downarrow$ software engineering

$\downarrow$ Internet technologies

$\uparrow$ business processes modeling and analysis

$\uparrow$ standardization, certification, quality, innovations

$\uparrow$ legal aspects of business informatics

$\downarrow$ decision making and business intelligence

$\uparrow$ modeling of social and economic systems

$\uparrow$ information security.

The journal is included into the list of peer reviewed scientific editions established by the Supreme Certification Commission of the Ministry of Education and Science of the Russian Federation.

The journal is included into Russian Science Citation Index (RSCI) database on the Web of Science platform.

International Standard Serial Number (ISSN) 1998-0663.

Editor-in-Chief: Dr. Alexey Golosov - President of FORS Development Center, Moscow, Russian Federation. 


\section{EDITORIAL BOARD}

\section{EDITOR-IN-CHIEF}

Dr. Alexey GOLOSOV -

President of FORS Development Center, Russian Federation

\section{DEPUTY EDITOR-IN-CHIEF}

\section{Dr. Yevgeni KOUCHERYAVY -}

Professor, Department of Electronics and Communication Engineering, Tampere University of Technology, Finland

\section{EDITORIAL BOARD}

\section{Dr. Habib ABDULRAB -}

Professor, Mathematical and Software Engineering Department, National Institute of Applied Sciences - Institut national des sciences appliquées de Rouen (INSA de Rouen), Rouen, France

\section{Dr. Sergey AVDOSHIN -}

Professor, Head of School of Software Engineering,

National Research University Higher School of Economics, Russian Federation

\section{Dr. Andranik AKOPOV -}

Professor, Department of Business Analytics, National Research University Higher School of Economics, Russian Federation

\section{Dr. Fuad ALESKEROV -}

Professor, Head of Department of Mathematics, National Research University Higher School of Economics, Russian Federation

\section{Dr. Anton AFANASYEV -}

Leading Researcher, Laboratory of Social Modeling, Central Economics and Mathematics Institute, Russian Academy of Science, Russian Federation

\section{Dr. Eduard BABKIN -}

Professor, Department of Information Systems and Technologies, National Research University Higher School of Economics, Russian Federation

\section{Dr. Alex BAYER -}

Head of KAFAN FX Information Services, New York, USA

\section{Dr. Alexander BARANOV}

Deputy Head of Central Scientific and Research Computing Center, Federal Tax Service of Russia, Russian Federation

\section{Dr. Jorg BECKER -}

Vice-Rector, Professor, Director of European Research Center for Information Systems (ERCIS), University of Munster, Germany

\section{Dr. Vladimir BELOV}

Professor, Department of Computational and Applied Mathematics, Ryazan State Radio Engineering University, Russian Federation

\section{Dr. Andrey GRIBOV -}

Director General, CyberPlat Company, Russian Federation

\section{Dr. Alexander GROMOV-}

Professor, Head of Department of Modeling and Business Process Optimization, National Research University Higher School of Economics, Russian Federation

\section{Dr. Vladimir GURVICH -}

Invited Professor and Researcher, Rutgers Center for Operations Research, Rutgers, The State University of New Jersey, USA

\section{Dr. Laurence JACOBS -}

Professor, Medical School, University of Zurich, Switzerland

\section{Dr. Iosif DISKIN -}

Academic Supervisor, Chairmen of Scientific and Expert Council, Russian Public Opinion Research Center (VCIOM); Member of the Council, The Russian Public Chamber; Russian Federation

\section{Dr. Kurt SANDKUHL -}

Professor, Head of Department of Business Information Systems, University of Rostock, Germany

\section{Dr. Nikolay ILYIN -}

Deputy Head, Administration of Special Communication, Federal Security Guard, Russian Federation

\section{Dr. Dmitry ISAEV -}

Associate Professor, Department of Business Analytics, National Research University Higher School of Economics, Russian Federation

Dr.Valery KALYAGIN -

Professor, Head of Department of Applied Mathematics and Informatics, National Research University Higher School of Economics, Russian Federation

Dr. Maria KAMENNOVA -

Director General, BPM Logic, Russian Federation

Dr. Tatiana KRAVCHENKO -

Professor, Head of Department of Business Analytics, National Research University Higher School of Economics, Russian Federation

\section{Dr. Sergey KUZNETSOV -}

Professor, Head of School of Data Analysis and Artificial Intelligence, National Research University Higher School of Economics, Russian Federation

\section{Dr. Mikhail LUGACHEV -}

Professor, Head of Department of Economic Informatics, Lomonosov Moscow State University, Russian Federation

\section{Dr. Svetlana MALTSEVA -}

Professor, Head of Department of Innovation and Business in Information Technologies, National Research University Higher School of Economics, Russian Federation

\section{Dr. Peter MAJOR -}

Vice-chairman, Radiocommunication Advisory Group of International Telecommunication Union (ITU),

vicece-chairman of the UN Commission on Science and Technology for Development (CSTD), Geneva, Switzerland

\section{Dr. Boris MIRKIN -}

Professor, School of Data Analysis and Artificial Intelligence, National Research University Higher School of Economics, Russian Federation

Dr. Vadim MOTTL -

Professor, Department of Information Security Management, Tula State University, Russian Federation

\section{Dr. Dmitry PALCHUNOV -}

Head of Department of General Informatics, Novosibirsk State University, Russian Federation

\section{Dr. Panagote (Panos) PARDALOS -}

Distinguished Professor and University of Florida Research

Foundation Professor, Director of Center for Applied Optimization, Department of Industrial and Systems Engineering, University of Florida, USA

Dr. Albert SILANTYEV -

Professor, Department of Information Business Systems, National University of Science and Technology «MISIS», Russian Federation

\section{Dr. Victor TARATOUKHIN -}

Managing Director, European Research Center for Information Systems (ERCIS), University of Munster, Germany

Dr. Mikhail ULYANOV -

Professor, School of Software Engineering,

National Research University Higher School of Economics,

Russian Federation 


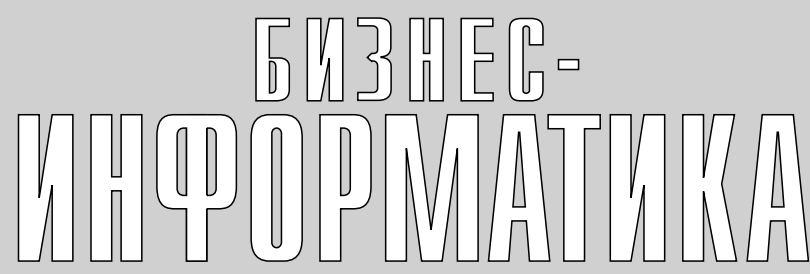

НАУЧНЫЙ ЖУРНАЛ НИУ ВШЭ

\section{С ОДЕРЖАН И Е}

\section{Моделирование социальных и экономических систем}

E.3. Зиндер

Расширяющаяся парадигма инжиниринга предприятия 7

\section{Интернет-технологии}

\section{К.А. Князев, М.М. Комаров}

Инфологические модели для умной коммерции

Д.А. Алдунин

Применение концепции адаптивного контента

для электронного образовательного ресурса

\section{Моделирование и анализ бизнес-процессов}

А.И. Коломиеи, О.В. Максименкова,

A.A. Незнанов

О бизнес-процессах коллаборативного обучения

и его компьютерной поддержки:

Разработка системы взаимного оценивания

\section{Математические методы и алгоритмы бизнес-информатики}

\section{А.И. Марон}

Оценка качества обслуживания сложных

технических устройств на основе

информационного принципа Джейнса ...

\section{Ю.В. Минаева}

Адаптивная модификация метода роя частиц на основе динамической коррекции траектории движения особей в популяции

\section{Информационные системы и технологии в бизнесе}

\section{Н.Ф. Алтухова, Е.В. Васильева, Б.Б. Славин}

Концепция нового подхода к управлению проектами в деятельности государственных служащих

\section{Д.В. Исаев}

Принятие решений на основе сочетания управленческого учета и экспертного подхода

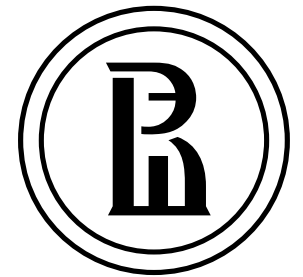

$$
\text { Издатель: }
$$

Национальный исследовательский университет «Высшая школа экономики»

Подписной индекс

в каталоге агентства

«Роспечать» -72315

Выпускается ежеквартально

Журнал включен в Перечень российских рецензируемых научных журналов,

в которых должны быть

опубликованы основные научные

результаты диссертаций на соискание ученых степеней доктора и кандидата наук

Главный редактор А.О. Голосов

Заместитель главного редактора Е.А. Кучерявый

Компьютерная верстка О.А. Богданович

Администратор веб-сайта И.И. Хрусталёва

Адрес редакции: 105187, г. Москва, ул. Кирпичная, д. 33

Тел./факс: 7 (495) 771-32-38 http://bijournal.hse.ru

E-mail: bijournal@hse.ru

За точность приведенных сведений и содержание данных, не подлежащих открытой публикации, несут ответственность авторы

При перепечатке ссылка на журнал «Бизнес-информатика» обязательна

Тираж 500 экз.

Отпечатано в типографии НИУ ВШЭ г. Москва, Кочновский проезд, 3

(c) Национальный исследовательский университет «Высшая школа экономики» 


\section{O XКРНA^E}

$\ll \mathrm{B}$

изнес-информатика» - рецензируемый междисциплинарный научный журнал, выпускаемый с 2007 года Национальным исследовательским университетом «Высшая школа экономики» (НИУ ВШЭ). Администрирование журнала осуществляется школой бизнес-информатики НИУ ВШЭ. Журнал выпускается ежеквартально.

Миссия журнала - развитие бизнес-информатики как новой области информационных технологий и менеджмента. Журнал осуществляет распространение последних разработок технологического и методологического характера, способствует развитию соответствующих компетенций, а также обеспечивает возможности для дискуссий в области применения современных информационно-технологических решений в бизнесе, менеджменте и экономике.

Журнал публикует статьи по следующей тематике:

\ анализ данных и интеллектуальные системы

४ информационные системы и технологии в бизнесе

\ математические методы и алгоритмы бизнес-информатики

программная инженерия

$\uparrow$ Интернет-технологии

моделирование и анализ бизнес-процессов

$\checkmark$ стандартизация, сертификация, качество, инновации

$\checkmark$ правовые вопросы бизнес-информатики

↔ринятие решений и бизнес-интеллект

моделирование социальных и экономических систем

$\checkmark$ информационная безопасность.

В соответствии с решением президиума Высшей аттестационной комиссии Российской Федерации журнал включен в Перечень российских рецензируемых научных журналов, в которых должны быть опубликованы основные научные результаты диссертаций на соискание ученых степеней доктора и кандидата наук, по следующим группам научных специальностей: 05.13 .00 - информатика, вычислительная техника и управление; 05.25 .00 - документальная информация; 08.00.00 - экономические науки.

Журнал входит в базу Russian Science Citation Index (RSCI) на платформе Web of Science.

Журнал зарегистрирован Федеральной службой по надзору в сфере связи, информационных технологий и массовых коммуникаций (Роскомнадзор), свидетельство ПИ № ФС77-66609 от 08 августа 2016 г.

Международный стандартный серийный номер (ISSN) 1998-0663.

Главный редактор: Голосов Алексей Олегович, кандидат технических наук, Президент компании «ФОРС - Центр разработки». 


\section{ГЛАВНЫЙ РЕДАКТОР}

ГОЛОСОВ Алексей Олегович -

кандидат технических наук, Президент компании «ФОРС Центр разработки»

\section{ЗАМЕСТИТЕЛЬ ГЛАВНОГО РЕДАКТОРА}

КУЧЕРЯВЫЙ Евгений Андреевич -

$\mathrm{PhD}$, профессор департамента электроники и коммуникаций, Технологический университет Тампере, Финляндия

\section{ЧЛЕНЫ РЕДКОЛЛЕГИИ}

АБДУЛЬРАБ Абиб -

$\mathrm{PhD}$, профессор департамента математики и программной инженерии, Национальный институт прикладных наук, Руан, Франция

\section{АВДОШИН Сергей Михайлович -}

кандидат технических наук, профессор, руководитель департамента программной инженерии, Национальный исследовательский университет «Высшая школа экономики»

\section{АКОПОВ Андраник Сумбатович -}

доктор технических наук, профессор кафедры бизнес-аналитики, Национальный исследовательский университет

«Высшая школа экономики»

\section{АЛЕСКЕРОВ Фуад Тагиевич -}

доктор технических наук, профессор, руководитель департамента математики, Национальный исследовательский университет «Высшая школа экономики»

\section{АФАНАСБЕВ Антон Александрович -}

доктор экономических наук, и.о. ведущего научного сотрудника лаборатории социального моделирования, Центральный экономико-математический институт РАН

\section{БАБКИН Эдуард Александрович -}

кандидат технических наук, $\mathrm{PhD}$, профессор кафедры информационных систем и технологий, Национальный исследовательский университет «Высшая школа экономики»

\section{БАЙЕР Алекс -}

$\mathrm{PhD}$, Директор KAFAN FX Information Services, Нью-Йорк, США

\section{БАРАНОВ Александр Павлович -}

доктор физико-математических наук, заместитель директора ФГУП «Главный научно-исследовательский вычислительный центр Федеральной налоговой службы»

\section{БЕККЕР Йорг -}

$\mathrm{PhD}$, проректор, профессор, директор Европейского исследовательского центра в области информационных систем (ERCIS) Мюнстерского университета, Мюнстер, Германия

\section{БЕЛОВ Владимир Викторович -}

доктор технических наук, профессор кафедры вычислительной и прикладной математики, Рязанский государственный радиотехнический университет

\section{ГРИБОВ Андрей Юрьевич -}

кандидат экономических наук, Генеральный директор компании «КиберПлат»

\section{ГРОМОВ Александр Игоревич -}

кандидат химических наук, профессор, заведующий кафедрой моделирования и оптимизации бизнес-процессов, Национальный исследовательский университет «Высшая школа экономики»

\section{ГУРВИЧ Владимир Александрович -}

$\mathrm{PhD}$, приглашенный профессор и исследователь,

Центр исследования операций, Ратгерский университет (Университет Нью-Джерси), США

\section{ДЖЕЙКОБС Лорени -}

$\mathrm{PhD}$, профессор медицинского факультета, Университет Цюриха, Швейцария

\section{ДИСКИН Иосиф Евгеньевич -}

доктор экономических наук, научный руководитель, председатель Научно-экспертного совета, Всероссийский центр изучения общественного мнения (ВЦИОМ); член Совета Общественной палаты Российской Федерации
ЗАНДКУЛЬ Курт -

$\mathrm{PhD}$, заведующий кафедрой информационных систем для бизнеса, Университет Ростока, Германия

\section{ИЛЬИН Николай Иванович -}

доктор технических наук, член-корреспондент Академии криптографии РФ, заместитель начальника Управления специальной связи, Федеральная служба охраны Российской Федерации (ФСО России)

\section{ИСАЕВ Дмитрий Валентинович -}

кандидат экономических наук, доцент кафедры бизнес-аналитики, Национальный исследовательский университет

«Высшая школа экономики»

\section{КАЛЯГИН Валерий Александрович -}

доктор физико-математических наук, профессор, заведующий кафедрой прикладной математики и информатики, Национальный исследовательский университет «Высшая школа экономики»

\section{КАМЕННОВА Мария Сергеевна -}

кандидат технических наук, Генеральный директор компании «Логика ВРМ»

\section{КРАВЧЕНКО Татьяна Константиновна -}

доктор экономических наук, профессор, заведующая кафедрой бизнес-аналитики, Национальный исследовательский университет «Высшая школа экономики»

\section{КУЗНЕЦОВ Сергей Олегович -}

доктор физико-математических наук, профессор, руководитель департамента анализа данных и искусственного интеллекта, Национальный исследовательский университет «Высшая школа экономики»

ЛУГАЧЕВ Михаил Иванович -

доктор экономических наук, профессор, заведующий кафедрой экономической информатики, Московский государственный университет им. М.В. Ломоносова

\section{МАЛЬЦЕВА Светлана Валентиновна -}

доктор технических наук, профессор, заведующая кафедрой инноваций и бизнеса в сфере информационных технологий,

Национальный исследовательский университет

«Высшая школа экономики»

\section{МЕЙОР Питер -}

$\mathrm{PhD}$, заместитель директора консультативной группы по радиокоммуникациям, Международный телекоммуникационный союз (ITU), заместитель руководителя Комиссии ООН по науке и технологиям, Женева, Швейцария

\section{МИРКИН Борис Григорьевич -}

доктор технических наук, профессор департамента анализа данных и искусственного интеллекта, Национальный исследовательский университет «Высшая школа экономики»

\section{МОТТЛЬ Вадим Вячеславович -}

доктор технических наук, профессор кафедры информационной безопасности, Тульский государственный университет

ПАЛЬЧУНОВ Дмитрий Евгеньевич -

доктор физико-математических наук, заведуюший кафедрой общей информатики, Новосибирский государственный университет

\section{ПАРДАЛОС Панайот (Панос) -}

$\mathrm{PhD}$, почетный профессор, директор центра прикладной оптимизации, департамент промышленной и системной инженерии, Университет Флориды, США

\section{СИЛАНТБЕВ Альберт Юрьевич -}

доктор технических наук, профессор кафедры информационных бизнес систем, Национальный исследовательский

технологический университет «МИСиС»

\section{ТАРАТУХИН Виктор Владимирович -}

кандидат технических наук, $\mathrm{PhD}$, руководитель научной группы Европейского исследовательского центра в области информационных систем (ERCIS) Мюнстерского университета, Мюнстер, Германия

\section{УЛЬЯНОВ Михаил Васильевич -}

доктор технических наук, профессор департамента программной инженерии, Национальный исследовательский университет «Высшая школа экономики» 


\title{
Expanding enterprise engineering paradigm ${ }^{1}$
}

\author{
Evgeny Z. Zinder \\ Chairman of the Board, NCO "Foundation for System Engineering, \\ Standardization and Project Management Support" (FOSTAS Foundation) \\ Address: mailbox 563, Moscow, 107061, Russian Federation \\ E-mail: ezinder@fostas.ru
}

\begin{abstract}
The nature of changes in the enterprise engineering paradigm and, in the first place, in the concepts of this complex discipline, is important for the selection of enterprise engineering (EE) areas development and forms of accumulation of knowledge in this area and their transfer to professionals, as well as for the stability and flexibility of application of EE in practice. Analysis of these changes is particularly important, due to the high turbulence of EE methods and technologies in the modern segment of technology development, productive and other relations, as well as due to the possibility of interpretation of private schemes and methods of EE as a new paradigm.
\end{abstract}

To give a meaningful estimate of changes in the EE paradigm, there have been defined basic and additional EE concepts that at the end of the 20th century formed the classical EE paradigm. The results of comparative analysis of classical EE paradigm concepts and the tasks which are common to various enterprises until 2030 have been set forth. These results demonstrated that the classical EE paradigm retains its performance ability in this perspective. The paper points out the open character of the set of EE paradigm concepts and methods, whereby its composition naturally comprises the concepts formulated already in the 21st century, as well as alternative concepts. Meanwhile, the total "picture of the EE world" does not change to something incompatible with the former one, but at the same time it does not remain unchanged: we see a permanent expansion of the EE paradigm due to new methods of implementing the concepts, as well as new concepts applied in parallel and in combination with the classical ones.

The conducted analysis has allowed us to pass on to the definition of substantively new concepts and emerging ones, to propose directions for further research, as well as to define the conditions under which the formation and application of a truly new EE paradigm can be justified.

Key words: enterprise, enterprise engineering, concept of engineering, information technology, digital transformation, classical paradigm, paradigm shift, expanding paradigm.

Citation: Zinder E.Z. (2016) Expanding enterprise engineering paradigm. Business Informatics, no. 4 (38), pp. 7-18. DOI: 10.17323/1998-0663.2016.4.7.18.

\section{Introduction}

$\mathrm{D}$ uring the last twenty-five years, enterprise engineering (EE) has been defined as a complex discipline that is used for creating and changing a wide variety of enterprises. In consequence of goaloriented international efforts, at the end of the 20th century there was created a body of concepts, methodolo- gies and standards which together form the classical EE paradigm. This body was aimed at supporting the activities of enterprises in the 21st century, and its openness, backed by the standards [1,2], made it possible to build up and modernize its methods.

The current period is characterized not only by the acceleration of development of technologies (not only

1 The present research paper has been executed within the framework of project RFBR 16-07-01062:

"Development of methods and resources of enterprise engineering based on the smart technologies". 
information technologies, but also robotics, biotechnology, etc.), but also by radical changes in the education, demography, sociology, and economics in general, and this fact changes the environment in which enterprises are created and operate. Starting from the very beginning of the 21st century, changes in individual disciplines related to the EE began to be perceived as significant paradigm shifts. Furthermore, an impression has formed that the effect of a permanent paradigm shift [3] appeared. Nowadays, publications about new paradigms or their shifts occur almost daily. Some presentation about the turbulence in EE concepts and methods is provided in research papers [4-10], although the full picture is wider and more varied.

Under these conditions, the following questions should be answered:

$\checkmark$ Does the classical EE paradigm remain operable today and in the near future, and to what extent?

$\downarrow$ Do changes in enterprises and their external environment really require a new EE paradigm (or, equivalently, its paradigm shift) that is a radically changed picture of the EE world?

$\downarrow$ What EE concepts and methods should be rightfully and reasonably considered as classical or relatively new ones, but requiring further research and development (R\&D)?

$\checkmark$ What substantially new concepts in various areas of EE is it appropriate to consider as objects and directions for further research?

$\downarrow$ What are the conditions that require the recognition of a truly new EE paradigm, and what in this recognition can have both objective and subjective grounds?

The answers to these questions and their discussion are rather important for determining reasonable methods of EE development, as well as for the possibility itself of the systematic knowledge accumulation in this field and for selection of forms of passing them to experts, as well as for the flexible and sustainable implementation of EE methods in practice. The paper suggests answers to the first two questions and, partially, to the third of these questions, based on the classical EE paradigm concept and its expansions and development prospects.

Section 1 presents the approaches and methods used in the research. Section 2 states the results of analysis of the classical EE paradigm basic concepts, as well as the concepts that have greatly supplemented the basic ones and together with them formed the classic enterprise engineering. Section 3 presents the most common assessments of the main current objectives of enterprise engineering, often referred to as the digital transforma- tion. The classical EE paradigm concepts are compared with the mentioned objectives, and on this basis, assessments of operability of the existing EE paradigm and of the grounds for its replacement are being formed. Section 4 provides a diagram demonstrating the expanding EE paradigm, covering the application of relatively new concepts and discussion of radically new ones. Finally, the general program for further research required to obtain answers to the remaining questions is outlined.

\section{Methodology of the research \\ 1.1. The bases of the analysis methodology}

The methodological basis of the analysis is a comprehensive approach to EE analysis, the basic provisions of the non-classical and post-non-classical epistemology, as well as the historical approach applied to the values that EE provides to enterprises and to the people related to them. The principles of non-classical and post-non-classical epistemology serve for the expansion of the analysis basis in terms of choice of criteria for the selection of knowledge categories for the EE in general and individual EE concepts, particularly in relation to knowledge management engineering at enterprises. The historical approach is applied to analyze EE concepts and methods not in abstract "time and space", but within a particular historical period possessing certain characteristics of the enterprise environment, including characteristics of both the productive forces and the productive and social relations, as well as their dynamics, namely, within the horizon from the early 90 s of the 20th century to 2030 . The historical approach to $E E$ is applied in its searching variant, aimed at analysis of the EE concepts with consideration of future conditions of the enterprise within the planning horizon under review.

\subsection{The governing points of view on $\mathbf{E E}$ and related concepts}

Points of view of customers and users of the engineering results, as well as independent consultants considering the enterprises transformation from the standpoint not of individual technologies, but of the economy and society in general were chosen as governing ones for the evaluation of EE concepts. Particularly, the most important ones considered were both the criticism of unjustified imposition of the enterprise transformation methods from the standpoints of practical marketing at the beginning of the 21st century [10] and evaluation by the marketing management practitioners of new opportunities one and a half decades later [11]. Current forecasts and recommendations for enterprises - leaders of the 
so-called "digital transformation" were also taken into consideration.

A broad interpretation of conception "paradigm" [9] was used which makes it possible to integrate the search for EE theoretical justifications with a leading practical development of the real EE, which, in fact, fuels the search for these justifications. The EE paradigm is considered at the level of its most general and fundamental premises considered as the EE concept. The emergence of new methods applied for the implementation of some or other concept, and, especially, of new tools and technologies, is not regarded as a paradigm shift.

The characteristics "digital" and "analog" are interpreted in accordance with the UN and the World Bank reports used in the paper, and these characteristics are not associated with a form of data storage and transmission.

\section{The classical paradigm of enterprise engineering and its first expansions}

\subsection{Creation of the classical paradigm}

The classical EE paradigm concepts are rather completely presented in certain methodologies and standards. Analysis of the emergence and development of the classical EE in the light of its architectural part is carried out by the author in [12]. For this reason, only distinctive features of the classical EE used for evaluating paradigm operability are described further in the paper.

It is significant that more than twenty years ago some methodologists expressed the opinion that the EE paradigm as a new professional discipline is determined in general, both the engineering and technocratic ones [13]. However, the practical EE has been developed with the help of a large range of specialists, and has integrated a wider range of the enterprise aspects; this has made it possible to include various and often opposed concepts in practical use in EE. At ICEMIT'97 conference, governing for the EE, the results of goal-oriented research and a combination of the approaches of European and American specialists were presented [14]. However, although the name "EE" was introduced earlier at ICEMIT'92, the content of this discipline still required definition. Significant projects of a conceptual nature contributed to this, and the paper [15] indicated focusing of the proposed concepts on ensuring of successful enterprises operation in the 21st century.

A consensus regarding the EE concepts was generally reached in 2000 which was reported by Kurt Kosanke, one of the EE ideologists, in a research paper [16]. The standards $[1,2]$ were approved that established the term "enterprise engineering" and the basic concepts of en- terprises integration and modeling, as well as a broad definition of the term "enterprise" and principles of EE implementation, including those based on the architectural approach. These and subsequent EE standards have been harmonized with the concepts of a number of methodologies still having independent significance.

\subsection{Basic concepts of the classical EE paradigm}

In this paper the author attributes the concepts that are set forth in descriptions of the projects and standards, which in fact have formed the basis of EE content, as basic. As such, in the first place this research paper considers projects GERAM [17], CIMOSA [18], GRAI-GIM [19] and Next-Generation Manufacturing (NGM) [15], as well as standards [1,2]. The basic concepts can be divided into the three provisional fields: concepts of $\mathrm{EE}$ arrangement as a whole, concepts of individual components or aspects of an enterprise, and concepts of approaches to the enterprise integration. This paper states the most significant and indicative concepts, and their sets in each field are defined as open ones.

The basic concepts of the classical EE as a whole are as follows:

- Interpretation of the EE object as an enterprise comprising the goal-oriented nature of its establishing, modifying and functioning, not limiting the legal, economic or other aspects of its organization, size and life history, and providing for virtual and extended enterprises;

$\downarrow$ Enterprise engineering as a course through the life cycles that are forming the enterprise life history, as a continuous process of forming and changing descriptions and models of the enterprise, their adaptation and implementation by means of creating operational components and monitoring their functioning;

$\downarrow$ Subject and discipline "Enterprise Architecture" as a part of EE;

$\downarrow$ A multilevel system of detailed and concretized descriptions, illustrative representations and other enterprise models of varying formalization degree (including glossaries, ontological theories, typical (reference) and specific models, architectural modules), as well as ready-made blocks;

- Agile production and flexible structure of an enterprise, control over the balance between integration and decentralization of the enterprise's development.

The basic concepts for the enterprise components are as follows: 
$\diamond$ People as the enterprise subjects (their roles, competences, and special properties, interaction with each other and with machines), as well as the enterprise culture - both general and production;

$\diamond$ Business model of the enterprise in general and the set of its constituent models for various aspects of the enterprise, including the financial and economic model of the enterprise as part of the business model;

$\diamond$ Value chains and performance models of the enterprise and its engineering, as well as their integration;

$\diamond$ Products and models of the products in its life cycle, as well as other assets (resources) of the enterprise and their models;

$\diamond \mathrm{A}$ broad concept of enterprise processes, including behavior acts, as well as taxonomies of processes;

$\diamond$ Machinery and technological systems, their models and specimens;

$\diamond$ Information and knowledge of the enterprise;

$\diamond$ Centers of decision-making in the enterprise, architecture of the set of these centers and their relationships;

Re-usable modules (architectural units, services, standard and typical systems, information resources, etc.), and flexible enterprise architecture;

$\diamond$ External environment of the enterprise and its components; interaction with partners in the extended enterprise.

The basic concepts of approaches towards the enterprise integration are as follows:

- Architectural analysis, design, and control as a high-level management of enterprise integration and development;

- Standardization and typification of architectures and individual models, modules typification;

$\downarrow$ Various (heterogeneous) representations of partial architectures and processes of modeling of the enterprise and its architecture targeted at EE various subjects;

Adaptation of the reference methodologies, architectures, and the EE entire framework to the conditions of a particular industry and enterprise;

$\downarrow$ Construction and continuous actualization of the enterprise ontology as an integrated formalized description of the enterprise components, including its management, as well as management of their properties and relationships;

$\downarrow$ Multi-level organizational, informational and other interoperability of the enterprise components and the enterprise with its partners;

$\downarrow$ Integration of various functional parts, organizational units, and enterprise processes; $\downarrow$ Integration of machines, computer systems, and people;

$\downarrow$ Integration of virtual and extended enterprises (employees and partners);

\ Modeling languages, repository of artifacts of architecture and of the entire process of enterprise engineering;

Application of various enterprise life cycle models for different engineering methods (business process reengineering, continuous process improvement, etc.);

$\downarrow$ Integration of work processes based on workflow models.

\subsection{Concepts of the 20th century supplementing the EE basic concepts}

Simultaneously with the formation of the basic concepts, concepts related to further development of capabilities of enterprises have also been proposed. These concepts are reflected in the aforementioned documents of the classical EE only partially, but by 2001 they had already been applied in practice. This fact allows us to consider that the classical EE paradigm has been formed as a combination of the basic concepts described above and the additional concepts discussed below.

\section{Concepts for cyber-corporation engineering}

$\mathrm{J}$. Martin introduced the idea of a cyber-corporation in the paper [20], and developed it in 1996 in his book [21], in which he proposed concepts that seemed to be revolutionary for the major part of enterprises. The basis consisted in requirements for enterprises to respond quickly to changes, to implement a "corporate nervous system" distributed to partners and customers, to transform enterprises on the basis of net-centric architectures and continuous evolution of corporations as "electronic organisms".

Amongst others, these concepts include in particular the following [21]:

$\diamond$ To expose to reengineering not business processes, but value streams, thereby obtaining clear and measurable benefits;

$\diamond$ To plan the strategic advantages basing on the most important value streams;

$\diamond$ To realize flexibility and agility of creation and cancellation of network organizational ties to respond quickly to business opportunities;

$\diamond$ To form ecosystems of the economy of cyber-corporations as multi-industry combinations of corporations with dynamic relationship management;

$\diamond$ To use software agents and smart "digital" documents having "embedded intelligence"; 
To manage the choreography of complex interactions with partners in the network;

$\diamond$ To take "paradoxical" (sudden, spontaneous, illogical from the point of view of observers) behavior into consideration;

$\diamond$ To design a cyber-corporation for very quick evolution;

$\diamond$ To design parts of a cyber-corporation as "learning laboratories" aimed at continuous experiment.

A section of the book [21] is devoted to concepts of involving people and management. Among other things, it proposes the following:

$\downarrow$ To create an attractive and motivating work environment as an "exciting" place for maximum creative activity;

$\downarrow$ To carry out continuous quick training of people and the whole cyber-corporation; to exclude any outdated thinking;

\ To look for ways of "smooth transformation" as opposed to traumatic one.

In fact, these concepts had not been absolutely revolutionary ones by 1996, because in many respects they were similar to the well-known BPR concepts of the 90s [22]. However, J. Martin proposed a new approach based not so much on processes but on values, taking into consideration the high volatility of the environment. This approach required from enterprises the quickest possible response both to the emerging opportunities and to the requirements for development, forcing them to rely on information technologies to the most extent with the goal of achieving such an effect that in ten and more years became known as "digital transformation".

\section{Concepts for "New System Design" (N.S.D.)}

In those same years, the author of this article in his papers [23, 24], along with an analysis of the existing approaches, has proposed a system of concepts for developing automated systems that implement the operating part of comprehensively computerized enterprises. The sum of the concepts was called the "New System Design" (N.S.D.); it has received a significant number of citations and was used in universities and research independently from the author. Partially, the N.S.D. concepts turned out to be intercrossing with the proposals of J. Martin [21], as well as with certain developments published later. Therefore, we will consider only those aspects that can supplement these proposals:

$\diamond$ “Information Systems" are not technologies, but a directly acting part of a business (enterprise); it is interpreted as the need to always create and develop IT systems within the frame of business-engineering projects;

$\diamond$ An open "EE shop", extendable by means of alternative methods and tools in contrast to a "unitary" set of tools and predetermined methods;

Complete informational equipment of each employee, regardless of his position in the organizational structure.

\section{Concepts for electronic business enterprises}

In 1998, P. Timmers analyzed business models of electronic business enterprises in the paper [25], the number of citations of which has been increasing over the years. As a consequence, he, in fact, highlighted the concept of an "enterprise as a platform" (EaaP), as well as implicitly suggested a taxonomy of transaction and innovative platforms (although such names were not used in his own work). Among those discussed, there are platforms suitable for the creation of ecosystems, including not only companies, but also end customers. P. Timmers stated that these business models are feasible only because of the openness and connectivity provided by the Internet. The paper [25] also considers the following:

- The concept of innovative enterprise business models including added value to the value chain due to new information management methods and new functionality;

- The concepts of an enterprise with models of a "collaboration platform" and "virtual community", which afterwards came to be considered as the basis of e-participation concepts in e-governments and found use in various forms of modern social networking on the web.

\section{About other classical concepts of the EE}

Within the limits of this publication, it is impossible to consider many important concepts of the classical EE paradigm, however, they are reflected in the publications mentioned above. As an example, we will mention two important concepts defined in the NGM project:

$\diamond$ In the aspect of skills and activities of companies in the 21st century: "partnerships will be formed based on trust rather than through detailed contract in order to solve complex problems quickly" [15, p. 8];

$\diamond$ In the aspect of supplementary methods and technologies: "Tools to mitigate the effects of physical and cultural complexity and to enable effective distributed, global operations across cultures" [15, p. 9]. 


\section{General stimuli and objectives of changing enterprises in the 21 st century}

To evaluate the operability of the classical EE paradigm, it is reasonable to highlight the objectives and methods of enterprises development which are called "digital transformation" (DT), that seem to be relevant in the selected horizon, and are the most common for enterprises in different countries. Such objectives and methods of development are determined in this paper basing on the researches of the World Bank [26] and the UN [27, 28].

\subsection{Report of the World Bank: "Digital dividends"}

The report [26] is coordinated with the plan for sustainable development [29] adopted by the UN for the period up to 2030. The report [26] considers digital technologies in the first place as the Internet and mobile communications, as well as related information technologies - business intelligence (including big data technologies), work automation, and remote teamwork platforms. For all the industry sectors, enterprise scopes and kinds of activities, consideration is given to three main "mechanisms" for DT [26] or, in effect, EE models: inclusion in the information space, automation and coordination to improve efficiency, and savings through scale and platform for creating innovations.

The report [26] demonstrates that within the terms of perspective under consideration EE will be applied to the fullest extent in the DT area, which we will call the first one - for the development and transformation of classical enterprises and processes of production of relatively traditional products and services. The main objectives consist of covering a larger number of market participants, acceleration of the enterprises response and improvement of the efficiency of production processes planning and implementation. To achieve these goals, such models as "Inclusion" and "Automation and coordination" (or EE efficiency model in Figure 1) are applied in the first place. They are located at the bottom of Figure 1 which presents the scheme of EE models for DT including and extending ideas of [26]. It should be also noted that these models are completely covered by the classical EE paradigm concepts and are largely tried and tested in practice.

For a clearer comparison of the classical EE concepts with the second relevant DT area discussed below let us take into consideration that the model "Savings through scale and platform" should be divided into two ones: "Transaction platform" and "Innovation platform", which are at the top of Figure 1. This division takes place in both the recent taxonomy of platforms [30] and in the classical taxonomy of Internet business models [25]. On conceptual level combination of relations between these four models (mechanisms for DT) forms the integration grid and serves as the fifth model for DT: "EE top level integration model". Due to that the scheme is named "Five-model EE scheme for DT" in this paper.
For what: reduction in transaction costs, increasing number of sellers and customers (cost saving due to the scale of work on the transactional side and eliminating of middlemen)
For what: increased competition ability, new quality (novelty products creation, rapid and constant update of products, co-creation, customer's involvement and participation)

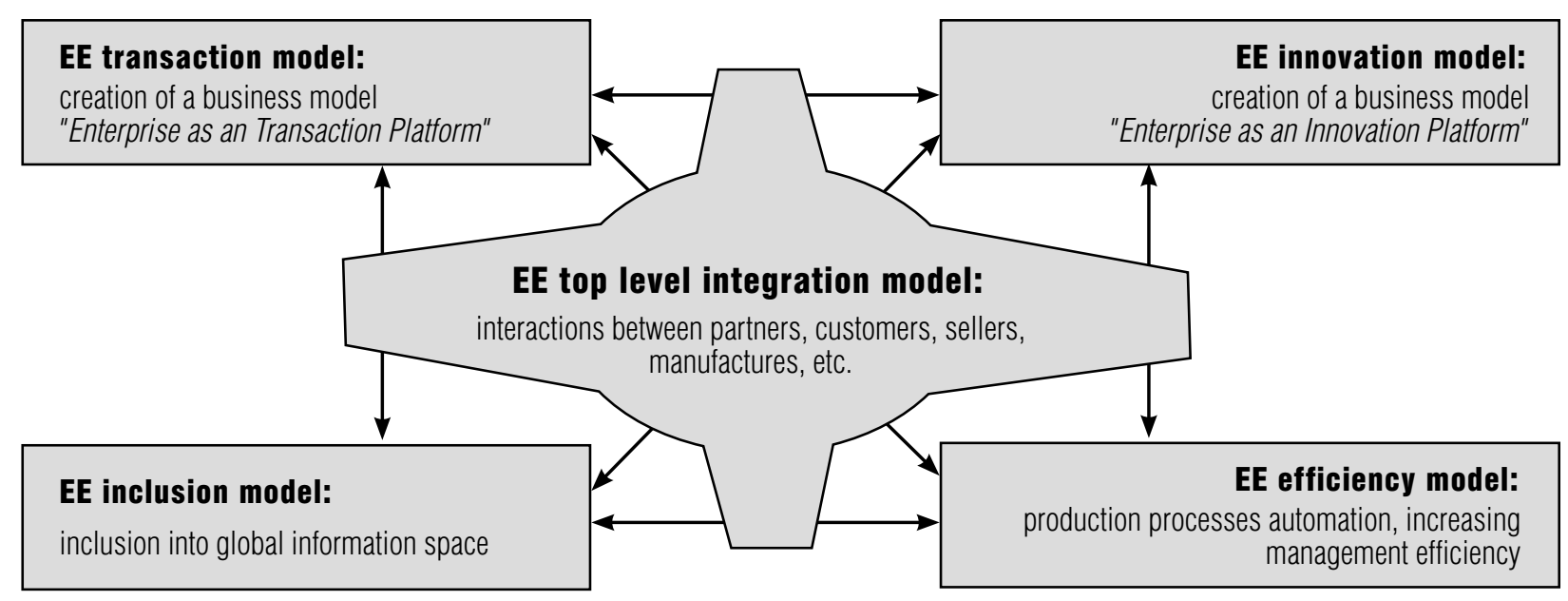

For what: coverage of a much larger space of distribution, customer settings, improving workflow

For what: a significant or even drastic increase in planning and production efficiency, quality of services and products

Fig. 1. The five-model scheme of $\mathrm{EE}$ for digital transformation of enterprises 
The second DT area covers those enterprises (divisions of enterprises), the production process of which is aimed at obtaining new or relatively innovative types of services in the form of information and communication results, primarily with the use of transaction and innovative platforms. The examples of application of the transaction platforms are electronic trading platforms or transfer of logistics and occasional services to the ICT sphere ("Uberization" - according to the operating model of Uber). The examples of application of the innovative platforms are the collective design of a new product at the site of a joint remote work or use of crowdsourcing to support decision-making about an urban area improvement. It can be noted that despite the relative novelty of such platforms, the classical EE basic concepts and models work in this engineering as well.

The report [26] brings ensuring of connectivity of organizations and people through the Internet and mobile communications to the leading position regarding the digital transformation effect. Undoubtedly, EE science intensive methods and intelligent technologies are also important. In classical EE, they are primarily used in the scope of the "Automation and coordination" model (EE efficiency model in Figure 1), but they are gradually extending into the interactions of subjects and mechanisms, as well as to transaction and innovative platforms. However, the report [26] considers these methods in the second turn, most likely because the DT realized basing on connectivity will remain of top priority for a long time.

\subsection{Reports of the United Nations} in 2014 and 2016 on e-government development

UN reports [27, 28] supplement the report [26] with an analysis of the public sector development. Their findings coincide with the conclusions of the report [26], but at the same time they improve some requirements for EE. Particularly, the following needs are emphasized:

$\diamond$ To use in EE not only informational, but also process connectivity of public sector organizations among themselves, with enterprises of other types, and with individuals, which increases the variability and complexity of enterprise management and requirements for security;

$\diamond$ To ensure in EE requirements the "e-participation" of citizens in order to achieve not personal objectives, but those common for the city, the region and the country.
The following should be noted:

$\checkmark$ Engineering of the informational and process connectivity of organizations and systems has been included in EE for a long time. During the past two decades EE concepts have been recorded in the interoperability standards [31], but the problems with operability of methods of these concepts implementation require conducting further R\&D;

$\checkmark$ The reports [27] and [28] highlight the problems and risks of a non-technological nature in the engineering of ecosystems with active users, and this requires research and inclusion of risk management concepts for both these risks and those that are not yet known in EE.

\section{Evaluation of the classical EE paradigm operability and the nature of its development}

\subsection{Operability of the classical EE paradigm}

Two main DT areas highlighted above are development of classic production operations and new types of information and communication results acquisition. Evaluations of sufficiently full operability of the classical EE paradigm concepts for the first mentioned area have also been formulated. It should be noted that this conclusion also spreads to such a powerful trend as Industry 4.0, where enterprise engineering is being performed with a very high level of automation and connectivity to provide a really large and obvious increase in efficiency, but, in fact, it is still carried out in the scope of classical concepts.

Earlier, a conclusion was also reached about the applicability of the EE classical paradigm for the second, relatively newer area of the DT. However, its relative novelty requires a more detailed approach to evaluation of this area and application to it of the classical EE concepts. In particular, comparative evaluation of the transformations volume within the two mentioned areas, as well as costs estimation for the modernization of the existing business processes and IT systems required for implementation of innovative solutions are useful. Precise estimates of the global volumes of work in these areas are not available, but the volume of modernization of basic production processes for the classical products and services is understood to be many times greater than the volume of purely innovative works. To support this evaluation, let us refer to the Gartner estimate for the next years prospects [32], claiming that by 2019 every dollar invested in innovations will require an additional seven dollars for the modernization of the 
core of the existing business processes and production systems.

In the longer perspective, the proportion will be changing, but traditional market capacities are conservative, and the emergence of any new species and even types of products will also require further modernization of the main processes and production systems, that is, continuation of the transformations carried out within the frame of the classical EE paradigm. Apart from that, interactions between the "traditional" and "new" enterprises (their divisions), reflected by the integration model in Figure 1 will remain. It should be noted that these interactions work within a single enterprise or between partner-enterprises (the similar conclusion is drawn in the report [26]). This means that EE paradigm should include those concepts that apply not only to the "digital leaders", but also to enterprises or parts of enterprises of various types and "digitization" levels, as well as to interactions of such different-type enterprises and their divisions.

Therefore, the global nature of the DT tasks and the level of real production operations development make it possible to forecast that in the perspective under consideration the classical EE paradigm will be operable in the vast majority of engineering cases for both areas of transformation.

\subsection{Openness and the nature of paradigm development}

Operability of the classical EE paradigm also relies on the possibility to apply in EE new concepts in parallel or even in conjunction with the classical ones, as well as to apply alternative concepts. As examples of the concepts defined already in the first decade of the 21st century, the following can be highlighted:

$\diamond$ Use (as opposed to elimination) of manifestations of general-cultural and professional multiculturalism for work enrichment (which was formulated in the paper [3]);

$\diamond$ Involvement of customers in active co-creation within an enterprise ecosystem (which was formulated and methodically provided in the papers $[27,33]$ ), as opposed to offering them only unified products (possibly with tailoring for consumer needs).

Requirements for the EE to carry out all the works with the help of strictly engineering-and-analytical methods ("technocratic concept") and the requirements to transform in the first place the human relations and philosophy of work, starting with the behavior patterns of managers ("humanitarian concept") can be mentioned as an example of the classical alternative EE concepts. Problems in practical joint application of these concepts are great enough, which requires creating additional methods for their harmonious combination, however, both of them are parts of the classical paradigm, enriching it.

There are other problems in the practice of EE application as well (in particular, a problem of the integrated ontology concept implementation and related with it an interoperability problem), a more detailed analysis of which is going to be considered in a separate publication. It is important to note that so far the problems associated with disadvantages of methods and tools for implementing concepts or lack of an adequate concept have been settled (when they could be settled) on account of the openness of EE discipline as a system. This fact has been expressed in EE's continuous expansion through new methods, tools and even concepts, which has not been restricted with the basic standards [1, 2].

Considering all aforementioned, the following answers to the first questions posed in the Introduction can be suggested:

Concepts of the classical EE remain fully operable for the majority of enterprises interacting with each other;

$\downarrow$ Within the limits of the horizon under consideration, the "picture of EE world" is undergoing expansion, but no radical change can be observed; therefore, there are no grounds to talk about the need for a new EE paradigm or a radical paradigm shift of the existing paradigm.

It is supposed that with the forecasted development of technologies and enterprises on the horizon under consideration, new operable EE concepts can continue to be used in conjunction with classical ones, as well as with their expansions. This also applies to such significantly new concepts as, for example, engineering of non-classical forms of management under high uncertainty conditions or engineering of multi-agent systems with different types of actors incorporating robots into the enterprise as its subjects. Thus, it is possible to talk about the quite specific nature of EE development, namely, about the continuously expanding EE paradigm, and a sketch of its development is shown in Table 1. In this Table, already operating new concepts that were formulated at the beginning of the 21 st century are named "Operating and relatively new concepts", and the result of inclusion of these concepts in EE is named "Extended classical EE paradigm". 
Table 1.

Expanding enterprise engineering paradigm: sketch of development

\begin{tabular}{l|c|c|c|c} 
& \multicolumn{4}{c}{ Period (roughly) } \\
\cline { 2 - 5 } & $1992-2000$ & $1995-2000$ & 2001-2010 & 2011-2016-2030 \\
\hline \multirow{2}{*}{ Set of proposed EE conceptions } & Basic EE concepts & Additional EE concepts & $\begin{array}{l}\text { Operating and relatively } \\
\text { new EE concepts }\end{array}$ & $\begin{array}{c}\text { Essentially new concepts } \\
\text { including prospective ones }\end{array}$ \\
\hline Initial state of EE paradigm & Classical EE paradigm & & \\
\hline Current operating state of EE paradigm & & $\begin{array}{c}\text { Extended classical } \\
\text { EE paradigm }\end{array}$ & \\
\hline $\begin{array}{l}\text { General behavior of EE paradigm } \\
\text { development }\end{array}$ & \multicolumn{3}{c}{ Permanently expanding EE paradigm } \\
\hline
\end{tabular}

It should be noted that many publications using words about a new paradigm or about a radical paradigm shift, which is the same, suggest in reality just variants of EE components. One more framework variant for EE [4], one more method of matching the business and IT [8], or any method or variant of tool language can be given as examples. These new EE components can claim to be expanding EE practice, but not to be changing the "picture of EE world"? The paper [34] with more thorough conclusions speaks about the necessity of a big and hard work for a new EE paradigm forming to respond to "great challenges". Besides, the paper forecasts that exploring and solving new problems can be expected by 2025. However, analysis provided in our article demonstrates that many "great challenges" mentioned in [34] might be responded to without any paradigm shift; although changing the meaning of an "enterprise" as a concept might actually require changing " $\mathrm{EE}$ world picture" in the future.

\section{Conclusion}

The period from 1992 and presumably to 2030 is characterized by the emergence of a set of new factors strongly influencing enterprises, as well as by conscious efforts to take these factors in EE into consideration. Such factors include new technological opportunities accompanied by new risks, a sharp increase in volatility and uncertainty of the enterprise environment, as well as a number of other factors. However, the nature of the purposeful creating and functioning of enterprises remains unchanged in general; the concepts of the classi- cal EE paradigm have forestalled most of the mentioned factors, and emerging new concepts can be applied in parallel and often in conjunction with the classical ones, even if they are alternative thereto.

Consequently, within the context of the prospects under consideration, the "picture of the EE world" is undergoing expansions and changes, but no radical paradigm shift is taking place. There exist grounds to believe that throughout the entire horizon under consideration, we are dealing with a continuously expanding EE paradigm able to take into account changes in the environment and to apply new methods and technologies. Contributing factors are both the open nature of the set of concepts in the standards and methodologies of the enterprise engineering and architecture and a high degree of gradation of changes in the inherent character of the enterprises themselves.

At the same time, certain problems are observed when applying EE concepts, and to solve these problems we need further development of those methods and tools realizing them. In addition, relevance of such new engineering concepts that have been recently related to the field of futurology is growing. In this regard, within a separate publication, it is planned to analyze the problems of applying some of the most important EE concepts, both classical and new ones, as well as to highlight areas of further R\&D for some of them.

This analysis will be also associated with defining conditions under which the transition to a truly new EE paradigm would be justified. Announcing the publication of the next portion of EE changes analysis re-

\footnotetext{
${ }^{2}$ In 2013 , the author of this paper gave way to the mainstream pressure and named the system of relevant EE principles proposed in the papers $[6,9]$ as a "new paradigm". Here this name is disavowed for the reasons discussed above. However, the content of the papers [6,9] remains still valid and constructive.
} 
sults, it can be said that these conditions are for now associated in the first place neither with technologies, nor with other new productive forces, but with changes in the productive relations that form the main characteristic features of an enterprise (for example, those related with new values for the consumer and for the enterprise).That is, forming a new EE paradigm might become objectively justified when the meaning of concepts "enterprise" and "EE" themselves changes radically. It is also important to separate the objective and subjective reasons for forming a new EE paradigm.

\section{References}

1. ISO 14258:1998(en). Industrial automation systems - Concepts and rules for enterprise models (with Cor.1:2000, p.6).

2. ISO 15704:2000(en). Industrial automation systems - Requirements for enterprise-reference architectures and methodologies (With Am.1: Additional views for user concerns. 2005, 17 p.).

3. Pedersen P.B. (2001) Multiculturalism and the paradigm shift in counselling: Controversies and alternative futures. Canadian Journal of Counselling, vol. 35, no. 1, pp. 15-25.

4. Dietz J.L.G., Hoogervorst J.A.P., Albani A., Aveiro D., Babkin E., Barjis J., Caetano A., Huysmans P., Iijima J., van Kervel S.J.H., Mulder H., Op‘t Land M., Proper H.A., Sanz J., Terlouw L., Tribolet J., Verelst J., Winter R. (2013) The discipline of enterprise engineering. International Journal of Organisational Design and Engineering, vol. 3, no. 1, pp. 86-114.

5. Telnov Yu.F. (2013) Evolyutsiya paradigmy "inzhiniring predpriyatiy" [Enterprise engineering paradigm evolution]. Proceedings of the XVI Conference "Enterprise Engineering and Knowledge Management”, 25-26 April 2013, Moscow, Russia. Moscow: MESI, pp. 294-298 (in Russian).

6. Guzik S.V., Zinder E.Z., Yunatova I.G. (2013) Novaya paradigma inzhiniringa predpriyatiya i upravlenie sootvetstviem mezhdu rabochimi protsessami i kompetentnost'yu ikh ispolniteley [New enterprise engineering paradigm and compliance management for work processes and their executors' competence]. Proceedings of the XVI Conference "Enterprise Engineering and Knowledge Management", 25-26 April 2013, Moscow, Russia. Moscow: MESI, pp. 90-100 (in Russian).

7. Zinder E.Z. (2012) Novoe v arkhitekturakh predpriyatiy i ikh IT-sistem: vozmozhnosti i riski The novel in the enterprises architectures and their systems: Opportunities and risks]. Proceedings of the 7th International Conference "Modern Enterprise Governance Technologies and Information Systems Usage Opportunities: State, Problems, Perspectives”, 30-31 March 2012, Odessa, Ukraine. Odessa: ONU, pp. 148-152 (in Russian).

8. Hinkelmann K., Karagiannis D., Thoenssen B., Woitsch R., Gerber A., van der Merwe A. (2016) A new paradigm for continuous alignment of business and IT: Combining enterprise architecture modeling and enterprise ontology. Computers in Industry, no. 79, pp. 77-86.

9. Zinder E.Z. (2014) Formirovanie sistemy ponyatiy i printsipov kak bazisa novoy paradigmy inzhiniringa predpriyatiy [Forming new system of concepts as a base of a new paradigm of enterprise engineering]. Proceedings of the XVII Conference "Enterprise Engineering and Knowledge Management”, 24-25 April 2014, Moscow, Russia. Moscow: MESI, pp. 118-126 (in Russian).

10. Stroud D.J. (2002) The impact of the new technologies - Permanent paradigm shift or transitory aberration? Interactive Marketing, vol. 4, no. 2, pp. 144-155.

11. Jackson G., Ahuja V. (2016) Dawn of the digital age and the evolution of the marketing mix. Journal of Direct, Data and Digital Marketing Practice, vol. 17, no. 3, pp. 170-186.

12. Zinder E.Z. (2008) Arkhitektura predpriyativa v kontekste biznes-reinzhiniringa. Chast' 1 [Enterprise architecture in the context of business reengineering. Part 1]. Intelligent Enterprise, no. 4, 10 March 2008, pp. 46-51 (in Russian). Available at: https://www.iemag.ru/master-class/ detail.php?ID=15745 (accessed 29 October 2016).

13. Liles D.H., Johnson M.E. Meade L. (1996) The enterprise engineering discipline. Proceedings of the Fifth Annual Industrial Engineering Research Conference, May 1996, Minneapolis, pp. 479-484.

14. Kosanke K., Nell J.G. (eds.) (1997) Enterprise engineering and integration: Building international consensus. Proceedings of ICEIMT’97 International Conference on Enterprise Integration and Modelling Technology, 28-30 October 1997, Torino, Italy. Springer-Verlag.

15. Bloom H.M. (1997) Enterprise integration - A United States view. Proceedings of ICEIMT'97 International Conference on Enterprise Integration and Modelling Technology, 28-30 October 1997, Torino, Italy. Springer-Verlag, pp. 6-19.

16. Kosanke K., Vemadaf F.B., Zelm M. (2000) Enterprise engineering and integration in the global environment. Advances in Networked Enterprises. N.Y.: Springer, pp. 61-70.

17. IFIP-IFAC Task force on architectures for enterprise integration (1999) GERAM: Generalised enterprise reference architecture and methodology. Version 1.6.3, March 1999.

18. Vernadat F.B. (1998) The CIMOSA languages. Handbook on architectures of information systems. Springer-Verlag, pp. $243-264$.

19. Chen D., Doumeingts G. (1996) The GRAI-GIM reference model, architecture and methodology. Architectures for enterprise integration. Series "IFIP advances in information and communication technology". Springer, pp. 102-126.

20. Martin J. (1995) Evolution of a species. Computerworld, vol. 29, no. 15, p. 37.

21. Martin J. (1996). Cybercorp: The new business revolution. N.Y.: Amacom (American Management Association).

22. Hammer M., Champy J. (1993) Reengineering the corporation: A manifesto for business revolution. N.Y.: Harper Business.

23. Zinder E.Z. (1996) Novoe sistemnoe proektirovanie: informatsionnye tekhnologii $i$ biznes-reinzhiniring. Chast' 3 [New system design: Information technologies and business reengineering. Part 3]. SUBD, no. 2, pp. 61-76 (in Russian).

24. Zinder E.Z. (1996) Proektirovanie baz dannykh: novye trebovaniya, novye podkhody [Database design: New requirements, new approaches]. SUBD, no. 3, pp. 10-22.

25. Timmers P. (1998) Business models for electronic markets. Electronic Markets, vol. 8, no. 2, pp. 3-8.

26. IBRD (2016) Digital dividends. World development report. International Bank for Reconstruction and Development.

27. UN (2014) United Nations e-Government survey 2014. E-Government for the future we want. N.Y.: United Nations. 
28. UN (2016) United Nations e-Government survey 2016. E-Government in support of sustainable development. N.Y.: United Nations.

29. UN (2015) Sustainable Development. Transforming our world: the 2030 Agenda for sustainable development. Available at: https://sustainabledevelopment.un.org/post2015/transformingourworld (accessed 29 October 2016)

30. Evans P.C., Gawer A. (2016) The rise of the platform enterprise (A global survey). The Center for Global Enterprise. The Emerging Platform Economy Series, no. 1 .

31. GOST R 55062-2012 (2012) Informatsinnye tekhnologii. Sistemy promyshlennoy avtomatizatsii i ikh integratsiya. Interoperabel'nost'. Osnovnye polozheniya [Information technologies. Industrial automation systems and integration. Interoperability. Basic principles]. Moscow: Standartinform (in Russian).

32. Plummer D.C., et al. (2016). Top strategic predictions for 2017 and beyond: Surviving the storm winds of digital disruption. Gartner. Available at: https://www.gartner.com/doc/3471568?ref=unauthreader\&srcId=1-6595640685 (accessed 29 October 2016).

33. Zinder E.Z., Yunatova I.G. (2016) Synergy for digital transformation: Person's multiple roles and subject domains integration. Proceedings of the Conference "Digital Transformations \& Global Society" (DTGS 2016), 23-24 June 2016, St. Petersburg, Russia. Springer International Publishing, vol. 674, pp. 155-168.

34. Lapalme J., Gerber A., van der Merwe A., Zachman J., De Vries M., Hinkelmann K. (2016) Exploring the future of enterprise architecture: A Zachman perspective. Computers in Industry, no. 79, pp. 103-113.

\section{Расширяющаяся парадигма инжиниринга предприятия³}

\section{E.3. Зиндер}

Председатель правления, НКО «Фонд поддержки системного проектирования, стандартизации и управления проектами» (Фонд «ФОСТАС»)

Адрес: 107061, г. Москва, а/я 563

E-mail: ezinder@fostas.ru

\section{Аннотация}

Характер изменений парадигмы инжиниринга предприятий (ИП) и, в первую очередь, концепций этой комплексной дисциплины важен для выбора направлений развития ИП, форм накопления знаний в данной сфере и их передачи специалистам, а также устойчивости и гибкости применения ИП на практике. Анализ этих изменений особенно важен по причине высокой турбулентности методов и технологий ИП на современном отрезке развития технологий, производственных и других отношений, а также из-за возможности трактовки частных схем и методов ИП как новой парадигмы.

Для обоснованной оценки изменений парадигмы ИП определены базовые и дополнительные концепции ИП, составившие в конце XX века классическую парадигму ИП. Изложены результаты сравнительного анализа концепций классической парадигмы ИП и задач, общих для разных предприятий до 2030 года. При этом показано, что классическая парадигма ИП сохраняет работоспособность в этой перспективе. Указывается на открытый характер совокупности концепций и методов парадигмы ИП, благодаря чему в ее состав естественным образом включаются концепции, сформулированные уже в XXI веке, а также альтернативные концепции. При этом общая «картина мира ИП» не меняется на несовместимую с прежней, но и не остается неизменной: происходит постоянное расширение парадигмы ИП за счет новых методов реализации концепций, а также новых концепций, применяемых параллельно и совместно с классическими.

Проведенный анализ позволил перейти к определению новых по существу и вновь появляющихся концепций, к предложению направлений дальнейших исследований, а также к определению условий, при которых формирование и применение действительно новой парадигмы ИП может быть оправданным.

Ключевые слова: предприятие, инжиниринг предприятия, концепция инжиниринга, информационная технология, цифровая трансформация, классическая парадигма, сдвиг парадигмы, расширяющаяся парадигма.

Цитирование: Zinder E.Z. Expanding enterprise engineering paradigm // Business Informatics. 2016. No. 4 (38). P. 7-18. DOI: $10.17323 / 1998-0663.2016 .4 .7 .18$.

\footnotetext{
${ }_{3}^{3}$ Работа выполнена в рамках проекта РФФИ 16-07-01062 «Разработка методов и средств инжиниринга предприятий на основе интеллектуальных технологий»
} 


\section{Литература}

1. ISO 14258:1998(en). Industrial automation systems - Concepts and rules for enterprise models (with Cor.1:2000, p.6).

2. ISO 15704:2000(en). Industrial automation systems - Requirements for enterprise-reference architectures and methodologies (With Am.1: Additional views for user concerns. 2005, 17 p.).

3. Pedersen P.B. Multiculturalism and the paradigm shift in counselling: Controversies and alternative futures // Canadian Journal of Counselling. 2001. Vol. 35. No. 1. P. 15-25.

4. The discipline of enterprise engineering / J.L.G. Dietz [et al.] // International Journal of Organisational Design and Engineering. 2013. Vol. 3. No. 1. P. 86-114.

5. Тельнов Ю.Ф. Эволюция парадигмы «инжиниринг предприятия» // Сборник научных трудов XVI конференции «Инжиниринг предприятия и управление знаниями» (ИП\&УЗ - 2013), 25-26 апреля 2013 г., г. Москва. М.: МЭСИ, 2013. С. 294-298.

6. Гузик С.В., Зиндер Е.З., Юнатова И.Г. Новая парадигма инжиниринга предприятия и управление соответствием между рабочими процессами и компетентностью их исполнителей // Сборник научных трудов XVI конференции «Инжиниринг предприятия и управление знаниями» (ИП\&УЗ - 2013), 25-26 апреля 2013 г., г. Москва. М.: МЭСИ, 2013. С. 90-100.

7. Зиндер Е.3. Новое в архитектуре предприятий и их ИТ-систем: возможности и риски // Сборник трудов 7-й Международной конференции «Современные технологии управления предприятием и возможности использования информационных систем: состояние, проблемы, перспективы», 30-31 марта 2012 г., г. Одесса, Украина. Одесса: ОНУ, 2012. С. 148-152.

8. A new paradigm for continuous alignment of business and IT: Combining enterprise architecture modeling and enterprise ontology / K. Hinkelmann [et al.] // Computers in Industry. 2016. No. 79. P. 77-86.

9. Зиндер Е.3. Формирование системы понятий и принципов как база новой парадигмы инжиниринга предприятий // Сборник научных трудов XVII конференции «Инжиниринг предприятия и управление знаниями» (ИП\&УЗ - 2014), $24-25$ апреля 2014 г., г. Москва. М.: МЭСИ, 2014. С. 118-126.

10. Stroud D.J. The impact of the new technologies - Permanent paradigm shift or transitory aberration? // Interactive Marketing. 2002 . vol. 4. No. 2. P. $144-155$.

11. Jackson G., Ahuja V. Dawn of the digital age and the evolution of the marketing mix // Journal of Direct, Data and Digital Marketing Practice. 2016. Vol. 17. No. 3. P. 170-186.

12. Зиндер Е.З. Архитектура предприятия в контексте бизнес-реинжиниринга. Часть $1 / /$ Intelligent Enterprise. 2008 . № 4 (10 марта 2008 г.). С. 46-51. [Электронный ресурc]: https://www.iemag.ru/master-class/detail.php?ID=15745 (дата обращения 29.10.2016).

13. Liles D.H., Johnson M.E. Meade L. The enterprise engineering discipline // Proceedings of the Fifth Annual Industrial Engineering Research Conference, May 1996, Minneapolis. P. 479-484.

14. Kosanke K., Nell J.G. (eds.) Enterprise engineering and integration: Building international consensus // Proceedings of ICEIMT'97 International Conference on Enterprise Integration and Modelling Technology, 28-30 October 1997, Torino, Italy. Springer-Verlag, 1997.

15. Bloom H.M. Enterprise integration - A United States view // Proceedings of ICEIMT'97 International Conference on Enterprise Integration and Modelling Technology, 28-30 October 1997, Torino, Italy. Springer-Verlag, 1997. P. 6-19.

16. Kosanke K., Vemadaf F.B., Zelm M. Enterprise engineering and integration in the global environment // Advances in Networked Enterprises. N.Y.: Springer, 2000. P. 61-70.

17. IFIP-IFAC Task force on architectures for enterprise integration. GERAM: Generalised enterprise reference architecture and methodology. Version 1.6.3, March 1999.

18. Vernadat F.B. The CIMOSA languages. Handbook on architectures of information systems. Springer-Verlag, 1998. P. $243-264$.

19. Chen D., Doumeingts G. The GRAI-GIM reference model, architecture and methodology. Architectures for enterprise integration. Series "IFIP advances in information and communication technology". Springer, 1996. P. 102-126.

20. Martin J. Evolution of a species // Computerworld. 1995. Vol. 29. No. 15. P. 37.

21. Martin J. Cybercorp: The new business revolution. N.Y.: Amacom (American Management Association), 1996.

22. Hammer M., Champy J. Reengineering the corporation: A manifesto for business revolution. N.Y.: Harper Business, 1993.

23. Зиндер Е.З. Новое системное проектирование: информационные технологии и бизнес-реинжиниринг. Часть 3 // СУБД. 1996. № 2. C. 61-76.

24. Зиндер Е.3. Проектирование баз данных: новые требования, новые подходы // СУБД. 1996. № 3. С. 10-22.

25. Timmers P. Business models for electronic markets // Electronic Markets. 1998. Vol. 8. No. 2. P. 3-8.

26. Digital dividends. World development report. International Bank for Reconstruction and Development, 2016.

27. United Nations e-Government survey 2014. E-Government for the future we want. N.Y.: United Nations, 2014.

28. United Nations e-Government survey 2016. E-Government in support of sustainable development. N.Y.: United Nations, 2016.

29. Sustainable Development. Transforming our world: the 2030 Agenda for sustainable development. United Nations, 2015 [Электронный pecypc]: https://sustainabledevelopment.un.org/post2015/transformingourworld (дата обращения 29.10.2016).

30. Evans P.C., Gawer A. The rise of the platform enterprise (A global survey) // The Center for Global Enterprise. The Emerging Platform Economy Series. 2016. No. 1

31. ГОСТ Р 55062-2012. Информационные технологии. Системы промышленной автоматизации и их интеграция. Интероперабельность. Основные положения. М.: Стандартинформ, 2012

32. Top strategic predictions for 2017 and beyond: Surviving the storm winds of digital disruption / D.C. Plummer [et al.]. Gartner, 2016. [Электронный ресурc]: https://www.gartner.com/doc/3471568?ref=unauthreader\&srcId=1-6595640685 (дата обращения 29.10.2016).

33. Zinder E.Z., Yunatova I.G. Synergy for digital transformation: Person's multiple roles and subject domains integration // Proceedings of the Conference "Digital Transformations \& Global Society" (DTGS 2016), 23-24 June 2016, St. Petersburg, Russia. Springer International Publishing. 2016. Vol. 674. P. 155-168.

34. Exploring the future of enterprise architecture: A Zachman perspective / J. Lapalme [et al.] // Computers in Industry. 2016. No. 70. P. $103-113$ 


\title{
Infological models for smart commerce
}

\author{
Kirill A. Kniazev \\ Director, Netbell LLC; \\ Doctoral Student, Department of Innovation and Business in Information Technologies \\ National Research University Higher School of Economics \\ Address: 20, Myasnitskaya Street, Moscow, 101000, Russian Federation \\ E-mail: kk@netbell.ru
}

\section{Mikhail M. Komarov}

Associate Professor, Department of Innovation and Business in Information Technologies

National Research University Higher School of Economics

Address: 20, Myasnitskaya Street, Moscow, 101000, Russian Federation

E-mail:mkomarov@hse.ru

\section{Abstract}

In modern society, skills of working with information play a significant role. The influence of information in our everyday lives is rapidly increasing, while methods of data processing remain the same.

Research is being directed at problems of data processing and visualization of information, which become more popular with each year. This paper describes infological models, a new method of data visualization and information processing based on technologies of information presentation, as well as on principles of semantic networks, open data and data banks.

The technology of infological models represents a new approach to data storage and exchange which enables us to look at information processing in a new way. Based on principles of open data, semantic networks and data banks, the concept seeks to define the set of entities and relations, based on which an independent information block is displayed as a block diagram, which is easy to understand for an average user with a computer.

This work provides a brief overview of the information overload problem, describes the technology of infological models, its general principles and contains an application of mentioned methods in e-commerce using the example of knowledge bases, news portals, on-line shops, smart house and Internet of Things, with description of features and advantages, ending with an overall conclusion.

Key words: infological model, knowledge representation, smart commerce, semantics, visualization, open data, data banks, semantic networks.

Citation: Kniazev K.A., Komarov M.M. (2016) Infological models for smart commerce. Business Informatics, no. 4 (38), pp. 19-26. DOI: 10.17323/1998-0663.2016.4.19.26.

\section{Introduction}

A ccording to the Digital, Social and Mobile Report, in 2015 global network penetration exceeded $42 \%$, having increased by 7 percentage points over the previous year. Such a high rate of network penetration enables us to exchange a wealth of information, and a growing number of devices generates more and more data which we have to handle. Data will have to be managed so that the process of knowledge accumulation is not a problem. Attention is being increasingly focused on the issues of data visualization, interface intuitiveness and UI/UX design.

The denoted tendency makes network power accessible to new and inexperienced users. The technologies of semantic networks, open source data and data banks are changing the information management process. A new 
method of data visualization and information handling based on modern technologies of information representation, the philosophy of semantic networks, open data and data banks will be described within this study.

\section{Technology of infological models}

\subsection{Short description}

Infological models are a new intuitive way to visualize information which allows us to improve the perception, ergonomics and automated analysis of data through information presentation in the form of a human-readable, connected interactive graph. The technology is based on modern information and knowledge visualization methodologies and combines basic principles of semantic networks, open data and data banks.

\subsection{Implementation example 1: Events}

It is worth starting a detailed technology description with a review of a generic diagram of the infological model using the example of event sequence consisting of two subjects involved (Figure 1).

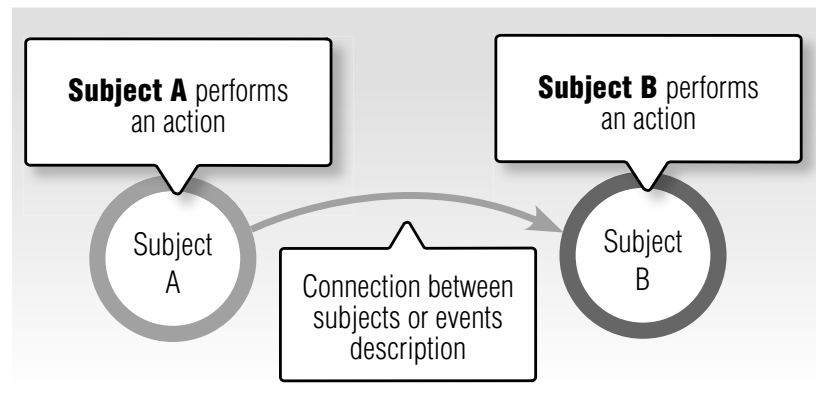

Fig. 1. Diagram of event sequence of two subjects

The left object on the diagram represents an action performed by subject $A$ which resulted in, gave rise to or transferred to the action performed by subject $\mathrm{B}$. The objective of the diagram is to outline a general narrative concept of news flow facilitating an advanced and controlled study of the information provided. Therefore, the above model not only organizes the text information, but also implements the basic principles of information visualization: a "top to bottom" approach [1], data flow control [2], model interactivity [3] and other means.

\subsection{Implementation example 2: Terms}

Let us consider the technology application using another example describing the terminology of a certain area of knowledge (Figure 2).

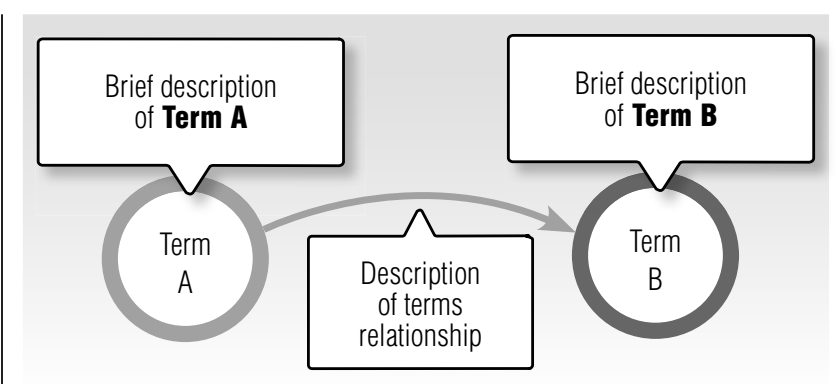

Fig. 2. Diagram of terminology with two terms

The left object in the diagram is a term describing an object in the infological model context. The right object is the second term, and the arrow in the middle also defines their relationship. The purpose of the diagram is to give us a general idea of the terminology structure and relationship of the terms, thereby placing the user into the target area of knowledge. Each term can be explained in detail by means of the model, and the user on his own is able to determine exactly which of the terms used he wants to be explained. This presentation of information not only visualizes the knowledge, but also enables the user to manage the data acquisition, moving from general concepts to more exact details.

Thus, infological models have a significant positive effect on the ergonomics of information received by the user, and so improve information handling [4, 5]. In addition, due to the micro-markup languages and serverbased parsing of the input data, an automated distribution of input data and their automatic analysis become possible, that is not only an embodiment of the semantic network, but also the implementation of the concepts described in the international data visualization research.

\subsection{System architecture}

The next figure provides an example of architecture based on which services can be deployed using infological models. A set of technologies in the framework of the architecture described is not a baseline minimum: for example, a separate server-based caching and separate databases: MS SQL and ORM-analogue, MongoDB are optional, but significantly improve the performance of the entire system (Figure 3).

\section{General principles}

Let's consider in more detail exactly what kind of principles of data handling as described in international studies can be realized through application of the technology of infological models. Within this section consideration will be given not only to engineering but also to the interface aspect of the technology. 


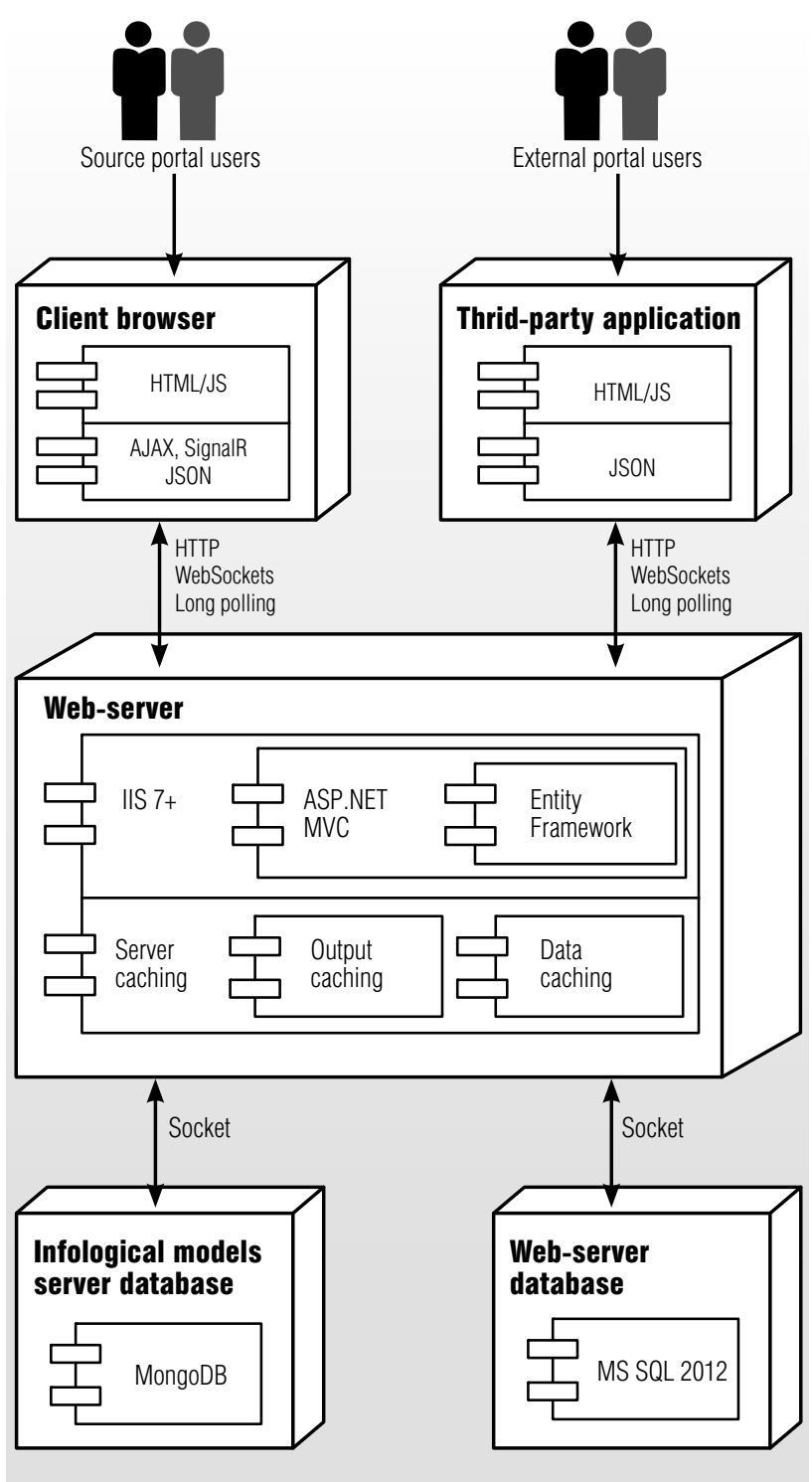

Fig. 3. Example of the system architecture

\subsection{Ergonomics}

Information visualization in infological models has its origin in the concept of semantic networks and the principles of the worldwide research (Figure 4).



Fig. 4. Changes in state pension provisions
As exemplified by the above picture, it is obvious how application of an infological model can change the approach to information perception [3]. Let us consider the example in more detail: a law approved by the Government affects social payments to pensioners and public sector employees. Thus, a person not yet familiar with the law can already observe in the diagram if he is affected by the consequences. If a user belongs to one of the categories of citizens who are subject to operation of the law, a citizen can see the changes imposed by the law on welfare payments by moving the cursor to "its" icon or caption $[4,6]$.

Eventually, instead of studying 64 pages of the full text of the law, the user will get the required amount of information from an extract consisting of several sentences.

\subsection{Interactivity}

The interactivity, as written by Alan MacEachern in his studies $[3,7]$, is one of the main tools of qualitative computer information visualization. Infological models are inherently interactive, and each model element is available for user interaction.

When hovering a cursor over the model object, the user obtains an extensive description of the event or term represented by the object. Thereby, it becomes possible not only to develop the user's behavioral pattern teaching to predictable interaction with the model, but also to control his attention, highlighting the most important terms and/or events within the model [8] (Figure 5).

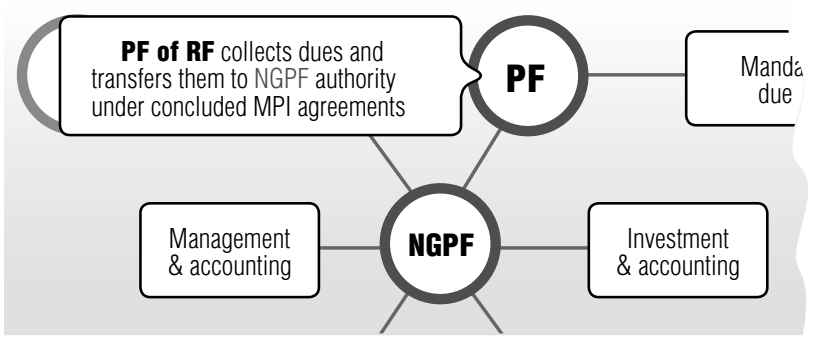

Fig. 5. Full description of the infological model's object

The example above shows a model fragment describing a reallocation of functions of the non-state pension provisions to market participants.

In addition to the general diagram representing the entire picture, hovering over the object reveals a detailed description of new features of the selected object, and also contains the link to the full description of the selected object with all the related information. Eventually, the user can first evaluate the picture as a whole, and then study the details through interaction with the model [9]. 


\subsection{Animation}

Animation is the primary way to "revive" the model and make a call for interaction addressed to the user [7]. But the most important thing is that animation makes the model narrative by default. Besides the afore-mentioned Alan MacEachren's studies, which describe the role of animation in terms of computer information visualization, we would like to pay special attention to Chris Baber's position determining the narrative nature of information by the basis of event chains [10].

The infological models are gradually shown to the user, in chronological order of occurrence of events or in hierarchical order of terms arrangement. From the first second this allows the user to understand the direction of the news flow and the order in which it is preferable to be studied (Figure 6).

As you can see by the example, the animated information output reveals the narrative aspect of infological models, records events in sequence, and above all makes it possible to control the user's attention with seemingly equivalent model objects.

\subsection{Automated information analysis}

With the help of predefined sets of stencils and information organization in the form of a semantic network, it becomes possible to analyze data automatically and accurately. Here are some examples of complicated reports which can be built automatically within the technology of infological models and applied in appropriate target areas:

$\checkmark$ activity of the President in the healthcare area during the last month;

$\checkmark$ the story of competitions and awards for any film at the cinema ceremony with referencearticles;

$\checkmark$ the share of legislators, initiated positive changes for unemployed citizens in pension market over the last year;

^ "conversional funnels" of social law enactment;

a host of other things.

166-FL "About state pension provision"

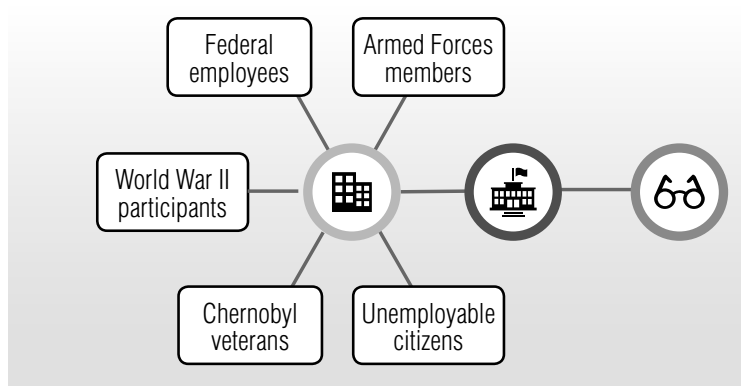

Fig. 6. Animated process of model appearance

\subsection{Automatic extraction of information fragments}

Structuring of used stencils and information systematization within the infological model make it possible to computerize not only the information analytics, but also extracts for the related articles.

Thus, for example, automatically extracted data can be placed within an article on any portal. Furthermore, owing to micro-markup languages, all information managed by the system remains accessible to search algorithms and is suitable for machine-readable use. As a result, we get export and data-sharing mechanisms for on-line services (Figure 7).

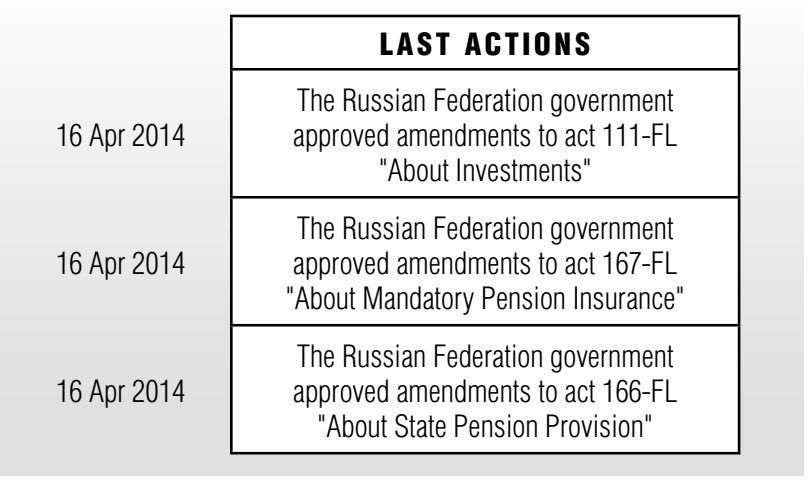

Fig. 7. Automatically formed list of Government acts

The example above reveals an automatic sampling of the latest acts of the Russian Government. Thus, provided that the base of infological models in the selected area is filled, a fully automated reporting and analysis of the subject actions described in the infological models are possible, that for the time of writing this paper is a unique feature of the solution.

\subsection{Integration with data sources}

Inasmuch as the technology of the infological models is associated with the visual methodology and notation of semantic markup, it can be integrated with the sources of dynamic data.

Moreover, the technology was developed with a longterm prospect of automated data generation: starting from uploading of the simplest news blocks from the open publishers and ending with the implementation in the smart house ecosystem, BI systems, etc. (Figure 8).

The example above shows the structural presentation of the infological models applied to a smart house. In particular, blue elements indicate the rooms which have operating devices; green elements indicate completely "switched off rooms". 




Fig. 8. Infological models in the scope of the smart house

By clicking a room, a data summary received from the connected sources is displayed and it becomes possible to go to an enlarged view of the room. In addition to information presented in the picture, interactive graphs and an enhanced navigation link can be arranged.

\section{Application of infological models in e-commerce}

Let us analyze the use of infological models as a tool of information visualization in the e-commerce environment.

\subsection{Information portals and knowledge bases}

Information visualization is a relevant task of the infological models. This makes the technology a powerful tool in the area of information portals and knowledge bases. Among the capabilities offered by the technology for information portals and knowledge bases, the most significant ones are the following:

- Data coherence. All terms and articles integrated into the system are interconnected. The models in which the content data is used are also combined into a single semantic network and available for automated analysis;

$\downarrow$ Data integrity. The data coherence determines the completeness of data provided to the user: it is easy to find descriptions of the adjacent terms, a detailed description of the term itself or a general model of the area in which the term is involved.

Dissemination of information. Infological models added with properly configured API make it possible to automate information dissemination. The peculiarity of this application consists in the coherence of information disseminated: the portal receiving data is not limited by the transmitted infological model and can provide users with a model-linked content, of course, if this is allowed by the source portal.

\subsection{News portals}

The quality of the news portal is determined not only by the quality of news articles placed therein, but also by their reliability and time of occurrence. As of today, the speed of indexing the biggest news portals by search systems takes a few minutes from the beginning of indexing before the page enters the search samples, and therefore, the issue of efficiency and control of the news source is particularly hot-bottom.

Due to the structure of the technology of the infological models, their usability can offer a number of unquestionable advantages to news portals: high quality of information visualization, promptness expansion of data dissemination, high reliability of borrowed fragments of articles, completeness of data proposed to users and possibility of automated analytics of the posted content.

The most important capabilities offered by the technology to news portals are as follows:

$\diamond$ Rapid dissemination of information. Due to automation of the process of distribution of infological models and their fragments, it becomes possible to implement a semi-automatic posting of news articles on the portal; this significantly reduces the time required for preparation of news to be posted on the agency's website;

$\diamond$ Management of information dissemination. Properly configured APIs make it possible to automate the process of information dissemination and control it by defining the access policy and data borrowing. This also makes it possible to automate the monitoring and analysis of information dissemination, all of which opens up new prospects for the news agencies;

$\diamond$ Monitoring of the datasource. Allinfologicalmodels borrowed from third party resources keep the designation of the data source, thereby facilitating monitoring of the source and tracking of the information channels.

\subsection{On-line shops}

The directory tree, its interface and service of automatic recommendations were and remain one of the key issues in the context of developing on-line shops. Due to powerful capabilities of automatic analysis of the posted information, infological models serve as powerful tools in relation to the afore mentioned problems.

In addition to the high quality of data visualization as described above, the use of infological models can bring a number of notable advantages to on-line shops: informational contents of description of goods and good categories, flexibility of the directory tree being used at the site, 
automation of handling processes for information posted on the site, powerful capabilities of automated analytics of the commodity grid and manageable data exchange.

Among the capabilities accessible for on-line shops in the course of applying the technology of infological models, three key capabilities can be identified:

- 'Smart' cross-sale modules filled based on analysis of the commodity grid and recommendations of postsales analytics. When infological models are properly configured, the recommendations of the entire sets of additional accessories can be automated.

- Updated and coherent knowledge base. The knowledge base containing recommendations on key goods categories is becoming more urgent in specialized on-line shops. Infological models can not only improve visualization, but also automate information uploads on the goods sites and filling of the bases with new data.

- Structured and controllable sales catalog. It becomes possible for on-line shop clients to use both a new access interface, and a new tree management interface for the internal employees. The change of the catalog tree can be turned into rebinding of the catalog infological model nodes to new menu items on the site.

\subsection{Smart house and the Internet of Things}

The concept of the Internet of Things is experiencing rapid growth, though the full implementation of the idea of easy management of things via the Internet causes a number of problems, principally noncooperation of the manufacturers and developers in relation to the API and interfaces used.

Due to differences in the hardware and software interfaces, it becomes impossible to create a common platform for managing things under control, and that, in turn, adversely affects the development of the area as a whole.

Application of the infological models as a means of monitoring and visualization of indicators can solve a part of the problems identified, bringing the following advantages to the Internet of Things: a high usability level, informational contents of working models, unification of the user interface to manage the things, automated monitoring and analytics of indicators, as well as a high degree of adaptability to new devices.

In the long view of using the infological models for the Internet of Things, the following significant capabilities can be identified:

$\diamond$ API for data systemization and exchange on a singlesolution platform. Since the infological models can be represented by an independent data visualization level from the Internet of Things devices, the aggregated data become available for any computerized analysis through customizable API;

\& Monitoring and analysis of indicators. The intuitive interface and high information content provide the user with a convenient tool to track aggregable indicators. In addition, data coherence and machine-reading facilitate automated analysis of the collected indicators. For example, we can determine in which room the power consumption is unreasonably high, or find out whether all electrical appliances are switched off.

By the example of the figure "Infological models in the scope of smart house," it is shown what the smart house interface built on the basis of the infological model could look like. The green color indicates low power consumption, while the blue color indicates a high power consumption. In so doing, data falling on the models are dynamic and are being updated in real time.

What happens if you go down to the next detail level of the concept, to a separate room? You can see items included in the content of a selected room and move to their management. The following example opens a view of a separate room based on the infological models interface (Figure 9).



Fig. 9. Concept of the smart house room interface

\subsection{Event logging}

In addition to the identified capabilities, a list of recorded events associated with the selected subject can be logged in a separate subject of the infological model. For example, periods of kettle operation and electricity consumption graph. The historicity of the data provided, while maintaining a high level of usability, is a distinct advantage of the technology. 
Therefore, the usability of the technology is of an extensive nature - from a point tool for e-commerce sites to a multipurpose platform combining standards and technologies. To some extent, it is due to a new approach to information visualization and consequent improved human perception of data; to some extent it is caused by information processing capabilities offered by the use of infological models in modern business areas and life.

\section{Conclusion}

During the research, modern data processing technologies and information visualization methodologies were analyzed. The results of studies and papers which have found their ways in the world scientific literature were also interpreted.

The analyzed material and the results obtained during the study provided the basis for designing and developing a technology of infological models incorporating key features of information processing and visualization. Thus, the tasks set for the research were solved, and the goal of creating a new effective method of data visualization and information handling was achieved.

Using the findings obtained during the study by the Netbell ${ }^{1}$ project team, a technology of infological mod- els with the following features was designed and implemented:

$\diamond$ high efficiency of news and data exchange;

$\diamond$ monitoring of data sources;

$\diamond$ information flow management;

$\diamond$ integrity and coherence of the data provided;

$\diamond$ automated generation of customer-focused pages;

$\diamond$ automated analytics of input information;

$\diamond$ a host of other things, depending on the area of the technology application.

The final part of the study describes the usability of infological models in e-business as seen in information portals, knowledge bases, news portals, on-line shops, the Internet of Things and smart houses, as well as the technical basis required for implementation of the technology.

It should be noted that the use of the technology of infological models is possible even today, and it offers some important challenges, i.e. improving the human perception of information, development of "smart" commerce, as well as systematization and automation of information processing.

This article is an extended version of the material presented at the IEEE Conference on Business Informatics in 2016 .

\section{References}

1. Baber C., Andrews D., Duffy T., McMaster R. (2011) Sensemaking as narrative: Visualization for collaboration. Proceedings of the Third International UKVAC Workshop on Visual Analytics (VAW 2011), 7-8 September 2011, University College London, UK, pp. 7-11.

2. Baber C., Andrews D. (2014) Visualizing interactive narratives: Employing a branching comic to tell a story and show its readings. Proceedings of the 32nd Annual ACM Conference on Human Factors in Computing Systems (CHI 2014), 26 April - 01 May 2014, Toronto, Canada, pp. 1895-1904.

3. MacEachren A.M., Monmonier M. (1992) Geographic visualization: Introduction. Cartography and Geographic Information Science, no. 19, pp. 197-200.

4. Averbukh V.L. (2006) Metafora interfeysa i metafora vizualizatsii. Kakaya teoriya nam nuzhna? [Interface metaphor and visualization metaphor. Which theory do we need?]. Proceedings of the 16th International Conference on Computer Graphics and Applications (GraphicCon 2006), 1-5 July 2006, Novosibirsk, Russia, pp. 262-268 (in Russian).

5. Averbukh V.L., Bakhterev M.O., Baydalin A.Yu., Gorbashevskiy D.Yu., Ismagilov D.R., Kazantsev A.Yu., Nebogatikova P.V., Popova A.V., Vasev P.A. (2008) Searching and analysis of interface and visualization metaphors. Human computer interaction: New developments, K. Asai (Ed.). Available at: http://www.intechopen.com/books/human_computer_interaction_new_developments/searching_and_analysis_of_interface_and_visualization_metaphors (accessed 01 September 2016).

6. Segel E., Heer J. (2010) Narrative visualization: Telling stories with data. Visualization and Computer Graphics, IEEE Transactions, vol. 16, no. 6, pp. 1139-1148.

7. MacEachren A.M. (1995) How maps work: Representation, visualization, and design. N.Y.: Guilford Press.

8. Cooper A. (2004) The inmates are running the asylum: Why high-tech products drive us crazy and how to restore the sanity. Indianapolis: Sams Publishing.

9. Bier E.A., Card S.K., Bodnar J.W. (2008) Entity based collaboration tools for intelligence analysis. Proceedings of IEEE Symposium on Visual Analytics Science and Technology (IEEE VAST '08), 19-24 October 2008, Columbus, Ohio, USA, pp. 99-106.

10. Noyes J., Baber C. (1999) User-centred design of systems. Springer Verlag.

${ }^{1}$ Information on the developer is available at http://netbell.ru 


\title{
Инфологические модели для умной коммерции
}

\author{
К.А. Князев \\ директор компании «Нетбелл»; \\ аспирант кафедры инноваций и бизнеса в сфере информационных технологий \\ Национальный исследовательский университет «Высшая школа экономики» \\ Адрес: 101000, г. Москва, ул. Мясницкая, д. 20 \\ E-mail: kk@netbell.ru
}

\section{M.M. Комаров}

кандидат технических наук, доцент кафедры инноваций и бизнеса в сфере информационных технологий Национальный исследовательский университет «Высшая школа экономики»

Адрес: 101000, г. Москва, ул. Мясницкая, д. 20

E-mail:mkomarov@hse.ru

\begin{abstract}
Аннотация
В современном обществе навыки работы с информацией играют ключевую роль, растет влияние информации на развитие общества. В последнее время стремительно увеличиваются объемы генерируемой информации, однако методы ее обработки остаются прежними.

Исследование посвящено проблемам обработки и визуализации информации, с каждым годом приобретающими все большую популярность. Цель работы - разработать новый метод визуализации данных и работы с информацией на основе технологий представления информации, а также принципов семантических сетей, открытых данных и банков данных.

Технология инфологических моделей представляет собой новый подход к хранению и обмену данными, позволяющий взглянуть на работу с информацией с новой стороны. Базируясь на принципах открытых данных, семантических сетей и банков данных, концепция решения заключается в том, чтобы определить набор субъектов и связей, на базе которых можно отображать отдельный информационный блок в виде блоксхемы (графа), понятного как рядовому пользователю, так и компьютеру.

Работа содержит краткий обзор проблемы избытка информации, описывает технологию инфологических моделей и ее основополагающие принципы, содержит анализ использования инфологических моделей в электронной коммерции на примере применения при организации баз знаний, новостных порталов, Интернет-магазинов, умных домов и Интернета вещей. Также описываются ключевые особенности и преимушества решения с выводами на базе проведенного исследования.
\end{abstract}

Ключевые слова: инфологические модели, представление знаний, умная коммерция, семантика, визуализация данных, открытые данные, банки данных, семантические сети.

Цитирование: Kniazev K.A., Komarov M.M. Infological models for smart commerce // Business Informatics. 2016. No. 4 (38). P. 19-26. DOI: 10.17323/1998-0663.2016.4.19.26.

\section{Литература}

1. Baber C., Andrews D., Duffy T., McMaster R. Sensemaking as narrative: Visualization for collaboration // Proceedings of the Third International UKVAC Workshop on Visual Analytics (VAW 2011), 7-8 September 2011, University College London, UK. 2011. P. 7-11.

2. Baber C., Andrews D. Visualizing interactive narratives: Employing a branching comic to tell a story and show its readings // Proceedings of the 32nd Annual ACM Conference on Human Factors in Computing Systems (CHI 2014), 26 April - 01 May 2014, Toronto, Canada. 2014. P. $1895-1904$.

3. MacEachren A.M., Monmonier M. Geographic visualization: Introduction//Cartography and Geographic Information Science. 1992. No. 19. P. 197-200.

4. Авербух В.Л. Метафора интерфейса и метафора визуализации. Какая теория нам нужна? // Proceedings of the 16th International Conference on Computer Graphics and Applications (GraphicCon 2006), 1-5 July 2006, Novosibirsk, Russia. 2006. P. 262-268.

5. Searching and analysis of interface and visualization metaphors. V.L. Averbukh [et al.] // Human computer interaction: New developments / K. Asai (Ed.). 2008. [Электронный ресурc]: http://www.intechopen.com/books/human_computer_interaction_new_developments/searching_and_analysis_of_interface_and_visualization_metaphors (дата обращения 01.09.2016).

6. Segel E., Heer J. Narrative visualization: Telling stories with data // Visualization and Computer Graphics, IEEE Transactions. 2010. Vol. 16. No. 6. P. 1139-1148.

7. MacEachren A.M. How maps work: Representation, visualization, and design. N.Y.: Guilford Press, 1995.

8. Cooper A. The inmates are running the asylum: Why high-tech products drive us crazy and how to restore the sanity. Indianapolis: Sams Publishing, 2004.

9. Bier E.A., Card S.K., Bodnar J.W. Entity based collaboration tools for intelligence analysis // Proceedings of IEEE Symposium on Visual Analytics Science and Technology (IEEE VAST '08), 19-24 October 2008, Columbus, Ohio, USA. 2008. P. 99-106.

10. Noyes J., Baber C. User-centred design of systems. Springer Verlag, 1999. 


\title{
Application of the adaptive content concept for an e-learning resource
}

\author{
Dmitry A. Aldunin \\ Doctoral Student, Department of Innovation and Business in Information Technologies \\ National Research University Higher School of Economics \\ Address: 20, Myasnitskaya Street, Moscow, 101000, Russian Federation \\ E-mail:daldunin@hse.ru
}

\begin{abstract}
Nowadays, the e-learning market is rapidly growing both financially and geographically. More and more often, e-learning resources involve a multicultural audience and are becoming available to people with different educational backgrounds. However, there are cognitive specificity and different approaches to the learning process in different cultures. This paper is devoted to illustrating a possible solution for adaptation of content of an e-learning resource to a multicultural audience. The solution described applies the adaptive content concept based on individual educational trajectories and preparing content according to the individual cultural characteristics of learner and his or her competencies, both obtained and desired.

During the research, the learner-centric model of learning processes was developed. In the article, both high-level and detailed models are presented. Principles of planning the individual learning trajectory based on the learner's obtained and desired competencies, and statistical data about his or her learning style are also described. As an example of the possibility to apply historical data on how learning style affects successful passing through the learning course, the statistical analysis is provided. The analysis relies on person-course deidentified dataset from seven courses on HarvardX and MITx platforms provided during the 2013/14 academic year. This analysis demonstrated the statistical significance of several parameters. A comparison of algorithms for estimating the probability of successfully passing the course depending on the learning style, is also presented.
\end{abstract}

Key words: e-learning, cross-cultural context, mathematical modeling, web-development, individual learning trajectory, learning analytics.

Citation: Aldunin D.A. (2016) Application of the adaptive content concept for an e-learning resource. Business Informatics, no. 4 (38), pp. 27-34. DOI: 10.17323/1998-0663.2016.4.27.34.

\section{Introduction}

$\mathrm{N}$ owadays, the cross-cultural problem is one of the basic things to consider when creating an eresource focused on representatives of different cultures. Since the advent of using information technology for delivery of information, new tools and methods to present it have appeared. Some of them both partly decrease and increase the psychological tension of the process of acquiring knowledge. According to G. Uzilevsky [1], ergonomic semiotics is a scientific practice which studies the problems common to semiotics, linguistics and ergonomics, and is able to resolve a number of problems associated with the need to make information intelligible to the target audience, depending on the cognitive specificity caused by cultural differences. In the era of the worldwide Internet's intromission into most areas of life, the implementation of cross-cultural aspects of ergonomic semiotics is very important.

On the one hand, the content of usual e-resources certainly embodies the national culture of its creators [2]. On the other hand, content must meet the cultural and pragmatic expectations of the learner for maximal efficiency of presenting information. For example, it is possible to observe that Western educational content is characterized by openness, clear logic and predictability, its dosage of information and no hidden content; while Eastern content usually has a complex structure and is very context-related [2]. 
Pragmatic factors must necessarily be taken into account during the process of creating and monitoring resources aimed at a multicultural audience. There are different cognitive models of perception and processing of information in the Eastern (collectivistic and inclined to dialectic) cultures and the Western (individualistic and inclined to formal logic) cultures. In the West, the information is mostly directly perceived through the prism of the person's individual perception and is superimposed on the existing information background. In the East, users simply collect information without personal critical reflection when consuming information content [2].

\section{Basis of cultural classification}

The central object of my adaptive content concept is the learner's profile consisting of two parts: cultural and cognitive, plus competency profiles. The cultural and cognitive profile contains information about culture-related features: cognitive specificity, specificity of train of thought, and affective differences. According to M. Kholodnaya's research [3], the cognitive style reflects the way of perceiving, analyzing, structuring and categorizing the world, the style of learning. The competency profile contains a list of the learner's knowledge and skills, and the vector of his or her educational and professional development (what he or she is interested in for further learning).

It makes sense to base the cultural and cognitive profile on the six cultural dimensions invented by Geert Hofstede
[4, 5] (Power Distance (PDI), Collectivism vs Individualism (IND), Masculinity vs Femininity (MAS), Uncertainty Avoidance (UAV), Long-term vs. Short-term orientation (LTO), Indulgence versus Restraint (IVR)) because there a test exists which provides an exact value for each dimension, making it very convenient for programming. This basis was used when mapping with the cultural classifications of F. Trompenaars [6], H. Triandis [7] and R. Lewis [8]. While Hofstede's classification was driven by an individual's associates, other classifications are more individual and thus complement the former. The profile may also be extended with the binary classification of learning styles introduced by R. Felder and L. Silverman [9]. In this model, learning styles are described as a value between pairs of extremes: active or reflective, sensing or intuitive, verbal or visual, and sequential or global. There also is the test for getting values for a specific learner [10].

The competency profile should be based on a competency classificatory. Competencies should be divided into systematic competencies (core competencies, such as time-management, statistics analyzing, working in group, etc.) and professional competencies (related to the exact professional field). Professional competencies should themselves be divided in two: instrumental competencies, and social and personal competencies. The latter competency group is related to the cultural and cognitive profile and that is how connection between profiles is carried out.
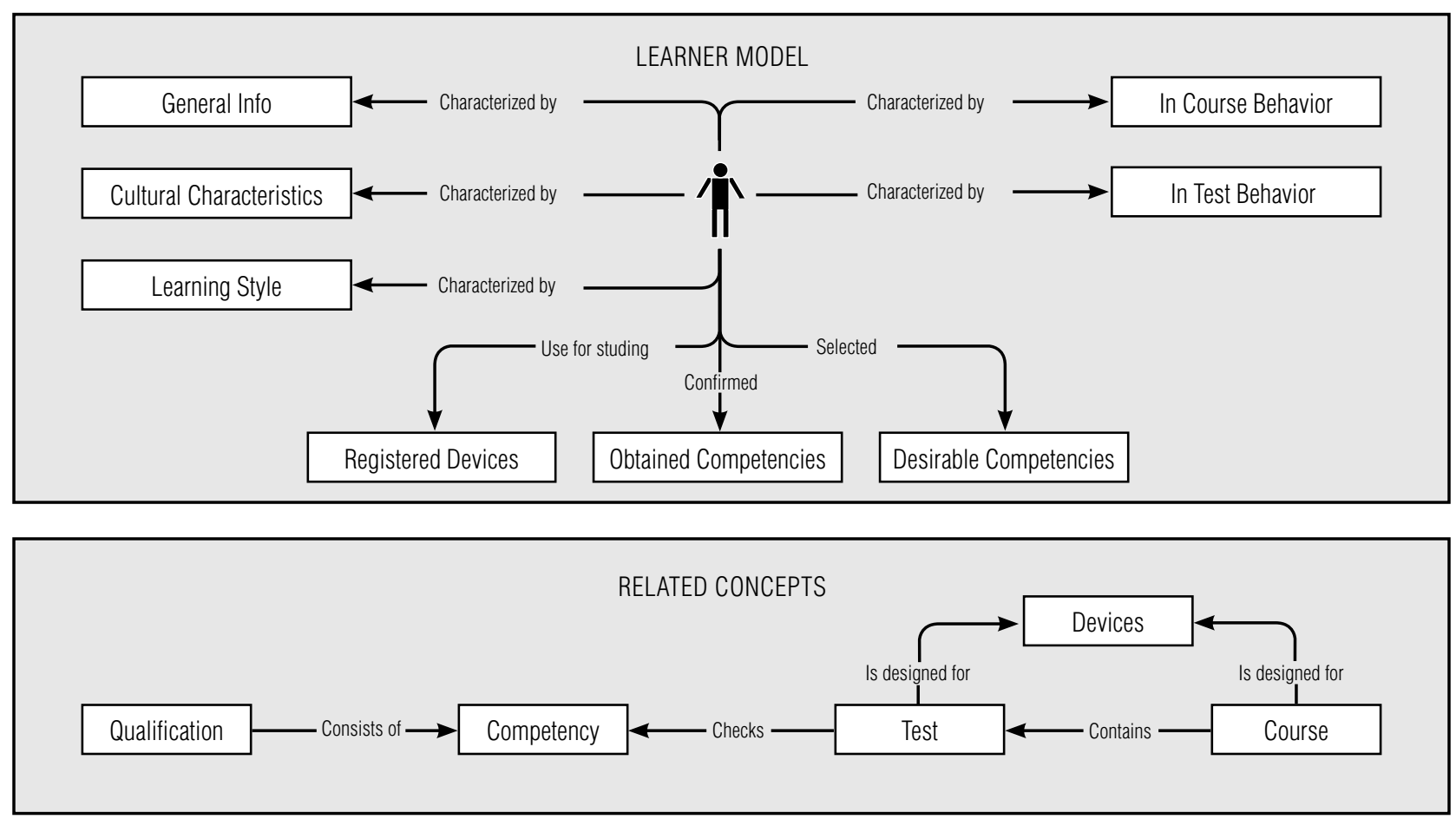

Fig. 1. Learner-centric ontology 




Fig. 2. Detailed model with attributes and relations of entries

\section{Learner's model}

Lots of models for the learner and learning process were presented by different researchers. For example, domain ontology by P.Q. Dung, A.M. Florea designed for application in a multi-agent e-learning system [11] or the model by A. Garcia-Gabot, taking the learner's device into account [12]. But these models lack a complex view of the learner, specificity of the e-learning process, and domain modeling. The following ontology model solves this problem (Figure 1).
The full model describing the relations and attributes of entities is the following (Figure 2).

The learner-centricity of this model is strongly associated with the idea of customer centricity in today's commerce, which is the key to business maturity ${ }^{1}$. As e-learning is actually a business process with certain revenues for both sides, it is obvious that learner-centricity is an important step for general e-learning development all over the world.

\footnotetext{
1 "The journey toward greater customer centricity", Ernst \& Young LLP, 2013
} 


\section{Individual learning trajectory}

An individual educational trajectory (IET) - the plan of study, taking into account preferences of the learner in the final set of acquired competences, as well as his penchant for specific forms of presentation of cognitive objects and tasks, the different methods of research and forms of expressing ideas depending on the conditions of cultural and personal characteristics. The learner should select learning courses or desired competencies for building the IET. Every course may be characterized by a set of competencies according to the competency classificatory mentioned before, the duration and price. Moreover, the duration of some courses may depend on the specific learner and the time to obtain the same competency also varies in different courses. In addition, qualifications (sets of competencies) may be formed. Therefore, when a learner, for example, selects the qualifications of an IT business analyst it means he should get a number of competencies (business process analysis, system analysis, process modeling, etc.) and a list of required courses may be formed. There are different ways to form this list: minimize the number of courses, minimize the duration, minimize the price, etc. The learner should also have the option to select courses him or herself.

Thus, it is possible to base the mathematical model on the goal of obtaining a set of $n$ competencies in $m$ courses. For each competency comp there is a set of courses which provide that competency $\left\langle c_{1}, \ldots c_{i}\right\rangle, 1 \leq i \leq m$; and vice versa, for each course there is a list of competencies it provides $\left\langle\right.$ postcomp $_{1}, \ldots$, postcomp $\left.p_{i}\right\rangle, 1 \leq i \leq n$. Moreover, for each course there are lists of pre-requisite competencies $\left\langle\right.$ precomp $_{1}, \ldots$, precomp $\left._{i}\right\rangle, 1 \leq i \leq n$.

For each course there is a value $0 \leq h \leq 1$, which defines the difficulty of passing this course depending on the share of required pre-requisite competencies for this course having been obtained before the start.

Times required for obtaining competencies may be defined as

$$
T=C T \cdot(\mathbb{1}-H)
$$

where $T=\left[\begin{array}{c}T_{1} \\ \ldots \\ T_{m}\end{array}\right]-$ time for passing courses;

$C T=\left[\begin{array}{c}C T_{1} \\ \ldots \\ C T_{m}\end{array}\right]-$ common time for passing courses;
$H=\left[\begin{array}{c}H_{1} \\ \ldots \\ H_{m}\end{array}\right]-$ difficulty of courses.

The total time of passing all the required courses depends on the limit of courses to study at once, and the sequence of courses. And as soon as the total time depends on how prepared a learner is for each course, maximization of cross-usage of competencies by learning courses is a perfect way to determine their sequence and minimize the total time. This means that competencies provided by one course should be used by another one and so on whenever possible.

The total price of studying the courses depends on the total time because of the fixed costs per unit time (FC) like payment for an Internet connection, device amortization, etc.:

$$
P R_{\text {Total }}=\sum_{i=1}^{m} P R+F C \cdot T_{\text {Total }},
$$

where $P R=\left[\begin{array}{c}P R_{1} \\ \ldots \\ P R_{m}\end{array}\right]-$ prices of courses.

Knowing the cultural specificity of a learner makes it possible to predict probable difficulties during a given course and even the probability of successfully passing an exam. Prediction of probable difficulties is possible because of:

$\checkmark$ analysis of whether the learner has required competencies;

$\checkmark$ analysis of correlations between the learner's cultural specificity and required competencies;

$\downarrow$ analysis of how learners with similar cultural characteristics passed this course exam;

$\downarrow$ analysis of which learner's behavior correlates with successfully passing courses.

As an example of the last type of analysis, several courses from combined HarvardX and MITx personcourse academic year 2013 de-identified dataset ${ }^{2}$ were analyzed using linear regression with the behavior parameters listed above. In Table 1, the listed regression coefficients define which behavior patterns are more or less important for passing the course. All of them have p-value below 0.05 , which means that all coefficients are statistically valuable. The coefficient of determination $\left(R^{2}\right)$ defines which percent of the results may be explained by the model.

Such analysis allows us to directly support learners having probably the wrong learning style or at least to inform them about possible problems and their reasons.

${ }^{2}$ https://dataverse.harvard.edu/dataset.xhtml?persistentId=doi:10.7910/DVN/26147 
Table 1.

Regression analysis of behavior leading to successful passing courses

\begin{tabular}{r|c|c|c|c|c}
\hline Introduction to Solid State Chemistry & 0.81 & 0.479 & $\begin{array}{c}\text { Number } \\
\text { of interac- } \\
\text { tions } \\
\text { with course }\end{array}$ & $\begin{array}{c}\text { Number } \\
\text { of days of } \\
\text { activity }\end{array}$ & $\begin{array}{c}\text { Number } \\
\text { of video } \\
\text { views } \\
\text { of course } \\
\text { ohapters } \\
\text { studied }\end{array}$ \\
\hline Introduction to Computer Science and Programming & 0.78 & 0.370 & 0.406 & -0.162 & 0.42 \\
\hline Introduction to Biology & 0.75 & 0.814 & 0.173 & -0.328 & 0.164 \\
\hline Electricity and Magnetism & 0.82 & 0.676 & 0.341 & -0.243 & -0.007 \\
\hline Mechanics Review & 0.84 & 0.467 & 0.050 & -0.043 & -0.005 \\
\hline Health in Numbers & 0.74 & 0.624 & 0.070 & -0.295 & -0.006 \\
\hline Human Health and Global Environmental Change & 0.67 & 0.793 & 0.031 & -0.286 & 0.017 \\
\hline
\end{tabular}

\section{Adaptation of learning content}

A learning course may be represented as a number of learning materials (multimedia or text documents). Every learning material should be divided into blocks. The block is an atomic part of learning material which should be marked by the most suitable ranges of Hofstede's cultural dimensions (one, two or even all six dimensions for very specific content) and index within material. Such a concept allows us to construct the most viable variant of learning material for a given learner. For example, if we describe the case of a company's success, the personal impact of a great leader may be focused for individualists, while statistical data may be focused for those who avoid uncertainty, etc. When the learner opens a document, it should be prepared by selecting the most suitable block for each index value or the default if no suitable block is found.

Moreover, the learning material representation interface may be adapted, too. There are five key points for such adaptation [9]:

$\diamond$ metaphors - typical images used in design;

$\diamond$ mental models - models of real life trains of thought, the use of which is stimulated when using the site;

$\diamond$ navigation - features of moving within web pages and between them;

$\diamond$ interaction - specificity of human-computer interaction;

$\diamond$ appearance - design features: colors, shapes, layout, sounds, the use of multimedia, etc.

Adaptation on most of these points may be automated. For example, computer vision algorithms (such as Cap-
tionBot powered by Microsoft Cognitive Services) allow us to automatically describe pictures.

\section{Mathematical models and algorithms}

Application of the adaptive content concept requires some mathematical models and algorithms. The first task that must be solved is how to predict the possibility of successfully completing the course.

For solving this task, it is possible to use historical data on how learners with different values on cultural dimensions passed the given course exams. Logistic regression may be used for analysis of such panel data. The binary logistic model is used to estimate the probability of a binary response based on independent predictor variables:

$$
\mathbb{P}\{y=1 \mid x\}=F\left(x_{1}, x_{2}, \ldots, x_{n}\right), y \in\{0,1\} .
$$

In this case, the binary response is success or failure in a course. Analyzing the statistics of previous students, it is possible to discover how important different parameters are for success in a particular course and use the measures of this importance (regression coefficients $\theta$ ) multiplied by values for current student $x$ to predict his result. The logistic function (or sigmoid) is:

$$
F=\frac{1}{1+e^{-\Theta^{T} x}}=\frac{1}{1+e^{-\left(\Theta_{1} x_{1}+\Theta_{2} x_{2}+\ldots+\Theta_{n} x_{n}\right)}} .
$$

Regression coefficients should be identified for every course using historical data about course completion as a training set. From the machine time cost point of view, it makes no sense to recalculate regression coefficients after getting the result for every new student, since its impact will be very low. For example, the HarvardX and 
MITx de-identified dataset of academic year $2013^{3}$ contains more than 640,000 entries (each represents one individual's activity in one edX course) for only 13 learning courses.

The next task is sequencing of courses. As was mentioned before, this algorithm should be based on maximizing cross-usage of competencies by learning courses. The depth-first traversal is the most appropriate algorithm for this task. It may build an optimal sequence from the list of courses and competencies they require and provide. The advantages of this algorithm are simplicity and avoiding the non-optimality of usual search.

The last top-tier task is forming groups of students with similar characteristics. This process may have different goals: from forming the exact number of groups within one course to forming groups according to one or several characteristics. For different goals, it makes sense to use different clustering algorithms such as K-Means, DBSCAN or Mean shift. Full descriptions of the algorithms may be found, for example, in [13].

\section{K-means clustering}

This method of vector quantization aims to partition $\mathrm{n}$ observations $\left(x_{1}, x_{2}, \ldots x_{n}\right)$ into $k \leq n$ clusters $S=\left\{S_{1}, S_{2}, \ldots S_{n}\right\}$ based on the nearest mean:

$$
\arg \min _{S} \sum_{i=1}^{k} \sum_{x \in S_{i}}\left\|x-\mu_{i}\right\|^{2}
$$

where $\mu_{i}$ is the mean of points in $S_{i}$.

\section{Advantages:}

1. K-means clustering is NP-hard problem, however, there are efficient heuristic algorithms. That makes $\mathrm{K}$-means faster than most of other clustering algorithms.

Disadvantages:

1. K-means clustering requires pre-defined number of clusters.

2. K-means clustering has strong sensitivity to outliers and noise.

3. K-means clustering doesn't work well with a noncircular cluster shape.

\section{DBSCAN (Density-based spatial clustering of applications with noise)}

This algorithm groups points that are packed in space closely (have many neighbors), marks points that lie alone as outliers (low-density, nearest neighbors are too far away). DBSCAN is one of the most cited in scientific literature ${ }^{4}$.

\section{Advantages:}

1. DBSCAN does not require a pre-defined number of clusters, opposing to k-means.

2. DBSCAN is able to find clusters of any form.

3. DBSCAN is robust to outliers.

4. DBSCAN requires only two parameters ( $\varepsilon$ and the minimum number of points required to form a dense region) and nearly ignores the order of entries being analyzed.

Disadvantages:

1. DBSCAN is not entirely deterministic

2. The scale and data must be well understood to correctly choose a meaningful distance threshold $\varepsilon$.

\section{Mean shift (mode-seeking algorithm)}

This algorithm is a non-parametric feature-space analysis approach for using discrete data for locating the maxima of a density function, from which the data was sampled. The mean shift algorithm is iterative and starts with an initial estimate $x$ :

$$
m(x)=\frac{\sum_{x_{i} \in N(x)} x_{i} K\left(x_{i}-x\right)}{\sum_{x_{i} \in N(x)} K\left(x_{i}-x\right)},
$$

where $K$ is the weighted mean of the density in the window;

$N(x)$ is the neighborhood of $x$ (a set of points for which $K(x) \neq 0)$.

The difference $m(x)-x$ is actually called a mean shift.

Advantages:

1. The mean shift does not require a pre-defined number of clusters, opposing to k-means.

2. The mean shift is able to find clusters of any form.

3. The mean shift requires only one parameter (the size of the window).

4. The mean shift is well adapted for using a Gaussian kernel.

Disadvantages:

1. Selection of a window size for the mean shift algorithm is not trivial.

\footnotetext{
${ }^{3}$ https://dataverse.harvard.edu/dataset.xhtml?persistentId=doi:10.7910/DVN/26147

${ }^{4}$ DBSCAN is on rank 41 within most cited data mining articles according to Microsoft academic search,

when accessed on: 21.08.2016
} 
Turning to the technical part, it is important to note that a database is preferable for such service rather than data storage, because the main type of queries will be selection, not insertion of entries. Integration with existing information systems (such as learning management systems of universities, etc.) may be realized via mediating the replication layer and table triggers. Thus, any change in one system may be replicated in a number of tables of the other system. This makes it possible not to adapt the service database's structure for every integration.

\section{Conclusion}

Application of the adaptive content concept in the described way may significantly improve an e-learning process:

$\downarrow$ increase the apprehensibility of learning materials. The process of e-learning does not provide such tutor support as full-time education does; it is mostly an autodidactic process. Thus, it is very important to decrease the psychological tension caused by feeling alone, having an uncertain interface and unintelligible learning materials;

$\checkmark$ possibility to build an individual educational trajectory; possibility to form the learner's competency profile. Such a profile is also useful because, in fact, it is a readyto-use part of the CV.

Further problems to study are the following:

$\diamond$ the need to prioritize the cultural dimensions during formation of learning materials in the case of mixed cultures (such as Chinese students studying in the USA for a long time) and, consequently, the development of a system of weighted coefficients;

$\diamond$ problems related to differentiation of cultural groups in the target audience (collaboration of representatives of different groups, etc.);

$\diamond$ the need to monitor the user's satisfaction and to make a forecast of changes in the user's preferences on the basis of data about users with similar parameters.

This publication is part of a series of works devoted to the analysis of conformity of cultural specificity of target audience and methods of content and design adaptation needed to ensure maximum comfort and ease of the e-learning process for this audience. The result of the entire work will be the development of a software environment that facilitates the preparation and demonstration of content sensitive to cultural specificity.

\section{References}

1. Uzilevsky G.Y. (2000) Nachala ergonomicheskoy semiotiki [Beginnings of ergonomic semiotics]. Orel: ORAGS (in Russian).

2. Huang K.-H., Deng Y.-Sh. (2008) Social interaction design in cultural context: A case study of a traditional social activity. International Journal of Design, no. 2, pp. 81-96.

3. Kholodnaya M.A. (2004) Kognitivnye stili. O prirode individual'nogo uma [Cognitive styles. On the nature of an individual mind]. St. Petersburg: Piter (in Russian).

4. Hofstede G. (1980) Culture's consequences: International differences in work related values. Beverly Hills, CA: Sage Publications.

5. Hofstede G., Hofstede J.G., Minkov M. (2010) Cultures and organizations: Software of the mind. N.Y.: McGraw-Hill.

6. Trompenaars F., Hampden-Turner C. (2004) Managing people across cultures. London: Capstone Publishing.

7. Triandis H. (2011) Culture and self-deception: A theoretical perspective. Social Behavior and Personality, no. 1, pp. 3-14.

8. Lewis R. (2006) When cultures collide. Managing successfully across cultures. Boston, London: Nicholas Brealey International.

9. Felder R.M., Silverman L.K. (1988) Learning and teaching styles in engineering education. Engineering Education, no. 7 (78), pp. 674-681.

10. Soloman B.A., Felder R.M. (2016) Index of learning styles questionnaire. North Carolina State University. Available at: http://www.engr.ncsu. edu/learningstyles/ilsweb.html (accessed 01 September 2016).

11. Dung P.Q., Florea A.M. (2013) Adaptation to learners' learning styles in a multi-agent e-learning system. Internet Learning, no. 1, pp. 11-20.

12. Garcia-Gabot A. (2013) A proposal of a multi-agent system for adapting learning contents to user competencies, context and mobile device. Research paper. Bratislava: Slovak University of Technology.

13. Gan G., Ma C., Wu J. (2007) Data clustering: Theory, algorithms, and applications. Philadelphia: SIAM. 


\title{
Применение концепции адаптивного контента для электронного образовательного ресурса
}

\author{
Д.А. Алдунин \\ аспирант кафедры инноваций и бизнеса в сфере информационных технологий \\ Национальный исследовательский университет «Высшая школа экономики» \\ Адрес: 101000, г. Москва, ул. Мясницкая, д. 20 \\ E-mail:daldunin@hse.ru
}

\section{Аннотация}

В настоящее время рынок электронного обучения быстро растет как в финансовом, так и в географическом плане. Электронные образовательные ресурсы все чаще привлекают мультикультурную аудиторию, становятся доступны для людей с различным уровнем образования. В то же время в различных культурах существует своя специфика восприятия информации и различные подходы к образовательному процессу. Данная работа посвящена иллюстрации возможного решения для адаптации контента электронного образовательного ресурса для мультикультурной аудитории. Описанное решение основано на применении концепции адаптивного контента для построения индивидуальной образовательной траектории и подготовки контента в соответствии с индивидуальными культурными особенностями обучающихся и его компетенциями (имеющимися и желаемыми).

В ходе исследования была разработана модель образовательного процесса, ориентированная на конкретного обучающегося. В статье представлены как модель верхнего уровня, так и детализированная модель. В статье также описаны основные принципы формирования индивидуальной образовательной траектории на основании имеющихся и желаемых компетенций пользователя и статистических данных о его стиле обучения. В качестве демонстрации возможности применять исторические данные о том, как образовательный стиль влияет на успешное завершение курса, приведен статистический анализ данных об изучении студентами семи курсов на платформах HarvardX и MITх в течении 2013/14 учебного года, показавший статистическую значимость целого ряда параметров. Также в работе представлено сравнение алгоритмов, применимых для оценки вероятности успешного завершения курса обучающимся в зависимости от его стиля обучения.

Ключевые слова: электронное обучение, кросс-культурный контекст, математическое моделирование, веб-разработка, индивидуальная образовательная траектория, образовательная аналитика.

Цитирование: Aldunin D.A. Application of the adaptive content concept for an e-learning resource // Business Informatics. 2016. No. 4 (38). P. 27-34. DOI: 10.17323/1998-0663.2016.4.27.34.

\section{Литература}

1. Узилевский Г.Я. Начала эргономической семиотики. Орел: ОРАГС, 2000.

2. Huang K.-H., Deng Y.-Sh. (2008) Social interaction design in cultural context: A case study of a traditional social activity // International Journal of Design. 2008. No. 2. P. 81-96.

3. Холодная М.А. Когнитивные стили. О природе индивидуального ума. СПб: Питер, 2004.

4. Hofstede G. Culture's consequences: International differences in work related values. Beverly Hills, CA: Sage Publications, 1980.

5. Hofstede G., Hofstede J.G., Minkov M. Cultures and organizations: Software of the mind. N.Y.: McGraw-Hill, 2010.

6. Trompenaars F., Hampden-Turner C. Managing people across cultures. London: Capstone Publishing, 2004.

7. Triandis H. Culture and self-deception: A theoretical perspective // Social Behavior and Personality. 2011. No. 1. P. 3-14

8. Lewis R. When cultures collide. Managing successfully across cultures. Boston, London: Nicholas Brealey International, 2006.

9. Felder R.M., Silverman L.K. Learning and teaching styles in engineering education // Engineering Education. 1998. No. 7 (78). P. $674-681$.

10. Soloman B.A., Felder R.M. Index of learning styles questionnaire. North Carolina State University. [Электронный pecypc]: http://www. engr.ncsu.edu/learningstyles/ilsweb.html (дата обращения 01.09.2016).

11. Dung P.Q., Florea A.M. Adaptation to learners' learning styles in a multi-agent e-learning system // Internet Learning. 2013. No. 1. P. 11-20.

12. Garcia-Gabot A. A proposal of a multi-agent system for adapting learning contents to user competencies, context and mobile device. Research paper. Bratislava: Slovak University of Technology, 2013.

13. Gan G., Ma C., Wu J. Data clustering: Theory, algorithms, and applications. Philadelphia: SIAM, 2007. 


\title{
On business processes of computer-supported collaborative learning: A case of peer assessment system development ${ }^{1}$
}

\author{
Andrei I. Kolomiets \\ Student, Faculty of Computer Science \\ National Research University Higher School of Economics \\ Address: 20, Myasnitskaya Street, Moscow, 101000, Russian Federation \\ E-mail:aikolomiets@edu.hse.ru
}

\section{Olga V. Maksimenkova}

Senior Lecturer, School of Software Engineering

Junior Researcher, International Laboratory for Intelligent Systems and Structural Analysis

National Research University Higher School of Economics

Address: 20, Myasnitskaya Street, Moscow, 101000, Russian Federation

E-mail:omaksimenkova@hse.ru

\section{Alexey A. Neznanov}

Associate Professor, School of Data Analysis and Artificial Intelligence

Senior Researcher, International Laboratory for Intelligent Systems and Structural Analysis

National Research University Higher School of Economics

Address: 20, Myasnitskaya Street, Moscow, 101000, Russian Federation

E-mail:aneznanov@hse.ru

\begin{abstract}
Nowadays peer assessment is recognized as a crucial part of a wide range of active learning routines. Nevertheless, practitioners and educators speak of the complexity and high resource consumption for the implementation of this type of assessment. Undoubtedly, convenient software that supports peer assessment processes may substantially raise productivity of its participants.

A review of educational literature and free software shows there are several bottlenecks in the business processes of peer assessment and key user roles. First, most of the programs examined are web-based and expand a set of tools for teachers and learners by extra interfaces. Moreover, this logically creates a new branch in the learning business process. Second, there is probably no peer assessment system which allows users to attach something other than the text to be reviewed. There is a gap in the market of free peer assessment software. This paper offers a peer assessment system specification that attempts to eliminate these disadvantages in order to improve user experience and thus increase the use of information technologies in peer assessment. The specification is based on a thorough description of the peer assessment process involving complex artifacts and double-blinded peer review. Software called PASCA (peer assessment system for complex artifacts) is introduced to illustrate the specification achieved. PASCA uses habitual e-mail services and does not affect other business processes. It supports standard features like blinding and randomization, and it provides a set of original features. They contain evaluation of arbitrary artifacts, creation of complex peer review forms with their validation and scoring, and easy analysis of data from peer assessment sessions.
\end{abstract}

Key words: business process optimization, peer assessment, computer supported collaborative learning, active learning, educational software, randomization, blinding.

Citation: Kolomiets A.I., Maksimenkova O.V., Neznanov A.A. (2016) On business processes of computersupported collaborative learning: A case of peer assessment system development. Business Informatics, no. 4 (38), pp. 35-46. DOI: 10.17323/1998-0663.2016.4.35.46.

\footnotetext{
${ }^{1}$ The article was prepared within the framework of the Basic Research Program at the National Research University Higher School of Economics (HSE) and supported within the framework of a subsidy by the Russian Academic Excellence Project "5-100"
} 


\section{Introduction}

$\mathrm{F}$ ormative assessment has settled as a powerful, effective, and well-proven active learning approach in the modern world $[1,2]$. This type of assessment involves students in educational planning and provides them with criticism, which students may treat as a guideline or an algorithm in their next steps in learning. That is the reason why questions related to formative assessment are widely studied and discussed by active learning practitioners in various fields of knowledge [3-6].

Peer assessment is widely applicable to the practice of the active learning technique. It is also well known as a powerful, and probably the most popular means of formative assessment [7-9]. For the sake of clarity, in this work we define peer assessment as a learning procedure for evaluation in which students review each other's works, evaluate them according to earlier formulated criteria, and provide feedback.

In fact, formative assessment partially causes the evolution of collaborative and cooperative assessment techniques $[7,10]$ in both traditional and computer-based types of learning, such as blended and computer supported collaborative learning (CSCL). A number of peer assessment systems (PAS) were introduced in different learning management systems (LMS), e-learning and massive open online courses (MOOC) platforms. Experience of applying PASs which support users' interaction during peer assessment has been documented in a great many academic works $[3,11,12]$.

The authors have conducted a review of educational literature in order to summarize the results of these works. The review shows high interest in peer assessment from scientists and practitioners from different fields. Thus, the first group consists of educators at various levels who focus on descriptions of the peer assessment process, their validation and verification $[7,8,13]$. The second group is interdisciplinary and unites specialists who are engaged to educational software development (e.g., business analysts, programmers, designers). The specific interests of this group in the context of peer assessment are analysis of educational business processes and their optimization, software requirements specification (SRS) design and other questions of the development of PASs [14-16].

Despite the fact that business process analysis plays a great role in software construction and development especially in such complicated area as education, an explicit software requirements specification (SRS) for a PAS seems to be missing.
Actually, educational process of different levels is well studied and classified [17]. This paper aims to introduce SRS for a modern PAS, which follows from the analysis and formalization of peer assessment processes.

\section{On the place of peer assessment in educational business processes}

By now, peer assessment as a form of formative assessment has a rather short but rich history. In different countries and knowledge areas, educators have conducted experiments and described studies connected with peer assessment implementation [2], efficiency [18], scaling, etc. Being interested in PAS development, we have generalized the works suitable to collect software requirements and to understand peer assessment processes in this section.

Several review papers by the leading scientists in the field of education published between 1995 and 2015 were taken into consideration. It seems that almost all the research mentioned above has been reviewed and analyzed in detail from different points of view in these works.

In 1998, Topping [13] enriched the body of reviews about active forms of assessment with a review on peer assessment literature specialized in higher education. The review studies 109 research papers which were published between 1980 and 1996. Topping probably was the first one who systematically reviewed and generalized the results about reliability and validity of peer assessment in higher education. Unlike other reviews taken into consideration in this paper, his work underlines the significance and the necessity of participants' matching and randomization within the peer assessment process. An important requirement arises from this result. A flexible peer assessment system should implement high quality algorithms of randomization.

Dochy et al. in 1999 reviewed the quantitative studies on active forms of assessment (self and peer assessment) and covered the period from 1987 to 1998 [8]. Based on the results of analysis of more than 60 research reports, the authors suggest guidelines on self- and peer assessment. They underline the great formative role of peer assessment and the significance of clear, predefined assessment criteria. Moreover, this work draws attention to the need to provide support to students during the assessment processes. Since the work does not focus on technical details, no method of automating the support is proposed. 
A year later, in 2000, Falchikov and Goldfinch presented a meta-analysis of comparative studies conducted from 1959 to 1999 and concerned with comparison of the marks which were gained from peer-assessment and from a teacher [7]. Detailed analysis of 96 qualitative and quantitative studies confirms wide abilities of peer assessment implementation in different areas with students of different levels. In addition, the authors recommend practitioners to follow the design and the implementation reported in the study. Falchikov and Goldfinch also emphasize that only formative feedback is appropriate to peer assessment processes.

In 2010, van Zundert et al. [10] issued a complex review of peer-assessment efficiency. The review deals with 26 empirical studies selected from several databases and published between 1990 and 2007. The paper reports high psychometric quality of peer-assessment procedures and generalizes the results of studies confirming a positive correlation between peer-assessment and learning outcomes in different domains. The main advantage of the review is that van Zundert et al. approved peer-assessment applicability to courses of different specializations [19]. The paper also cited a study described the computing course integrated with a peer assessment system [6].

In the same year, Kollar and Fischer [20] introduced a review which concerned the cognitive facilities of peer assessment, and also partly described peer assessment process modeling. These results allowed us to consider that the actors of a peer assessment process are defined as an assessee and an assessor. The assessee sends his work to be evaluated, and the assessor evaluates the work received and gives a formative feedback. In PASCA, instead of assessee and an assessor we use correspondingly a submitter and a reviewer. Moreover, a student generally plays both these roles when participating in a peer assessment.

The next review valuable for our study by Nulty [9] was published in 2011. The author introduced a representative body of literature which examined peer-assessment application in first-year courses. Though Nulty does not give any practical recommendations on using peer assessment in universities, he formed an academic basis for its unhampered application to the first-year courses. This opens prospects for software adoption in first-year courses which are relatively massive.

Summarizing all of the above, we may conclude that a large amount of work has been done in the field of peer assessment investigation and implementation. The body of literature presented above has already helped us in collecting requirements and defining the roles for PASCA. As an intermediate statement, the functional requirements should include: sending and receiving feedback between participants and administrator of $\mathrm{PA}$, randomization of reviewers.

\section{Computer supported peer assessment: challenges and solutions}

Over the years, computer-based PAS have paved their way to be used in learning activities on a daily basis by different institutions. Evidently such systems have become especially popular in computer programming education. In this field, among other advantages, peer assessment familiarizes students with practices used in the profession (e.g. code inspection, reflective practice).

Generally, the most of widely spread PASs are either incorporated into utilized LMS, or web-based. These options guarantee that every participant of the PA process can easily access the system.

Most systems implement different grading algorithms based on weighting marks which are awarded from different reviewers and/or task assigner. Key differences comprise providing specific functionality, such as: anonymization; randomization; support for complex artifacts; means of communication between submitter and reviewer, feedback; conditional actions (e.g. informational messages based on deadline time or on number of acquired submissions).

Typical examples of PASs in use to date are presented in Table 1. Some of the mentioned systems are the outcomes of scientific studies that examined the PA process.

One of the first successful implementations of a computer-based PA assistant - NetBeans - was described by Lin, Liu, Yuan et al. [19]. Among software-related studies, extensive research has been carried out on practical advantages of PA during educational process.

Another example of a web-based PA assistant is SPARK. It was introduced by Freeman and McKinzie in 2002 [21]. The system focuses on group projects with an assignment evaluated by each group member.

A similar approach is found in WebPA system [15], which was developed at the Centre for Engineering and Design Education at Loughborough University. This system aims to leverage bias in reviews conducted by different students, the teacher and during selfassessment. A notable difficulty of integrating WebPA is the necessity to deploy a web-server installation to 
be accessed by PA participants. A similar installation process is required by MyPeerReview, the result of investigation described by Hyyrynen, et al. in 2010 [16]. The development was initiated due to interest in the PA process. Preliminary tests showed students' positive attitude to PAS and issues future work.

As a way to free users from server-side installation work, Hamer and colleagues designed and support the web-based system Aropä [22]. This system is ready to be used via a web-interface after registration. The system supplements education in several institutions world-wide.

Long-term research into studio-based interactive learning has led to the development of the Online Studio-Based Leaning Environment (OSBLE) introduced in 2010 by Hundhausen, et al. [14]. The study proved that PAS improve students' involvement and the efficiency of the PA process. OSBLE is specialized in source code review, specifically optimized for Visual Studio IDE interaction. This fact narrows the field of application of this.

Since the beginning of the 21 st century, user expectations concerning software have risen substantially, as has the level of technologies used in development. Thus, it is important to investigate modern solutions for developing a PAS. For instance, the well-known LMS Moodle delivers a Workshop module that assists in a PA process without the need to install extra software or even switch to another tab in the web browser.
Current solutions exhibit a high barrier to entry: in order to use a PAS, teachers almost inevitably need to contact an IT-department for a proper server installation. An LMS-based PAS lessens this problem in case LMS is already being used in the course, however even module installations may require assistance.

Although modern technologies allow embedding links to complex objects of any type using cloud services, it is very convenient to be able to exchange files right in a PAS. Moreover, means of communication are especially vital in case of double-blinded peer assessment. Table 1 allows us to compare the main properties of the solutions mentioned.

\section{Application field analysis}

\subsection{Main concepts of a peer review process}

Here we define Peer Assessment (PA) as an assessment procedure organized in the form of a randomized Peer Review (PR) of arbitrary artifacts treated as results of an assignment with previously formalized assessment criteria. The process of PA of a single assignment is called PA session. The main roles of the PA process:

1. Teacher - any organizer or manager of a PA process with full access to a PA data objects.

2. Student - any trainee who participates in a PA session.

3. Initial Author - a student who was registered as future Submitter in a PA session.

Comparative table of some obtainable PASs

Table 1.

\begin{tabular}{|c|c|c|c|c|c|c|}
\hline PAS & Ships as & Artifacts & 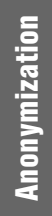 & 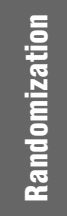 & $\begin{array}{l}\text { Communication } \\
\text { and feedback }\end{array}$ & $\begin{array}{l}\text { Extra features } \\
\text { and comments }\end{array}$ \\
\hline WebPA & $\begin{array}{l}\text { Web-based, } \\
\text { Server deployment required, } \\
\text { Open-source }\end{array}$ & $\begin{array}{l}\text { Not supported, } \\
\text { Artifact submis- } \\
\text { sion is to be held } \\
\text { externally }\end{array}$ & - & $\left.-{ }^{*}\right)$ & $\begin{array}{l}\text { Feedback, } \\
\text { Justification comments }\end{array}$ & $\begin{array}{l}\text { Intelligent algorithmic mark } \\
\text { calculation, } \\
\text { Powerful but complicated tool }\end{array}$ \\
\hline MyPeer-Review & $\begin{array}{l}\text { Web-based, } \\
\text { Server deployment required }\end{array}$ & $\begin{array}{l}\text { Submission should } \\
\text { include external } \\
\text { links }\end{array}$ & + & $?$ & $?$ & $\begin{array}{l}\text { Current development status } \\
\text { not clear }\end{array}$ \\
\hline $\begin{array}{l}\text { Moodle } \\
\text { Workshop }\end{array}$ & Moodle LMS module & Complex & + & + & Private messages & $\begin{array}{l}\text { Moodle provides wide } \\
\text { extensibility }\end{array}$ \\
\hline Aropä & Web-based & Text only & + & + & Submitter-reviewer Dialogues & Supports review of reviewers \\
\hline OSBLE+ & $\begin{array}{l}\text { Visual Studio IDE Plugin, } \\
\text { Web interface }\end{array}$ & Source Code & + & + & $\begin{array}{l}\text { Author rebuttal sessions, } \\
\text { Discussion feed }\end{array}$ & $\begin{array}{l}\text { Inline code review, Advanced } \\
\text { rubric editor }\end{array}$ \\
\hline
\end{tabular}

*) Each group member grades all other members (by design) 
4. Submitter - a student who creates an artifact and submits it to a PA session.

5. Reviewer - a student who writes a review and sends a complete PR form to a PA session.

Main PA data objects:

1. PA parameters - a set of formal parameters for current PA session.

2. PR form - a table that specifies fields in a review for some type of an artifact. Ideally, a PR form contains clear description of fields and supports basic value validation. It should also contain a text field called free comment for immediate unformalized feedback.

3. Submission - a complete artifact, submitted by a Submitter into a PAS as a result of the assignment in the current session.

4. Review - a complete PR form received from a $\mathrm{Re}$ viewer.

5. Feedback - additional information from a Student, different from Submission and Review.

Some remarks about the main concepts and terms:

1. In our case of PA, we suppose that a set of Reviewers is equal to or less than a set of Submitters in terms of sets theory. It is easy to divide these sets for other schemes of PA.

2. We use separate verbs Submit and Send/Broadcast to distinguish actions on the stage of collecting artifacts (submissions) and in several other situations.

\subsection{Business processes of a PA Session}

The five main stages of a PA session are described in Table 2. After analyzing a process of a PA session, we found phases in which automation of teacher's work can be most efficient.

Table 2.

PA session stages

\begin{tabular}{r|l|l|l} 
No. & \multicolumn{1}{|c|}{ Title } & \multicolumn{1}{c|}{\begin{tabular}{c}
\multicolumn{1}{c|}{ Initiation } \\
event
\end{tabular}} & \multicolumn{1}{c}{$\begin{array}{c}\text { Finalization } \\
\text { event }\end{array}$} \\
\hline 1. & Preparation & Create a PA session & $\begin{array}{l}\text { Complete a PA } \\
\text { session configuration }\end{array}$ \\
\hline 2. & $\begin{array}{l}\text { Collecting } \\
\text { submissions }\end{array}$ & $\begin{array}{l}\text { Broadcast assignments } \\
\text { to Initial authors }\end{array}$ & $\begin{array}{l}\text { "Submission_end" } \\
\text { deadline }\end{array}$ \\
\hline 3. & Collecting reviews & $\begin{array}{l}\text { Broadcast artifacts } \\
\text { to Reviewers }\end{array}$ & $\begin{array}{l}\text { "Review_end" } \\
\text { deadline }\end{array}$ \\
\hline 4. & $\begin{array}{l}\text { Analysis of PR } \\
\text { results }\end{array}$ & Gather final Reviews & $\begin{array}{l}\text { "Result_message" } \\
\text { deadline }\end{array}$ \\
\hline 5. & $\begin{array}{l}\text { Session feedback } \\
\text { (additional stage) }\end{array}$ & $\begin{array}{l}\text { Send first feedback } \\
\text { message }\end{array}$ & $\begin{array}{l}\text { End of a course/ } \\
\text { education cycle }\end{array}$ \\
\hline
\end{tabular}

Figure 1 shows PA processes from a Teacher's perspective using a Business Process Model and Notation (BPMN 2.0). It is the most general representation without technological details, i.e. without the lane of PAS.

\subsection{Main use cases}

According to the BPMN diagram (Figure 1), we can populate the list of main PASCA use cases (from a Teacher's perspective, by the mentioned stages of a PA session).

1. Preparation stage:

a. Prepare an assignment (a task description file).

b. Prepare a PR Form with validation rules and assessment criteria (rubrics).

c. Prepare a source list of PA participants (Initial authors) and their e-mail addresses.

d. Fill in the parameters of a PA session and a schedule.

e. Anonymize participants and build a randomization scheme of PR with an initial mapping between Submitters and Reviewers.

2. Submissions collecting stage:

a. Broadcast a task description file (assignment) to the Initial authors.

b. Gather Submissions from the Initial authors.

c. [Optional] Remap Reviewers based on missing Submissions.

3. Reviews collecting stage:

a. Send PR Forms to the Reviewers.

b. Gather Reviews from the Reviewers.

c. Calculate final marks and check status of all PA participants.

4. PR results analysis stage:

a. Send results of the PA session to the Submitters (or all the Initial authors).

b. Gather additional feedback from the Submitters.

c. Build a final report of the PA session.

5. [Optional] Permanently available actions:

a. Check a mailbox availability and working capacity.

b. Archive a mailbox and PA session data.

c. Check status of Submissions and Reviews.

d. Broadcast information letters and feedback.

\subsection{Software requirements}

Based on the weakest links identified during the analysis of PA processes and the review of existing PASs, the desired requirements are formulated. 


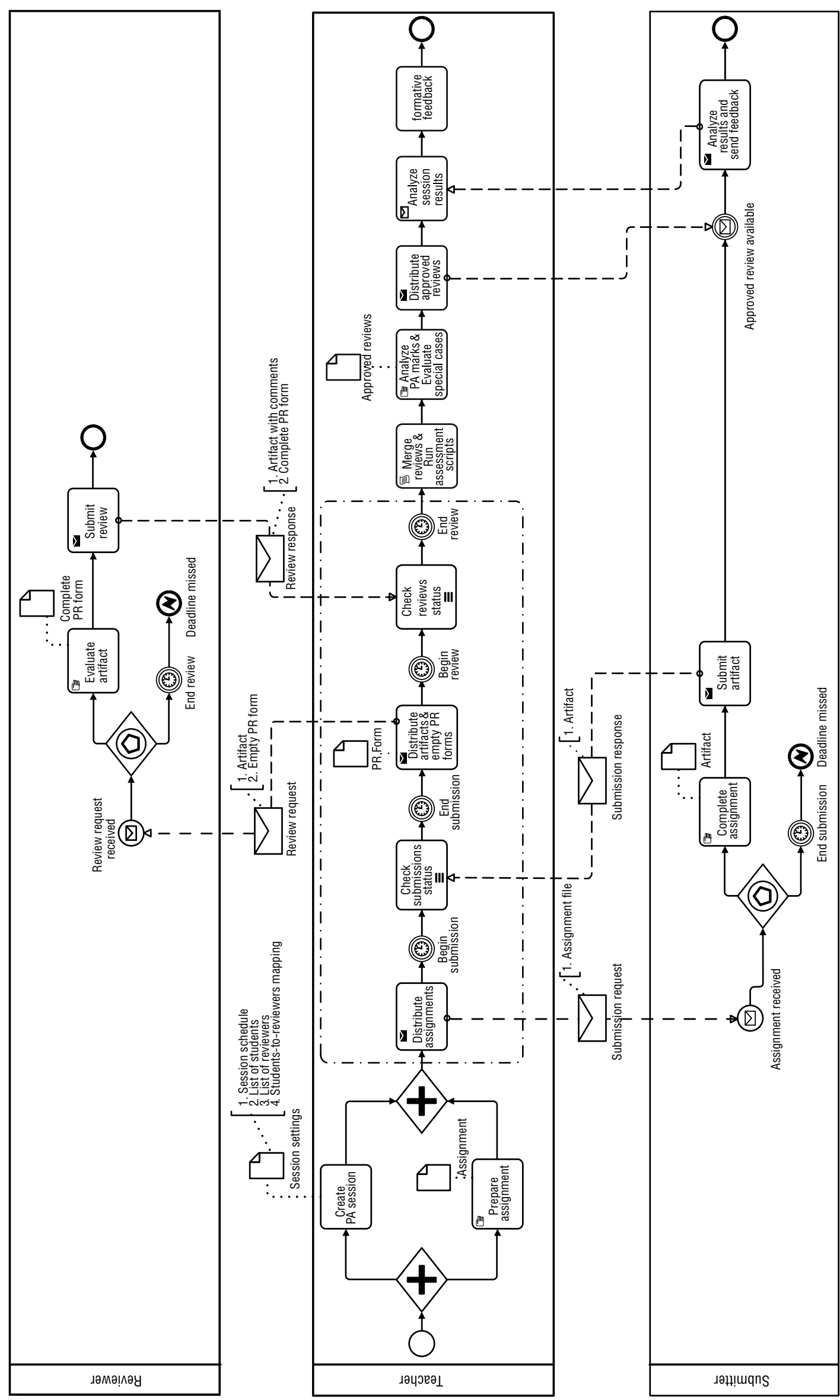

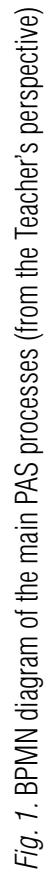


1. PAS should support:

a) complex artifacts as submission content (like source code, design documents, complete software projects, etc.);

b) complex PR forms, which should be easily updated and changed;

c) automatic PR form validation;

d) automatic tentative (coarse) assessment of Artifacts based on Reviews.

2. A Student should not learn to use any additional software (we suppose that now everyone uses e-mail and an office suite).

3. A teacher should be able to tightly integrate PAS into the common IT infrastructure of a university.

Other functional requirements for the use cases listed above:

1. Importing lists of students (Initial authors) with emails from external sources.

2. Automated delivery of a task description (assignment) file converted into PDF format.

3. Support of various e-mail addresses for one student.

4. Basic anonymization of artifacts.

5. Blinding of participants to support a single- and double-blinded review process.

6. Randomization of reviewers.
7. Preparation of PR forms, independent from other PA activities.

8. Automated assessment procedure by PR forms processing after review process.

9. Generating reports about submissions status, reviews status, and final assessment results.

Main non-functional requirements:

1. Use only standard Microsoft Office components.

2. Support any IMAP-compatible mailbox as a "server side".

\section{Software design and functionality}

PASCA was designed to use the Microsoft Office 2010-2016 or Office 365 on a Teacher's computer. Involved components of the Office suite are Excel, Outlook, and Word. The optimal mail server is Microsoft Exchange (2010 or higher), though PASCA supports any IMAP-compatible mailbox. At present, the project has been fully tested in:

1. Microsoft Windows 7, 8.1 and 10 operating systems.

2. Microsoft Office 2013, 2016 and 365.

3. Mailboxes in Google (http://mail.google.com) and Yahoo! (http://mail.yahoo.com) free mail services.

The main metrics of the project are relatively low

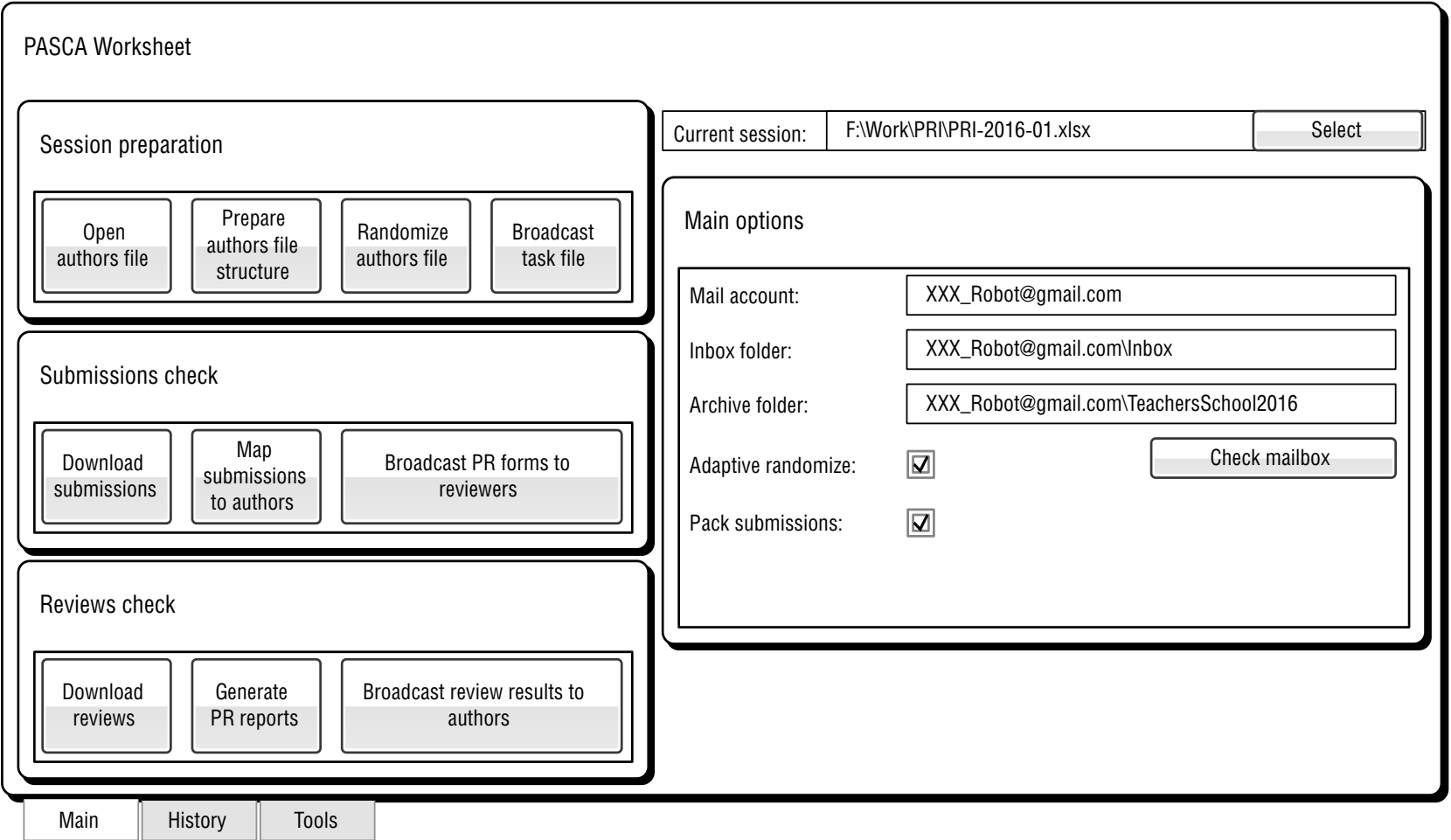

Fig. 2. Layout of a main worksheet in the PASCA workbook 
(about 2400 lines of source code), because the most of low-level tasks are implemented and executed by the components of the Microsoft Office Suite. We use Excel as an application host (Figure 2), a main data storage, and a report builder (the following illustrations in full resolution can be found at https://bitbucket.org/SiberianShaman/pasca/wiki/ScreenShots).

PASCA focuses on main scenarios of a PA process from a Teacher's perspective. The software architecture ensures a high level of PA materials (Authors lists, PR forms, reports) reuse.

\subsection{PA session events and authentication of participants}

A mail-based PAS evidently relies on an e-mail infrastructure [23]. PASCA uses a certain mail-box for communication with participants of a PA session. This mail-box (i.e. e-mail address) may be changed between sessions, but must be constant throughout a session. All the auto-generated messages from this mailbox are signed by the "Peer Review Robot".

MS Outlook is used for all mailbox management tasks. This means that a Teacher needs to set up an Outlook account and specify the address in PASCA settings. This solution may be treated as a drawback, but the result is very handy because of useful additional tools available in Outlook. Options to change a mailbox account and a mailbox folder used for processing e-mail messages are provided.

There are two main types of events in PASCA: facts of an e-mail message send and delivery with timestamps generated by an e-mail system. It is significant that any student may use a secondary e-mail address on a submission stage in addition to a primary e-mail address that is fixed in an Initial authors list. The primary and secondary e-mail addresses of each participant are checked for compliance on the following stages of a PA session. All the data objects at the moment of the event are represented as attachments in the corresponding email messages.

\subsection{PA session workbook}

Each PA session is represented by one excel workbook. The first worksheet of the workbook is a list of Initial authors, the second - PA session parameters ${ }^{2}$, the following - a randomization scheme, a Submissions status, status of Reviews, and various reports. Thus, most of data about a PA session are available in a
PA session workbook and all that data can be analyzed and visualized by standard Excel tools.

We suppose that a Teacher has a list of students and their e-mail addresses. In very rare cases, the Teacher should additionally check the correctness of this list. For example, we faced a problem with letter "ë" of the Russian alphabet, which can be interchanged with "e" in student's name. In the current version of PASCA this case is handled automatically.

\subsection{Anonymization and randomization}

Each Initial author - and, therefore, Submitter and Reviewer - constantly has a random unique 6-digit identifier (ID) from the range [100000-999999] and each PR form has a random unique 7-digit ID from the range [1000000-9999999]. Thus, the ranges of Participants IDs and PR forms IDs do not overlap. After building a PA session workbook from an Initial authors list, all subsequent actions use those IDs.

Several randomization schemes and algorithms were taken into consideration in an attempt to randomize Authors and Reviewers. At first, a basic non-adaptive algorithm is used for standard randomization of all authors2. It is based on the classical Richard Durstenfeld permutation algorithm [24] with checking for nonequal submissions assigned for one Reviewer.

At second, a more interesting adaptive algorithm is used for a uniform workload of the Reviewers, which takes into account missing submissions. We continue experiments on different randomization schemes.

\subsection{Peer review form creation, validation and assessment}

A peer review form (PR form) is the main data object from Reviewer's point of view. A separate Excel file embodies a PR form that supports a multifield review, complex assessment rules, and a validation scheme2. The first row of the first worksheet contains PR form ID, a PA session textual ID (that helps a Reviewer to match PR form and assignment), and a command button that checks the validity of values entered in the form.

The parameters page in a PA session workbook contains a link to the PR form used and the number of fields in the PR form.

\footnotetext{
${ }^{2}$ https://bitbucket.org/SiberianShaman/pasca/wiki/ScreenShots
} 


\section{Pilot adoption and PASCA improvement process}

Relying on the results of Nulty [9] and van Zundert et al. [10], we suppose the applicability of peer-assessment to introductory programming courses was sufficiently approved. So, the adoption of the PASCA prototype was encouraged in the Fall semester of 2015-2016 academic year during an introductory programming course at the Faculty of Computer Science of National Research University Higher School of Economics. Software engineering bachelor students (58 in total) were engaged in three PA sessions. 48 students took part in an anonymous post-course survey. The survey among the others contained questions on students' experience with PASCA. More information about the post-course survey, the results and their discussion may be found in [25].

The authors have shared the PA practice with colleagues and have removed some shortcomings discovered by the early adopters. For now, we are working on the following improvements.

1. Integrating PASCA with a new Microsoft Office 365 technology stack.

2. Rewriting the notification system. If the current version of PASCA uses an external IMAP mailbox, there are no automatic notifications at all due to the unavailability of callback functions on the server side.

3. Helping reviewers with a preliminary artifact verification. PASCA should be able to validate general artifacts or some known types of artifacts, for example, check a file size or compile a source code.

4. Adding adaptive randomization schemes.

5. Increasing blinding quality in small groups of students. This problem is linked to an additional anonymization of artifacts. Thus, we will try to implement a basic check for the presence of personally identifiable information.

6. Adding some analysis and reports for cheating prevention.

\section{Conclusion}

This paper has presented a systematic attempt to optimize business processes of peer assessment in education. We have introduced SRS for a modern PAS and have specified them to a mail-based peer assessment system. Moreover, this paper has introduced the Mail-based Randomized Double-Blinded Peer-assessment System for Complex Artifacts (PASCA), which has been developed according to these requirements. Using this system, participants of educational process (teachers and learners) are not required to master a new business process or to use or set up any additional software except for the standard e-mail system. Furthermore, PASCA supports assessment of artifacts of any type, blinding and randomization during a peer assessment session, complex PR forms with automatic validation and scoring.

Currently, PASCA provides all the functionality declared in this work. Moreover, the system was successfully adopted in the introductory programming course for the first-year software engineering bachelor students. The feedback which was gained during the adoption dictated the directions of the work for the near future. PASCA will be improved by adding additional notifications, data validators, and adaptive randomization algorithms.

Finally, PASCA is claimed to be an open-source project and now it is freely available at the Bitbucket repository (http://bitbucket.org/SiberianShaman/pasca)

\section{References}

1. Clarke S. (2008) Active learning through formative assessment. London: Hodder Education.

2. Tillema H. (2014) Student involvement in assessment of their learning. Designing assessment for quality learning. Dordrecht: Springer.

3. Anson R., Goodman J.A. (2014) A peer assessment system to improve student team experiences. Journal of Education for Business, vol. 89 , no. 1 , pp. $27-34$.

4. Kulrarni C., Wei K.P., Le H., Chia D., Papadopoulos K., Cheng J., Koller D., Klemmer S.R. (2013) Peer and self assessment in massive online classes. ACM Transactions on Computer-Human Interaction (TOCHI), vol. 20, no. 6, pp. 1-31.

5. Hamalainen H., Hyyrynen V., Ikonen J., Porras J. (2011) Applying peer-review for programming assignments. International Journal on Information Technologies \& Security, no. 1, pp. 3-17.

6. Davies P. (2006) Peer assessment: judging the quality of students' work by comments rather than marks. Innovations in Education and Teaching International, no. 43, pp. 69-82.

7. Falchikov N., Goldfinch J. (2000) Student peer assessment in higher education: A meta-analysis comparing peer and teacher marks. Review of Educational Research, vol. 70, no. 3, pp. 287-322.

8. Dochy F., Segers M., Sluijsmans D. (1999) The use of self-, peer and co-assessment in higher education: a review. Studies in Higher Education, vol. 24, no. 3, pp. 331-350.

9. Nulty D.D. (2011) Peer and self-assessment in the first year of university. Assessment \& Evaluation in Higher Education, vol. 36, no. 5, pp. 493-507.

10. van Zundert M., Sluijsmans D., van Merrienboer J. (2010) Effective peer assessment processes: Reasearch findings and future directions. Learning and Instructions, no. 20, pp. 270-279. 
11. Isomottonen V., Tirronen V. (2013) Teaching programming by emphasizing self-direction: How did students react to the active role required of them? ACM Trasactions on Computing Education, vol. 13, no. 2, pp. 6-21.

12. Carroll J.M., Jiang H., Borge M. (2015) Distributed collaborative homework activities in a problem-based usability engineering course. Education and Information Technologies, no. 20, pp. 589-617.

13. Topping K. (1998) Peer assessment between students in colleges and universities. Review of Educational Research, vol. 68, no. 3, pp. $249-276$.

14. Hundhausen C., Agrawal A., Ryan K. (2010) The design of an online environment to support pedagogical code reviews. Proceedings of the 41st ACM Technical Symposium on Computer Science Education, 10-13 March 2010, Milwaukee, Wisconsin, USA, pp. 182-186.

15. Loddington S., Pond K., Wilkinson N., Willmot P. (2009) A case study of the development of WebPA: An online peer-moderated marking tool. British Journal of Educational Technology, no. 40, pp. 329-341.

16. Hyyrynen V., Hamalainen H., Ikonen J., Porras J. (2010) MyPeerReview: An online peer-reviewing system for programming courses. Procceedings of the 10th Koli Calling International Conference on Computing Education Research. 28-31 October 2010, Koli National Park, Finland, pp. 94-99.

17. HEI-UP business process management in higher education institutions. Project results. 2015. Available at: http://www.bpm-hei.eu/index. php/news (accessed 19 August 2015).

18. Lew M.D.N., Awis W.A.M., Schmidt H.G. (2010) Accuracy of students' self-assessment and their beliefs about its utility. Assessment \& Evaluation in Higher Education, vol. 35, no. 2, pp. 135-156.

19. Lin S.S.J., Liu E.Z.F., Yuan S.M. (2001) Web-based peer assessment: feedback for students with various thinking-styles. Journal of Computer Assisted Learning, no. 17, pp. 420-432.

20. Kollar I., Fischer F. (2010) Peer assessment as collaborative learning: A cognitive perspective. Learning and Instruction, no. 20, pp. $344-348$.

21. Freeman M., McKenzie J. (2002) SPARK, a confidential web-based template for self and peer assessment of student teamwork: Benefints of evaluating across different subjects. British Journal of Educational Technology, no. 33, pp. 551-569.

22. Hamer J., Kell C., Spence F. (2007) Peer assessment using Aropä. Proceedings of the Ninth Australasian Conference on Computing Education, vol. 66, pp. 43-54.

23. Klensin J. (2008) RFC-5321: Simple mail transfer protocol. IETF Documents. Available at: https://tools.ietf.org/html/rfc5321 (accessed 01 May 2016).

24. Durstenfeld R. (1964) Algorithm 235: Random permutation. Communications of the ACM, vol. 7, no. 7, p. 420.

25. Maksimenkova O., Neznanov A. (2016) The PASCA: A mail based randomized blinded peer assessment system for complex artifacts. Procedia Computer Science, no. 96, pp. 826-837.

\section{О бизнес-процессах коллаборативного обучения и его компьютерной поддержки: Разработка системы взаимного оценивания}

\section{А.И. Коломиец}

студент факультета компьютерных наук

Национальный исследовательский университет «Высшая школа экономики»

Адрес: 101000, г. Москва, ул. Мясницкая, д. 20

E-mail:aikolomiets@edu.hse.ru

\section{О.В. Максименкова}

старший преподаватель департамента программной инженерии младший научный сотрудник Международной научно-учебной лаборатории интеллектуальных систем и структурного анализа

Национальный исследовательский университет «Высшая школа экономики» Адрес: 101000, г. Москва, ул. Мясницкая, д. 20

E-mail: omaksimenkova@hse.ru

\footnotetext{
${ }^{3}$ Статья подготовлена в ходе проведения исследования в рамках Программы фундаментальных исследований Национального исследовательского университета «Высшая школа экономики» (НИУ ВШЭ) и с использованием средств субсидии в рамках государственной поддержки ведущих университетов Российской Федерации "5-100
} 


\section{А.А. Незнанов}

кандидат технических наук, доцент департамента анализа данных и искусственного интеллекта старший научный сотрудник Международной научно-учебной лаборатории интеллектуальных систем и структурного анализа

Национальный исследовательский университет «Высшая школа экономики»

Адрес: 101000, г. Москва, ул. Мясницкая, д. 20

E-mail: aneznanov@hse.ru

\section{Аннотация}

Взаимное оценивание - важная часть большинства современных учебных технологий. Внимание к этому методу постоянно растет, причем не только как к варианту процедуры оценивания, но и как к процедуре получения информативной обратной связи и технике развития важнейших системных компетенций. Отметим, что большинство практиков отмечают высокую сложность и ресурсоемкость внедрения и использования взаимного оценивания. Бесспорно, что подходящее программное обеспечение, автоматизирующее процессы взаимного оценивания, может существенно упростить внедрение и повысить эффективность этих процессов.

Обзор литературы и существующих программных решений позволяет выявить несколько «узких мест» в функциональности и взаимодействии с пользователем. Во-первых, большинство систем являются независимо развертываемыми web-службами, что расширяет набор инструментов преподавателей и, что более важно, обучаемых. Также это требует отдельных технологических цепочек для поддержки процессов взаимного оценивания и затрудняет интеграцию бизнес-процессов. Во-вторых, авторами не обнаружено доступной бесплатной системы, в которой можно оценивать артефакты, отличные от текстового документа.

В статье рассматриваются требования к современной системе поддержки взаимного оценивания, которая смогла бы широко использоваться преподавателями. После анализа бизнес-процессов взаимного оценивания авторами была разработана оригинальная программная система, получившая название PASCA (peer assessment system for complex artifacts). Продукт использует привычные сервисы электронной почты и не требует изменения никаких других бизнес-процессов образовательной организации. Он обеспечивает стандартные возможности ослепления и рандомизации, а также имеет несколько важных преимуществ: поддержку оценивания произвольных артефактов, создание сложных оценочных листов с автоматической валидацией и простановкой оценок, простой анализ данных сессий взаимного оценивания.

Ключевые слова: оптимизация бизнес-процессов, взаимное оценивание, коллаборативное обучение с компьютерной поддержкой, активное обучение, образовательное программное обеспечение, рандомизация, ослепление.

Цитирование: Kolomiets A.I., Maksimenkova O.V., Neznanov A.A. On business processes of computer-supported collaborative learning: A case of peer assessment system development // Business Informatics. 2016. No. 4 (38). P. $35-46$. DOI: 10.17323/1998-0663.2016.4.35.46.

\section{Литература}

1. Clarke S. Active learning through formative assessment. London: Hodder Education, 2008.

2. Tillema H. Student involvement in assessment of their learning // In: Designing assessment for quality learning. Dordrecht: Springer, 2014.

3. Anson R., Goodman J.A. A peer assessment system to improve student team experiences // Journal of Education for Business. 2014. Vol. 89. No. 1. P. $27-34$

4. Peer and self assessment in massive online classes / C.W.K.P. Kulrarni [et al.] // ACM Transactions on Computer-Human Interaction (TOCHI). 2013. Vol. 20. No. 6. P. 1-31.

5. Hamalainen H., Hyyrynen V., Ikonen J., Porras J. Applying peer-review for programming assignments // International Journal on Information Technologies \& Security, 2011. No. 1. P. 3-17.

6. Davies P. Peer assessment: judging the quality of students' work by comments rather than marks // Innovations in Education and Teaching International. 2006. No. 43. P. 69-82.

7. Falchikov N., Goldfinch J. Student peer assessment in higher education: A meta-analysis comparing peer and teacher marks // Review of Educational Research. 2000. Vol. 70. No. 3. P. 287-322.

8. Dochy F., Segers M., Sluijsmans D. The use of self-, peer and co-assessment in higher education: a review // Studies in Higher Education. 1999. Vol. 24. No. 3. P. 331-350.

9. Nulty D.D. Peer and self-assessment in the first year of university // Assessment \& Evaluation in Higher Education. 2011. Vol. 36. No. 5. P. 493-507.

10. van Zundert M., Sluijsmans D., van Merrienboer J. Effective peer assessment processes: Reasearch findings and future directions // Learning and Instructions. 2010. No. 20. P. 270-279. 
11. Isomottonen $\mathrm{V}$., Tirronen $\mathrm{V}$. Teaching programming by emphasizing self-direction: How did students react to the active role required of them? // ACM Trasactions on Computing Education. 2013. Vol. 13. No. 2. P. 6-21.

12. 12. Carroll J.M., Jiang H., Borge M. Distributed collaborative homework activities in a problem-based usability engineering course // Education and Information Technologies. 2015. No. 20. P. 589-617.

13. Topping K. Peer assessment between students in colleges and universities // Review of Educational Research. 1998. Vol. 68. No. 3. P. 249-276.

14. 14. Hundhausen C., Agrawal A., Ryan K. The design of an online environment to support pedagogical code reviews // Proceedings of the 41st ACM Technical Symposium on Computer Science Education, 10-13 March 2010, Milwaukee, Wisconsin, USA. P. $182-186$.

15. Loddington S., Pond K., Wilkinson N., Willmot P. A case study of the development of WebPA: An online peer-moderated marking tool // British Journal of Educational Technology. 2009. No. 40. P. 329-341.

16. Hyyrynen V., Hamalainen H., Ikonen J., Porras J. MyPeerReview: An online peer-reviewing system for programming courses // Procceedings of the 10th Koli Calling International Conference on Computing Education Research. 28-31 October 2010, Koli National Park, Finland. P. 94-99.

17. HEI-UP business process management in higher education institutions. Project results. 2015. [Электронный pecypc]: http://www. bpm-hei.eu/index.php/news (дата обращения: 19.08.2015).

18. Lew M.D.N., Awis W.A.M., Schmidt H.G. Accuracy of students' self-assessment and their beliefs about its utility // Assessment \& Evaluation in Higher Education. 2010. Vol. 35. No. 2. P. 135-156.

19. Lin S.S.J., Liu E.Z.F., Yuan S.M. Web-based peer assessment: feedback for students with various thinking-styles // Journal of Computer Assisted Learning. 2001. No. 17. P. 420-432.

20. Kollar I., Fischer F. Peer assessment as collaborative learning: A cognitive perspective // Learning and Instruction. 2010. No. 20. P. 344-348.

21. Freeman M., McKenzie J. SPARK, a confidential web-based template for self and peer assessment of student teamwork: Benefints of evaluating across different subjects // British Journal of Educational Technology. 2002. No. 33. P. 551-569.

22. Hamer J., Kell C., Spence F. Peer assessment using Aropä// Proceedings of the Ninth Australasian Conference on Computing Education. 2007. Vol. 66. P. 43-54.

23. Klensin J. RFC-5321: Simple mail transfer protocol // IETF Documents. 2008. [Электронный pecypc]: https://tools.ietf.org/html/ rfc5321 (дата обращения: 01.05.2016).

24. Durstenfeld R. Algorithm 235: Random permutation // Communications of the ACM. 1964. Vol. 7. No. 7. P. 420.

25. Maksimenkova O., Neznanov A. The PASCA: A mail based randomized blinded peer assessment system for complex artifacts // Procedia Computer Science. 2016. No. 96. P. 826-837. 


\title{
Assessment of service quality for complex technical devices based on the Jaynes' information principle
}

\author{
Arkadiy I. Maron \\ Associate Professor, Department of Business Analytics \\ National Research University Higher School of Economics \\ Address: 20, Myasnitskaya Street, Moscow, 101000, Russian Federation \\ E-mail:amaron@hse.ru
}

\begin{abstract}
The Jaynes' information principle (formalism) advanced for the solution of problems of statistical thermodynamics is applied to the solution of a task of assessing the fairness of a contractor who carries out restoration work on a technical system by the method of replacing elements.

The task is the following. The customer possesses a fleet of similar technical devices (for example, cars) certain elements of which are subject to planned replacement. According to the contract, such replacements are carried out by a contractor. Spare elements of three types can be used: new original, new non-original and restored elements. The contract specifies what percentage of spare elements of each type may be used. It is difficult for the customer to check what type of element has been applied. However, for an element of each type it is possible to calculate the average time before the next replacement will be required. The actual average time between requirements for replacement is fixed by the customer.

Based on these data and with the help of Jaynes' information principle, it is possible to find the most objective probabilities of using elements of the various types. Having compared these probabilities with restrictions specified in the contract, the customer draws a conclusion about the fairness of the contractor and, if necessary, takes appropriate action. According to Jaynes' principle, the most objective are probabilities for which entropy according to Shannon reaches a maximum under the set of restrictions. Respectively, the problem of finding their probabilities is simplified to a problem of finding the maximum nonlinear function under the set of restrictions. In this article, the task is formulated mathematically and solved for a case of three variables using the Lagrange method. Calculations for a real situation from the author's practice are given.
\end{abstract}

Key words: maintenance, probability, entropy, Jaynes' principle.

Citation: Maron A.I. (2016) Assessment of service quality for complex technical devices based on the Jaynes' information principle. Business Informatics, no. 4 (38), pp. 47-51. DOI: 10.17323/1998-0663.2016.4.47.51.

\section{Introduction}

$\mathrm{T}$ There are a great many tasks relating to determination of the probabilities of states in which some system is available at present, or was available in the past. However, it is practically impossible to calculate or to determine these probabilities statistically. For example, an organization carries out standard construction projects. Each project consists of certain stages (phases) [1]. At the end of each stage a certain result, for example, the base, walls, etc. is obtained. Delay of a stage's finish leads to delay of the end of the whole project. In the company it is always known how much is the delay of each project, and, as a rule, what are the reasons for such delays. However, these data are insufficient for determining relative probabilities of delays at various stages. This is explained by the fact that the frequency converges with probability rather slowly. Even in the case 
of standard projects, their number is usually not enough for a valid justification [2].

Another example concerns railway transport, where much attention is paid to increasing the reliability and safety of infrastructure facilities directly related with technological process of transportation of goods and passengers. Among infrastructure facilities, an important role belongs to railway automatic devices. Failures of such devices are fixed and investigated, especially if they lead to delays of trains. More attention is paid to dangerous failures, which result, or could lead to crashes [3]. In any case, a service department responsible to the failure is determined. At the same time, there are inevitable discrepancies which significantly influence the reliability of conclusions. That is why it is extremely difficult to find relative probabilities of failures relying on official statistics.

The examples show that the major factors which often make the statistical definition of states of technical and organizational systems impossible are insufficiency and unauthenticity of source data.

\section{Jaynes' principle and its capability}

Definition of the most probable power states is one of the most important problems of statistical thermodynamics. Gibbs received a distribution of probabilities for finding a system in an equilibrium power state $[4,5]$. The distribution received the name "Gibbs distribution" and, according to Feynman, it is "the top of statistical mechanics" [5]. However, Gibbs's approach is extraordinarily difficult. E.T. Jaynes [6] advanced another approach based on maximizing entropy according to Shannon. The relationship between Shannon's entropy and Boltzmann's entropy, which is widely used at the solution of problems of thermodynamics, is presented in $[5,7]$.

Jaynes idea is as follows. Let us consider a system in which the conditions cannot be calculated or measured by an experiment. However, each state of the system has a certain measured implication, the average value of which is known (or can be defined), and the average result of these implications is known from the statistical data. Then the most objective are probabilities of states maximizing Shannon's entropy under restrictions imposed by information about average implications of states.

Let us explain Jaynes' principle on the examples mentioned above. First, let us consider the situation with standard construction projects. Using the network schedule, it is possible to calculate how much delays in each phase will increase the time of the whole project's implementation. The appropriate calculations are usually carried out. Meanwhile, quite often PERT analysis is applied, and sometimes the methods of simulation modeling are used $[8,9]$. Let us allow that the project has $n$ phases and the standard delay of an $i$-th phase leads to the project delay for the period of $T_{i}$. It is established that the average delay of projects in the company is $T$. Let's denote the probability of a delay of $i$-th phase through $p_{i}$. Then it is possible to write an equation showing that the sum of $n$ multiplications $p_{i}$ by $T_{i}$ is equal to $T$. This represents the restriction under which it is necessary to find the distribution of probabilities at which the entropy reaches its maximum.

In a similar way, it is possible to find the distribution of probabilities of failure of railway automatic through the fault of particular service departments. Moreover, the task is reduced to the problem of maximizing Shannon's entropy. The consequences of the failures are the delays of trains measured in hours (such data are always recorded on the railroads). Knowledge of the probabilities of the undesirable states happening in the past allows us to focus resources on reducing the probabilities of states in the future which have the most serious consequences.

\section{Substantial definition of the problem of quality assessment of technical device restoration}

Let us give substantial statement of quality assessment for works of restoring technical devices in the case when restoration is carried out by replacement of elements. The organization has a fleet consisting of a significant number of similar technical devices. Each device consists of a certain number of elements among which there is an element which is worn out during its use. Its wear is indicated by deterioration of a certain parameter of system, the value of which may be measured. On achieving a certain value of this parameter, the worn-out element must be replaced with an operable spare element. Such a maintenance strategy allows us to avoid failure of the device [10]. For performing the replacement works, an organization (hereinafter - the Customer), negotiates a contract with a specialized organization (hereinafter the Contractor). There are three types of spare elements that may be used for replacement: new originals, new non-originals and restored elements. The contract specifies what percentage of spare elements of each type one is allowed to use. It is difficult for the Customer to check all the spare elements used for replacement. However, the Customer records the times between requirements 
for replacement of worn-out elements for each device served by the Contractor. Respectively, the Customer knows the average time between requirements for replacement.

The Customer wishes to know how fairly the Contractor is executing the contract, particularly, whether the Contractor exceeds the limits established for use of nonoriginal and restored elements.

\section{Mathematical definition of the problem of quality assessment of the restoration of technical devices}

The mathematical definition of the problem is as follows. A certain element of a technical device is repeatedly replaced with an operable spare element. Three types of spare elements are used: new originals, new non-originals and restored elements.

When using original spare elements, the average time before the following replacement is $t_{1}$, for non-original spare element the time is $t_{2}$, and for restored spare elements $-t_{3}$. The actual average time between replacements is $T$.

We are required to define the shares of original, nonoriginal and restored spare elements in the total number of replacements. After this, the shares are to be compared with the figures, specified in the contract.

\section{The solution of the task based on Jaynes' principle}

It is required that we determine the probabilities of transition of some faulty element to one of three states: "replaced with an original spare element" (a spare element of the first class), "replaced with a non-original spare element" (a spare element of the second class), "replaced with a restored spare element" (a spare element of the third class). Let us denote these probabilities through $p_{1}, p_{2}$ and $p_{3}$.

Then the average time between replacements (which is known) can be expressed through average times between replacements using spare elements of the first, second and third classes:

$$
T=p_{1} \cdot t_{1}+p_{2} \cdot t_{2}+p_{3} \cdot t_{3} \text {. }
$$

At the same time

$$
p_{1}+p_{2}+p_{3}=1
$$

According to Jaynes' principle, the most objective are those probabilities of states of the element for which, taking into account (1) and (2), Shannon's entropy reaches its maximum:

$H\left(p_{1}, p_{2}, p_{3}\right)=-p_{1} \cdot \ln p_{1}-p_{2} \cdot \ln p_{2}-p_{3} \cdot \ln p_{3} \rightarrow \max$

We will apply the method of Lagrange multipliers to find the maximum of the nonlinear function (3) under restrictions (1) and (2). After appropriate transformations, allowing exclusion of uncertain Lagrange multipliers, we discover that determining the probabilities is reduced to the solution of the system that consists of (1), (2) and the following equation:

$$
p_{1}^{t_{2}-t_{3}} \cdot p_{2}^{t_{3}-t_{1}} \cdot p_{3}^{t_{1}-t_{2}}=1 .
$$

The system of the equations (1), (2) and (4) can be solved by methods included in the Mathcad Prime package. When the required probabilities are found, it becomes possible to compare them with allowable values specified in the contract, and to make a judgement whether the divergence is essential.

\section{Example of calculation}

The results of the study were applied in practice. Let us give an example of calculations with real figures, but without disclosing the names of the organizations that are the Contractor and the Customer.

The Customer possesses a fleet of forty special cars used for construction of the railroads. In each car there is an important element which is subject to mechanical wear in use. The failure model is different from the exponential distribution of a time between failures with fixed intensity. There is an opportunity to reduce the probability of sudden failure of an element, replacing it by an obviously operable spare part. There are two possible strategies of replacement: based on a state and based on working hours of elements. Between them the first option is chosen, because the state of an element may be determined by the deterioration in easily measured car parameter. For replacement works, a contract between the Customer and a specialized repairing organization the Contractor - is negotiated and signed. In the contract, it is specified that the share of non-original spare elements used for replacements should not exceed $15 \%$ of all the replacements. For restored spare parts, such a limit is established at the level of $5 \%$ of all the replacements. The decision allowing use of non-original and restored spare elements is explained by the expensiveness of the original elements. For the Contractor, it is unprofitable to keep too large a volume of original elements, and the Customer does not wish to wait for delivery of such elements under an order. However, the concession is limited: 
the percentage of use of original spare elements should be not less than $80 \%$. If an original spare element is used, the average time before the subsequent replacement is 12 months. For non-original elements, such period is 8 months, and for restored elements -4 months.

In two years of operating the cars, after conclusion of a service contract, it was discovered that the average time between replacements of worn-out elements is 10.25 months. The customer was going to estimate how fairly the Contractor applies the limits of use of non-original and restored spare elements.

The calculations stated above were carried out using Mathcad Prime 3.1 software (the appropriate license was purchased by the Customer).

The following values for probabilities of use of spare elements of the first, second and third types were obtained: $p_{1}=0.66 ; p_{2}=0.25 ; p_{3}=0.09$.

Relying on the calculations, the Customer concluded that the limits were not followed, so a claim was made on the Contractor. The Contractor agreed with it and promised to avoid such deviations in the future.

Let us note the following point. At exact values of the limits, the average time $T_{\mathrm{o}}$ according to (1) should be 11 months. The fact that the actual value was equal to 10.25 months did not allow the Customer to make a convincing complaint. There was a doubt as to whether the deviation was within admissible limits. Calculation of the most likely values of probabilities of use of spare elements of various types allowed us to get an answer to this question.

There is another interesting fact. At the calculated values of probabilities $p_{1}, p_{2}$ and $p_{3}$ the entropy (3) is equal 0.844 nat. For the time of the values stated above, it is the greatest possible value of the entropy under the re- striction (1). The question arises: at what value $T$ does the entropy reach its maximum possible value for a case of three possible states of a replaced element? It is known that for fixed number of possible states of an object, the entropy of a random variable called "number of state" reaches an absolute maximum when probabilities of object states are equal. In our case, the greatest possible value of the entropy $H_{3}=\ln 3=1.1$ nat. It will be reached at $T_{3}$ equal to the average value of times between replacements of spare elements of different types. For the data under consideration $T_{3}$ is 8 months, and then $p_{1}=p_{2}=p_{3}=0.33(3)$.

\section{Conclusion}

For many real organizational and technical systems, there is an actual problem of determining probabilities of their availability in different possible states, while it is impossible to determine the probabilities by classical statistical methods because of the insufficient volume of source data or their low reliability. The Jaynes' information principle of determining the most objective probabilities of states of a complex system relying on their implications often helps to solve such problem. Using Jaynes' principle, the volume of required statistical data decreases dramatically.

In the presented paper, with the help of Jaynes' information principle, the problem of assessing the fairness of a contractor making replacement of wearing-out elements of technical devices is solved. The system of equations for determining the probabilities of using original, non-original and restored spare elements is presented. The practical application of the approach showed the high reliability of the results obtained and their practical usefulness.

\section{References}

1. Tsipes G.L., Tovb A.S. (2009) Proekty i upravlenie proektami v sovremennykh kompaniyakh [Projects and project management in modern companies]. Moscow: Olymp-Business (in Russian).

2. Boss V. (2015) Lektsii po matematike. Veroyatnost. Informatsiya. Statistika [Lectures on mathematics. Probability. Information. Statistics]. Moscow: LENAND (in Russian).

3. Lisenkov V.M. (1999) Statisticheskaya teoriya bezopasnosti dvizheniya poezdov [Statistical theory of trains traffic safety]. Moscow: VINITI RAN (in Russian).

4. Lavenda B. (1999) Statisticheskaya fizika. Veroyatnostnyiy podhod [Statistical physics. Probabilistic approach]. Moscow: Mir (in Russian).

5. Maron V.I. (2011) Statisticheskie modeli na osnove informatsionnogo podhoda Dzheynsa [Statistical models based on Jaynes' information principle]. Moscow: Max Press (in Russian).

6. Jaynes E.T. (2003) Probability theory: The logic of science. Cambridge: Cambridge University Press.

7. Chernavskiy D.S. (2001) Sinergetika i informatsiya. Dinamicheskaya teoriya informatsii [Synergetrics and information. Dynamic theory of information]. Moscow: Nauka (in Russian).

8. Akopov A.S. (2014) Imitatsionnoe modelirovanie [Simulation modeling]. Moscow: Urait (in Russian).

9. Isaev D.V. (2014) Modelirovanie realizatsii proektov vnedreniya analiticheskikh informatsionnykh sistem [Modeling of analytical information systems implementation projects]. Audit and Financial Analysis, no. 6, pp. 416-422 (in Russian).

10. Breydo A.I., Ovsyanikov V.A. (1983) Organizatsiya obsluzhivaniya zheleznodorozhnyih ustroystv avtomatiki i svyazi [Organization of service of railway devices of automatic equipment and communication]. Moscow: Transport (in Russian). 


\title{
Оценка качества обслуживания сложных технических устройств на основе информационного принципа Джейнса
}

\author{
А.И. Марон \\ кандидат технических наук, доцент кафедры бизнес-аналитики \\ Национальный исследовательский университет «Высшая школа экономики» \\ Адрес: 101000, г. Москва, ул. Мясницкая, д. 20 \\ E-mail:amaron@hse.ru
}

\begin{abstract}
Аннотация
Информационный принцип (формализм) Джейнса, предложенный для решения задач статистической термодинамики, применен для решения задачи об оценке добросовестности исполнителя, осуществляющего восстановление технической системы методом замены элементов.

Постановка задачи выглядит следующим образом. Заказчик обладает значительным парком однотипных технических устройств (например, автомобилей), определенные элементы которых подлежат плановой замене. По договору замену в плановом порядке осуществляет исполнитель. Для замены могут использоваться запасные элементы трех типов: новые оригинальные, новые неоригинальные и восстановленные. В договоре указано, какой процент запасных элементов каждого типа можно использовать. Заказчику затруднительно каждый раз проверять, какой именно элемент установлен. Однако для элемента каждого типа можно рассчитать среднее время до наступления момента, когда потребуется очередная замена. Фактическое среднее время между требованиями о замене фиксируется заказчиком.

На основе этих данных с помощью информационного принципа Джейнса можно найти наиболее объективные вероятности использования исполнителем элементов различных типов. Сравнив эти вероятности с лимитами, указанными в договоре, заказчик делает вывод о добросовестности исполнителя и, в случае необходимости, принимает необходимые меры. В соответствии с принципом Джейнса, наиболее объективными являются вероятности, при которых энтропия по Шеннону достигает максимума при заданных ограничениях. Соответственно, задача их нахождения сводится к задаче нахождения экстремума нелинейной функции при заданных ограничениях. В работе эта задача сформулирована математически и решена для случая трех переменных с помощью метода множителей Лагранжа. Приведен расчет для реальной ситуации из практики автора.
\end{abstract}

Ключевые слова: техническое обслуживание, вероятность, энтропия, принцип Джейнса.

Цитирование: Maron A.I. Assessment of service quality for complex technical devices based on the Jaynes' information principle // Business Informatics. 2016. No. 4 (38). P. 47-51. DOI: 10.17323/1998-0663.2016.4.47.51.

\section{Литература}

1. Ципес Г.Л., Товб А.С. Проекты и управление проектами в современных компаниях. М.: Олимп-Бизнес, 2009. 480 с.

2. Босс В. Лекции по математике. Вероятность. Информация. Статистика. М.: ЛЕНАНД, 2015. 224 с.

3. Лисенков В.М. Статистическая теория безопасности движения поездов. М: ВИНИТИ РАН, 1999. 332 с.

4. Лавенда Б. Статистическая физика. Вероятностный подход / Пер. с англ. М.: Мир, 1999. 432 с.

5. Марон В.И. Статистические модели на основе информационного подхода Джейнса. М.: Макс Пресс, 2011. 156 с.

6. Jaynes E.T. Probability theory: The logic of science. Cambridge: Cambridge University Press, 2003. 727 p.

7. Чернавский Д.С. Синергетика и информация. Динамическая теория информации. М.: Либроком, 2016. 302 с.

8. Акопов А.С. Имитационное моделирование. М.: Юрайт, 2014. 389 с

9. Исаев Д.В. Моделирование реализации проектов внедрения аналитических информационных систем // Аудит и финансовый анализ. 2014. № 6. С. 416-422.

10. Брейдо А.И., Овсяников В.А. Организация обслуживания железнодорожных устройств автоматики и связи. М.: Транспорт, 1983. $208 \mathrm{c}$. 


\title{
Adaptive modification of the particle swarm method based on dynamic correction of the trajectory of movement of individuals in the population
}

\author{
Yu.V. Minaeva \\ Senior Lecturer, Department of Computer Aided Design Systems and Information Systems \\ Voronezh State Technical University \\ Address: 14, Moscow Avenue, Voronezh, 394026, Russian Federation \\ E-mail:julia_min@mail.ru
}

\begin{abstract}
Evolutionary search methods are successfully used for deferent modeling and optimization tasks due to their universality and the relative simplicity of realization in practice. However, a significant problem of using them is related with premature convergence of the computational algorithm due to incomplete exploration of the search space. This happens when all particles come into space of the first found, perhaps local optimum and cannot get out of it. To solve the problem, it is necessary to develop control procedures correcting movements of the individuals in the population.

This paper proposes a particle swarm optimization adaptive modification, permitting dynamic changes to the particles' trajectory to find more promising locations. The method is based on the opportunity to change the displacement vector individually for each particle depending on previous iteration effectiveness. For this purpose, procedures of direction choice and dynamic change of particle movement free parameters are added in the proposed modification. As opposed to the canonic swarm algorithm version, where all individuals converge on one particle with the best value found, in the new modification each particle chooses its displacement direction independently and can change it if the direction will be identified as ineffective. This approach makes it possible to reduce the probability of premature convergence of the algorithm and to explore given search space better, all of which is especially important for the multimodal function with complex landscape. The proposed method was tested on the standard set of test functions for continuous optimization, and it showed high reliability with relatively small use of time and computer resources.
\end{abstract}

Key words: optimization, evolutionary algorithms, particle swarm optimization, premature convergence, adaptation of the algorithm, hybrid algorithm.

Citation: Minaeva Yu.V. (2016) Adaptive modification of the particle swarm method based on dynamic correction of the trajectory of movement of individuals in the population. Business Informatics, no. 4 (38), pp. 52-59.

DOI: $10.17323 / 1998-0663.2016 .4 .52 .59$.

\section{Introduction}

I $\mathrm{n}$ the process of design studies of complex technical and economic systems, we often see a task of an optimal choice of those internal characteristics of the system that describe its structure or behavior. These tasks include formation of the production program of the enterprise, the choice of equipment and production technology, justification of layout diagrams, selection and assessment of risks of investment projects, and so on. To increase the effectiveness and speed of 
implementation of procedures of optimal search, one develops a great number of methods, but almost all of them have restrictions related to the nature of the mathematical model of the system under study. From this perspective, the most universal are controlled search algorithms based on the processes of evolutionary development of biological populations. One of such method is the particle swarm optimization (PSO), which uses the model of behavior of complex self-organizing systems with social structure. Such systems consist of simple interacting agents, each of which behaves independently of the others, but as a consequence the behavior of the entire multiagent system turns out to be intelligent [1].

Potential solutions in the PSO are represented as a population of living organisms, each of which occupies a certain position inside the swarm. The reason for the existence of all organisms of the population consists in increasing of the degree of individual utility due to displacement within the location with the best values of the objective function. To achieve this purpose, the particles are constantly updating their coordinates, using both their own knowledge and the experience gained by the rest of organisms of the population [2].

Up to this moment, a great number of modifications of the canonical PSO has been developed, but many of them retain the disadvantages inherent in the original algorithm. One of the most promising directions of research in the field of evolutionary algorithms is the study of adaptive properties of the PSO, improvement of which will increase the efficiency and universality of the search procedures.

The purpose of this scientific paper consists in developing an adaptive modification of the PSO making it possible to carry out dynamic correction of the trajectory of particle movement for the purpose of more effective investigation of the targeted field of search. The proposed method is based on the possibility each particle has to choose the direction, the movement in which increases its usefulness to the population.

\section{Classical particle swarm optimization}

Let us suppose that our swarm consists of $n$ particles. Each of the swarm particles at any moment can be described by its coordinates $x_{i}=\left\{x_{i 1}, x_{i 2}, \ldots, x_{i d}\right\}$ and velocity $v_{i}=\left\{v_{i 1}, v_{i 2}, \ldots, v_{i d}\right\}$, while $i$ - number of particle $(i=1, \ldots, n)$, and $d-$ the search space dimension. In this case, the whole swarm of particles at the $k$-th instant of time is characterized by the vector of coordinates $x_{k}=\left\{x_{1}, x_{2}, \ldots, x_{n}\right\}$ and vector of velocities of all the particles $v_{k}=\left\{v_{1}, v_{2}, \ldots, v_{n}\right\}$. In accordance with the canonical particle swarm optimization developed by Kennedy and Eberhart [1], iterations are performed in accordance with the following pattern:

$$
\begin{gathered}
v_{k+1}=\alpha v_{k}+\beta r_{1}\left(p_{k}-x_{k}\right)+\gamma r_{2}\left(g_{k}-x_{k}\right), \\
x_{k+1}=x_{k}+v_{k+1} .
\end{gathered}
$$

Moreover, $p_{k}$ and $g_{k}$ are the coordinates of the best solution found by the particle itself and by all the swarm, respectively, $\alpha, \beta, \gamma$ are free parameters of the algorithm, and $r_{1}$ and $r_{2}$ are random numbers within the range $[0,1]$. Coefficients $\alpha, \beta$ and $\gamma$ determine the degree of influence of each of the three components on the particle velocity. Value $\alpha$ is responsible for the persistence of the particle movement. If value $\alpha$ is close to 1 , then the particle continues its path, thus exploring all the search space. Otherwise, the particle tends to the best value (its own or the social one), and will be staying in the area around it. Value $\beta$ reflects the influence of cognitive component, that is determination of the particle to go back to the "best" value, in terms of the objective function, found by it earlier. Value $\gamma$ expresses the social component of velocity, that is the tendency of the particle displacement to the current best solution found by the remaining particles [2].

The disadvantages of the canonical method are as follows [2]:

$\downarrow$ the possibility of the particle coordinates leaving the function tolerance range limits;

$\downarrow$ premature convergence of the algorithm to the first extreme (generally local one) and impossibility of any further search.

\section{Modifications of particle swarm optimization}

To remedy the shortcomings of the method, a great number of modifications have been developed, some of which are aimed at improving the work of the entire algorithm as a whole, while the others are designed to solve problems of a particular class.

All the modifications developed can be assigned to one of the following groups:

$\diamond$ modification of the cognitive component;

$\diamond$ modification of the social component;

$\diamond$ selection of free parameters of the algorithm;

$\diamond$ hybridization of algorithms. 
The most significant modifications of the cognitive component of the canonical algorithm comprise consideration in the velocity formula of not only the "positive" experience of the particle, but also the negative experience, that is, the desire to move away from the "bad" values of the objective function [3], as well as the possibility of forced displacement of the particle during prolonged stagnation of its coordinates [4].

Modifications of the social component suppose consideration of influence of not only the best solution at the given moment, but also the current values of the remaining particles. To this group can be assigned such algorithms as the fully informed PSO, in which the greatest influence on the particle movement is exerted by the particles with "good" values [5], and the PSO based on the ratio of "value-distance", where the degree of influence of each particle depends on the proximity of its location [2].

Influence of the social component upon the effectiveness of the optimal search procedures is largely determined by the topological structure of the population, because the size of the sub-aggregate of particles with which each individual particle can share its experiences depends on precisely this characteristic [2]. Research studies on the effectiveness and convergence of the PSO and its modifications under various topological structures show that the topologies of weak cohesion of the particles, that is those with a few number of neighbors, allow more effective research of the search space, and reduce the likelihood of premature convergence of the algorithm $[2,5,6]$.

The effectiveness and reliability of the PSO is largely dependent on observance of the correct balance between the stages of the search space research and location of the extremum. To regulate the interrelationships between these stages, one uses such free parameters of the algorithm as $\alpha, \beta$ and $\gamma$, for which various scientific studies suggest the use of both constant values and time-dependent ones. For example, for coefficient $\alpha$ there are developed the following patterns of increments of the coefficient values $[7,8]$ :

$\diamond$ linear:

$$
\alpha_{k}=\alpha_{\max }-\frac{\left(\alpha_{\max }-\alpha_{\min }\right)}{T_{\max }} k,
$$

where $\alpha_{\max }$ and $\alpha_{\min }-$ permissible maximum and minimum values of the coefficient;

$T_{\max }$ - the maximum possible number of iterations; $\diamond$ non-linear:

$$
\alpha_{k}=\alpha_{\min }+\frac{\left(\alpha_{\max }-\alpha_{\min }\right)}{T_{\max }^{2}}\left(T_{\max }-k\right)^{2} .
$$

$\checkmark$ exponential:

$$
\alpha_{k}=\alpha_{\text {min }}+\left(1-\alpha_{\text {min }}\right) e^{-\lambda k},
$$

where $\lambda$ is a defined constant.

When using the linear and nonlinear patterns, pre-assignment of $T_{\max }$ is mandatory.

For coefficients $\beta$ and $\gamma$ it is also recommended to use both constant values $[1,2,9]$ and time-dependent ones $[9,10]$.

Such binding of changes of the coefficients to the time of the algorithm execution can lead to insufficiently effective search for solutions, because it is impossible to precisely predict at which exact iteration the optimum will be detected and localized. To remedy this shortcoming, scientific papers $[8,9]$ propose adaptive modifications of the particle swarm optimization, making possible more objective control over the optimization process.

Scientific paper [9] proposes to divide the solutionachieving process into four stages, depending on the range of particles straggling: research investigation of the search area, optimum localization, stagnation, and leaving the state of stagnation. Each stage is characterized by a certain strategy for changing the coefficients. At the stage of research investigation of the search area, the coefficient $\beta$ increases, and $\gamma$ decreases; during the optimum localization $\beta$ and $\gamma$ are changing insignificantly; in case of stagnation, the coefficients are slightly increasing; and while leaving the state of stagnation $\beta$ decreases, and $\gamma$ increases. The authors suggest changing the persistence coefficient depending on the rate of change in the value of the objective function.

The particle swarm optimization, as well as other evolutionary algorithms, can be easily used as a part of hybrid-type circuits. For example, for determination of the new particle velocity, scientific papers [11-13] propose to use selection, cross-breeding and mutation operations taken from the genetic algorithm. Apart from that, to improve the quality of this method on can use local search and differential evolution [14]. Particle swarm optimization can be also used in combination with non-evolutionary algorithms or their component parts (for example, scientific paper [14] shows the use of operations of stretching, reflection and displacement from the Nelder-Mead method of deformed polygon [15]). Multi-swarm algorithms [16], consisting of 
several swarms, each of which, in the general case, possesses its own set of parameters, also represent a special case of hybridization.

\section{Particle swarm optimization with adaptation of the movement trajectory}

Canonical particle swarm optimization assumes the rushing of all the particles to one center having currently the best value of the objective function. However, this process can lead, in the first place, to premature stagnation of the algorithm, and, in the second place, to departure of the particles from the advantageous locations and loss of values of functions therein.

To remedy the mentioned shortcomings, it is suggested to carry out a dynamic correction of the trajectory of movement of each particle by means of adaptive selection of direction and changes in the degree of influence of both its own and social experiences. For this purpose, the following procedures are added to the classic version of this method:

$\downarrow$ procedure of selection by each particle $x_{i}$ of its own "social leader" $x_{j}, j=1, \ldots, n$, with the help of tournament selection method borrowed from the genetic algorithm;

$\downarrow$ procedure of correction of values of coefficients $\alpha$, $\beta, \gamma$.

The algorithm for the dynamic adaptation of the particle swarm optimization includes the following steps:

1. Initialization of values of velocity, coordinates of the particles and the free coefficients

$$
\begin{gathered}
v_{i}^{0}=\operatorname{rnd}\left(D_{v}\right), x_{i}^{0}=\operatorname{rnd}\left(D_{x}\right), \\
p_{i}^{o}=x_{i}^{0}, y_{i}=i, \\
\alpha_{i}^{1}=\alpha_{-} \text {max }, \beta_{i}^{1}=\beta_{-} \max , \gamma_{i}^{1}=\gamma_{-} \min ,
\end{gathered}
$$

where $D_{v}, D_{x}-$ tolerance ranges of the velocities and coordinates of the particles;

$y-$ an array containing numbers of those particles, towards which the social component of the particle velocity vector is directed.

There shall be preset the number of iteration $k=1$.

2. Calculation of values of the objective function $f\left(x_{i}^{k-1}\right)$ and updating of the list of the best values found for all particles

$$
p_{i}^{k}=\left\{\begin{array}{l}
x_{i}^{k-1}-\text { when } f\left(x_{i}^{k-1}\right)<f\left(p_{i}^{k-1}\right) . \\
\text { otherwise, } p_{i}^{k-1}
\end{array}\right.
$$

3 . In the event $k<2$, then transfer to sub-paragraph 4 ; otherwise one performs the procedure of dynamic adaptation of parameters of the particle movement, including the following two stages:

a) Selection of the direction of movement of the particle depending on changes in its usefulness by means of the selection tournament method:

$$
y_{i}=\left\{\begin{array}{l}
\arg \min \left(f\left(\tilde{X}_{i}\right)\right)-\text { when } f\left(x_{i}^{k}\right)>f\left(x_{i}^{k-1}\right)+\delta f, \\
y_{i},- \text { otherwise }
\end{array}\right.
$$

where $\tilde{X}_{i}-$ a random sub-aggregate of particles to be selected for particle $x_{i}, \tilde{X}_{i} \subseteq X$;

b) Correction of those coefficient that are responsible for the movement persistence and the degree of influence of the cognitive and social components of velocity:

$$
\begin{aligned}
& \alpha_{i}^{k+1}=\alpha_{i}^{k}-\delta \varkappa, \\
& \beta_{i}^{k+1}=\beta_{i}^{k}-\delta \varkappa, \\
& \gamma_{i}^{k+1}=\gamma_{i}^{k}+\delta \varkappa,
\end{aligned}
$$

where $\delta \varkappa-$ a correction to the values of coefficients $\alpha, \beta$, $\gamma$, to be defined as follows:

$$
\delta \varkappa=\frac{f\left(x_{i}^{k-1}\right)-f\left(x_{i}^{k}\right)}{f\left(x_{i}^{k-1}\right)},
$$

To ensure that the algorithm works correctly, after recalculation of the coefficients one should carry out verification of the new values belonging to the permissible intervals:

$$
z_{j}=\left\{\begin{array}{l}
z_{-} \min _{j}, \text { when } z_{j}<z_{-} \min _{j}, \\
z_{j}, \quad \text { when } z_{-} \min _{j} \leq z_{j} \leq z_{-} \max _{j}, \\
z_{-} \max _{j}, \text { when } z_{j}>z_{-} \max _{j},
\end{array}\right.
$$

where $z=\left\{\beta_{i}^{k}, \gamma_{i}^{k}, \alpha_{i}^{k}\right\}-$ an array of current values of the coefficients;

$z_{-} \min =\left\{\alpha_{-} \min , \beta_{-} \min , \gamma_{-} \min \right\}$,

$z_{-} \max =\left\{\alpha \_\max , \beta_{-} \max , \gamma_{-} \max \right\}-$ arrays with predetermined minimum and maximum values for each coefficient, $j=1, \ldots, 3$.

4. Recalculation of velocity and coordinates of the particles:

$$
\begin{gathered}
v_{i}^{k}=\alpha_{i}^{k} v_{i}^{k-1}+\beta_{i}^{k} r_{1}\left(p_{i}^{k-1}-x_{i}^{k-1}\right)+\gamma_{i}^{k} r_{2}\left(x_{y_{i}}^{k-1}-x_{i}^{k-1}\right), \\
x_{i}^{k}=x_{i}^{k-1}+v_{i}^{k}
\end{gathered}
$$

5. If the condition of halting algorithm $\left|f\left(x_{i}^{k}\right)-f\left(x_{i}^{k-1}\right)\right| \leq \varepsilon$, is satisfied and $\varepsilon$ - permissible error of calculations, then we see the end of work of the algorithm, otherwise there should be set the number of iteration number $k=k+1$ and transfer to sub-paragraph 2. 
Table 1.

A set of test functions to check the algorithm

\begin{tabular}{c|c|c}
\hline Name & Formula & Interval \\
\hline Spherical function & $F_{1}(x)=\sum_{i=1}^{n} x_{i}^{2}$ & $x \in(-5,5)$ \\
\hline Rosenbrock's function & $F_{2}(x)=\sum_{i=1}^{n-1}\left(100\left(x_{i+1}-x_{i}^{2}\right)^{2}+\left(x_{i}-1\right)\right)$ & $x \in(-2.5,2.5)$ \\
\hline De Jong's function 2 & $F_{3}(x)=\frac{-100}{100 \cdot\left(x_{1}^{2}-x_{2}\right)+\left(1-x_{1}\right)^{2}+1}$ & $x \in(-5,5)$ \\
\hline Rastrigin's function & $F_{4}(x)=10 n+\sum_{i=1}^{n}\left(x_{i}^{2}-10 \cos \left(2 \pi x_{i}\right)\right)$ & $x \in(-5,5)$ \\
\hline
\end{tabular}

To assess the effectiveness of the proposed algorithm, let us compare its work with the canonical PSO, the fully informed particle swarm (FIPS) [5], and the adaptive PSO (APSO), proposed in [9]. Let us denominate the developed modification with the dynamic correction of the trajectory of the particle movement as TPSO. Experimental research study of the methods was carried out at the following parameters:

for all the methods, there is set the size of population of 30 particles and a time restriction of 2000 iterations;

$\diamond$ for PSO, coefficient $\alpha$ decreases in a linear pattern from $\alpha_{\text {max }}=0.9$ to $\alpha_{\text {min }}=0.4$, at coefficients $\beta=\gamma=$ 1.49618 [2];

$\diamond$ for FIPS $\alpha=0.7298, \beta=\gamma=2.05[5]$;

$\diamond$ for methods APSO and TPSO there are set boundaries $\alpha_{\text {max }}=0.9, \alpha_{\text {min }}=0.4, \beta_{\text {max }}=2.5, \beta_{\text {min }}=1.5, \gamma_{\max }=2.5$, $\gamma_{\min }=1.5$ [9].

The test functions used (Table 1) were taken from the recommended standard set of test tasks of continuous optimization [2], and they allow us to check the quality of searching the extrema for functions with a different topography of the search space. Two test functions (Rosenbrock and spherical) are unimodal, and the rest are complex multimodal ones. For all the functions, the dimension of the coordinate space $n=10$.

To compare various versions of the PSO, one uses such criteria as the efficiency of search procedures, number of iterations spent on the search for an optimum, and solution achieving time. As a solution time, one takes the difference between the system time of the computer measured before the start of the calculations and after their completion. Table 2 shows the average values of the given criteria. The best value in each line is highlighted in semi-bold.

Based on the results of the computing experiment, it can be concluded that the proposed algorithm has demonstrated on the set of test functions used high effectiveness for both unimodal and complex multimodal tasks. Moreover, to search for an extremum it took fewer iterations and consumed less time for the processor operation than the rest of the PSO modifications (on three of the four test functions). In accordance with its parameters, the proposed method is close to the APSO, however its advantage consists in a simpler practical implementation and less time required to search for solutions.

\section{Conclusion}

This scientific paper proposes a hybrid modification of PSO that makes it possible to carry out adaptive correction of the particle movement trajectory depending on the effectiveness of performance of the optimal search procedure at the previous iteration. Such a pattern of achieving a solution allows particles to move quickly into the most advantageous locations due to the dynamic changes in the degree of influence of the cognitive and social components of their velocity. The modification of the canonical method considered was tested on standard test tasks of continuous optimization. Based on the test results, it can be concluded that the implementation of dynamic correction of the particles' movement trajectory allows us to increase the effectiveness of the global optimum search process and to reduce the evolution time as compared with the existing modifications of the PSO. 
Criteria of effectiveness of various versions of the PSO

Table 2.

\begin{tabular}{|c|c|c|c|c|c|}
\hline \multirow{2}{*}{ Function } & \multirow{2}{*}{ Griteria } & \multicolumn{4}{|c|}{ Methods of solution } \\
\hline & & PSO & FIPS & APSO & TPSO \\
\hline \multirow{3}{*}{$F_{1}(x)$} & Effectiveness & $100 \%$ & $100 \%$ & $100 \%$ & $100 \%$ \\
\hline & Number of iterations & 523.4 & 492.1 & 478.5 & 475.4 \\
\hline & Solution time & 0.311 & 0.302 & 0.324 & 0.305 \\
\hline \multirow{3}{*}{$F_{2}(x)$} & Effectiveness & $100 \%$ & $100 \%$ & $100 \%$ & $100 \%$ \\
\hline & Number of iterations & 591.2 & 524.7 & 489.1 & 498.3 \\
\hline & Solution time & 0.408 & 0.397 & 0.415 & 0.380 \\
\hline \multirow{3}{*}{$F_{3}(x)$} & Effectiveness & $90.1 \%$ & $96.5 \%$ & $100 \%$ & $100 \%$ \\
\hline & Number of iterations & 754.5 & 685.4 & 621.2 & 613.8 \\
\hline & Solution time & 0.634 & 0.605 & 0.615 & 0.594 \\
\hline \multirow{3}{*}{$F_{4}(x)$} & Effectiveness & $92.5 \%$ & $97.1 \%$ & $100 \%$ & $100 \%$ \\
\hline & Number of iterations & 712.9 & 647.5 & 597.2 & 584.1 \\
\hline & Solution time & 0.612 & 0.594 & 0.618 & 0.590 \\
\hline \multirow{3}{*}{ Average value } & Effectiveness & $95.7 \%$ & $98.4 \%$ & $100 \%$ & $100 \%$ \\
\hline & Number of iterations & 645.4 & 587.4 & 546.5 & 542.9 \\
\hline & Solution time & 0.491 & 0.474 & 0.493 & 0.467 \\
\hline
\end{tabular}

\section{References}

1. Kennedy J., Eberhart R.C. (1995) Particle swarm optimization. Proceedings of the IEEE International Conference on Neural Networks (ICNN‘95), 27 November - 01 December 1995, Perth, Australia, vol. 4, pp. 1942-1948.

2. Karpenko A.P., Seliverstov A.P. (2010) Globalnaya bezuslovnaya optimizacia roem chastits na graficheskih processorah arhitektury CUDA [Global unconstrained particle swarm optimization on graphic processors with CUDA architecture]. Science and Education: Electronic Scientific and Technical Edition, no. 4. Available at: http://technomag.edu.ru/doc/142202.html (accessed 01 July 2016) (in Russian).

3. Yang C., Simon D. (2005) A new particle swarm optimization technique. Proceedings of the 18th International Conference on Systems Engineering (ICSEng'05), 16-18 August 2005, Las Vegas, USA, pp. 164-169.

4. Xie X., Zhang W., Yang Z. (2002) Adaptive particle swarm optimization on individual level. Proceedings of the 6th International Conference on Signal Processing (ICSP'02), 26-30 August 2002, Beijing, China, pp. 1215-1218.

5. Mendes R., Kennedy J., Neves J. (2004) The fully informed particle swarm: Simpler, maybe better. IEEE Transactions on Evolutionary Computation, vol. 8, no. 3, pp. 204-210.

6. Kennedy J., Mendes R. (2002) Population structure and particle swarm performance. Proceedings of the 2002 Congress on Evolutionary Computation (CEC'02), 12-17 May 2002, Washington, USA, pp. 1671-1676.

7. Parsopoulos K.E., Vrahatis M.N., Eds. (2010) Particle swarm optimization and intelligence: Advances and applications. N.Y.: IGI Global.

8. Clerc M. Particle swarm optimization. London: ISTE, 2006.

9. Zhan Z., Zhang J., Li Y., Chung H.S.H. (2009) Adaptive particle swarm optimization. IEEE Transactions on Systems, Man, and Cybernetics. Part B, vol. 39, no. 6, pp. 1362-1381.

10. 10. Ratnaweera A., Halgamuge S.K., Watson H.C. (2004) Self-organizing hierarchical particle swarm optimizer with time-varying acceleration coefficients. IEEE Transactions on Evolutionary Computation, vol. 8, no. 3, pp. 240-255.

11. Angeline P.J. (1998) Using selection to improve particle swarm optimization. Proceedings of the 1998 IEEE International Conference on Evolutionary Computation (ICEC'98). 4-9 May 1998, Anchorage, Alaska, USA, pp. 84-89.

12. Chen Y.P., Peng W.C., Jian M.C. (2007) Particle swarm optimization with recombination and dynamic linkage discovery. IEEE Transactions on Systems, Man, and Cybernetics. Part B, vol. 37, no. 6, pp. 1460-1470. 
13. Andrews P.S. (2006) An investigation into mutation operators for particle swarm optimization. Proceedings of the 2006 IEEE Congress on Evolutionary Computation, 16-21 July 2006, Vancouver, BC, Canada, pp. 1044-1051.

14. Liang J.J., Suganthan P.N. (2005) Dynamic multi-swarm particle swarm optimizer with local search. Proceedings of the 2005 IEEE Congress on Evolutionary Computation (CEC'05), 2-5 September 2005, Edinburgh, Scotland, pp. 522-528.

15. Gimmler J., Stützle T., Exner T.E. (2006) Hybrid particle swarm optimization: An examination of the influence of iterative improvement algorithms on performance. Proceedings of the 5th International Workshop "Ant Colony Optimization and Swarm Intelligence" (ANTS 2006), 4-7 September 2006, Brussels, Belgium, pp. 436-443.

16. Jordan J., Helwig S., Wanka R. (2008) Social interaction in particle swarm optimization, the ranked FIPS, and adaptive multi-swarms. Proceedings of the 10th Annual Conference on Genetic and Evolutionary Computation (GECCO'08), 12-16 July 2008, Atlanta, USA, pp. 49-56.

\title{
Адаптивная модификация метода роя частиц на основе динамической коррекции траектории движения особей в популяции
}

\section{Ю.В. Минаева}

старший преподаватель кафедры систем автоматизированного проектирования и информационных систем Воронежский государственный технический университет

Адрес: 394026, г. Воронеж, Московский пр-т, д. 14

E-mail:julia_min@mail.ru

\begin{abstract}
Аннотация
Методы эволюционного поиска успешно применяются для решения разнообразных задач оптимизации и моделирования ввиду своей универсальности и относительной простоты практической реализации. Однако большой проблемой при их использовании является преждевременная сходимость вычислительного алгоритма вследствие неполного исследования пространства поиска. Это происходит в том случае, когда все частицы попадают в область первого обнаруженного, возможно, локального оптимума, и не могут из нее выбраться. Для решения этой проблемы необходима разработка управляющих процедур, корректирующих перемещение особей в популяции.

В статье предлагается адаптивная модификация метода роя частиц, позволяющая осуществлять динамическое изменение траектории движения частиц для нахождения наиболее перспективных локаций. В основе метода лежит возможность изменения вектора перемещения индивидуально для каждой частицы, в зависимости от результативности выполнения предыдущей итерации. Для этого в предлагаемую модификацию канонического метода добавлены процедуры выбора направления и динамического изменения свободных параметров движения частицы. В отличие от канонической версии роевого алгоритма, в котором все особи популяции стремятся приблизиться к одной частице с наилучшим найденным значением, в новой модификации каждая частица самостоятельно выбирает направление движения и может изменить его в случае, если оно будет признано неэффективным. Такой подход позволяет снизить вероятность преждевременной сходимости алгоритма и лучше исследовать заданную область поиска, что особенно важно для многоэкстремальных функций со сложным рельефом. Предложенный метод был проверен на стандартном наборе тестовых функций непрерывной оптимизации и показал высокую эффективность при относительно небольших затратах времени и вычислительных ресурсов.
\end{abstract}

Ключевые слова: оптимизация, эволюционные алгоритмы, метод роя частиц, преждевременная сходимость, адаптация алгоритма, гибридизация алгоритмов.

Цитирование: Minaeva Yu.V. Adaptive modification of the particle swarm method based on dynamic correction of the trajectory of movement of individuals in the population // Business Informatics. 2016. No. 4 (38). P. 52-59. DOI: $10.17323 / 1998-0663.2016 .4 .52 .59$. 


\section{Литература}

1. Kennedy J., Eberhart R.C. Particle swarm optimization // Proceedings of the IEEE International Conference on Neural Networks (ICNN`95), 27 November - 01 December 1995, Perth, Australia. Vol. 4. P. 1942-1948.

2. Карпенко А.П., Селиверстов А.П. Глобальная безусловная оптимизация роем частиц на графических процессорах архитектуры CUDA // Наука и образование: Электронное научно-техническое издание. 2010. №4. [Электронный ресурс]: http:// technomag.edu.ru/doc/142202.html (дата обращения: 01.07.2016).

3. Yang C., Simon D. A new particle swarm optimization technique // Proceedings of the 18th International Conference on Systems Engineering (ICSEng 05 ), 16-18 August 2005, Las Vegas, USA. P. 164-169.

4. Xie X., Zhang W., Yang Z. Adaptive particle swarm optimization on individual level // Proceedings of the 6th International Conference on Signal Processing (ICSP'02), 26-30 August 2002, Beijing, China. P. 1215-1218.

5. Mendes R., Kennedy J., Neves J. The fully informed particle swarm: Simpler, maybe better // IEEE Transactions on Evolutionary Computation. 2004. Vol. 8. No. 3. P. 204-210.

6. Kennedy J., Mendes R. Population structure and particle swarm performance // Proceedings of the 2002 Congress on Evolutionary Computation (CEC'02), 12-17 May 2002, Washington, USA. P. 1671-1676.

7. Parsopoulos K.E., Vrahatis M.N. (Eds.) Particle swarm optimization and intelligence: Advances and applications. N.Y.: IGI Global, 2010.

8. Clerc M. Particle swarm optimization. London: ISTE, 2006.

9. Zhan Z., Zhang J., Li Y., Chung H.S.H. Adaptive particle swarm optimization // IEEE Transactions on Systems, Man, and Cybernetics. Part B. 2009. Vol. 39. No. 6. P. 1362-1381.

10. Ratnaweera A., Halgamuge S.K., Watson H.C. Self-organizing hierarchical particle swarm optimizer with time-varying acceleration coefficients // IEEE Transactions on Evolutionary Computation. 2004. Vol. 8. No. 3. P. 240-255.

11. Angeline P.J. Using selection to improve particle swarm optimization // Proceedings of the 1998 IEEE International Conference on Evolutionary Computation (ICEC'98). 4-9 May 1998, Anchorage, Alaska, USA. P. 84-89.

12. Chen Y.P., Peng W.C., Jian M.C. Particle swarm optimization with recombination and dynamic linkage discovery // IEEE Transactions on Systems, Man, and Cybernetics. Part B. 2007. Vol. 37. No. 6. P. 1460-1470.

13. Andrews P.S. An investigation into mutation operators for particle swarm optimization // Proceedings of the 2006 IEEE Congress on Evolutionary Computation, 16-21 July 2006, Vancouver, BC, Canada. P. 1044-1051.

14. Liang J.J., Suganthan P.N. Dynamic multi-swarm particle swarm optimizer with local search // Proceedings of the 2005 IEEE Congress on Evolutionary Computation (CEC'05), 2-5 September 2005, Edinburgh, Scotland. P. 522-528.

15. Gimmler J., Stützle T., Exner T.E. Hybrid particle swarm optimization: An examination of the influence of iterative improvement algorithms on performance // Proceedings of the 5th International Workshop "Ant Colony Optimization and Swarm Intelligence" (ANTS 2006), 4-7 September 2006, Brussels, Belgium. P. 436-443.

16. Jordan J., Helwig S., Wanka R. Social interaction in particle swarm optimization, the ranked FIPS, and adaptive multi-swarms // Proceedings of the 10th Annual Conference on Genetic and Evolutionary Computation (GECCO’08), 12-16 July 2008, Atlanta, USA. P. $49-56$. 


\title{
Concept for a new approach to project management in the activities of public servants ${ }^{1}$
}

\author{
Natalia F. Altukhova \\ Associate Professor, Head of Department of Business Informatics \\ Financial University under the Government of the Russian Federation \\ Address: 38, Scherbakovskaya Street, Moscow, 105187, Russian Federation \\ E-mail: nfaltuhova@fa.ru

\section{Elena V. Vasileva} \\ Professor, Department of Business Informatics \\ Financial University under the Government of the Russian Federation \\ Address: 38, Scherbakovskaya Street, Moscow, 105187, Russian Federation \\ E-mail: evvasileva@fa.ru
}

\section{Boris B. Slavin}

Scientific Advisor, Faculty of Applied Mathematics and Information Technology

Professor, Department of Business Informatics

Financial University under the Government of the Russian Federation

Address: 38, Scherbakovskaya Street, Moscow, 105187, Russian Federation

E-mail: bbslavin@fa.ru

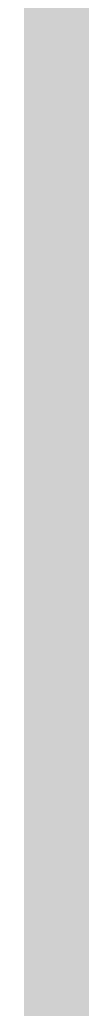

\begin{abstract}
This article presents the results of research into the possibility of adapting flexible methods of project management to the organization of activities of public servants of the Russian Federation and recommendations on combined approaches. The objectives of this research: to identify special aspects of project management in the public service and to evaluate the possibilities for adapting flexible methods of project management to the organization of activities of Russian public servants.

The activities of the public service are becoming increasingly innovative and intelligent and, as a consequence, less predictable. These days the public authorities are not only customers in relation to third organizations, but they themselves act as the direct executors of projects in the elaboration of development programs and legislative initiatives in the framework of executingorders of the President, Government and the higher state authorities. In these circumstances, management principles of the PMBOK and similar standards, which are strictly formalized and require clear planning of processes, no longer work. When the problems are large-scale, technologies are known, and the resources are defined, classical design techniques work flawlessly. But when any innovative goals are set, there may be high risk of exceeding budget funds and time; therefore in this case it is necessary to consider the feasibility of applying Agile-like technologies.

Possibilities for the combination of tough methods (in terms of responsibility and formalization) and flexible methods (in terms of goal-setting and continuity) of project management in the civil service were investigated using analysis of business processes and based on the results of a survey of the public servants participating in the implementation of certain tasks with respect to execution of public functions. It is noted that in contrast to the business-oriented organizations the government authorities are characterized by a significantly reduced motivation to informal leadership and undeveloped self-organization and selfmanagement. This fact imposes restrictions on the processes of implementing approaches of flexible
\end{abstract}

${ }^{1}$ This article was prepared based on the results of research carried with the support of government funds by the State Order of the University of Finance for the year of 2016 "Analysis of the best international practices of information support to realization of public functions. Development of proposals on improvement of information support to activities of civil public servants", state registration number AAAA-A16-116070610054-7 
project management in the activities of public servants, but it does not mean it is impossible to formulate and use them. Based on the results of the study we carried out, we determined principles of flexible project management in the civil service, the knowledge of which can be useful both for the public servants and businesses working with government agencies.

Key words: public servant, public administration, administrative reform, civil service efficiency, project management, new public management, business process.

Citation: Altukhova N.F., Vasileva E.V., Slavin B.B. (2016) Concept for a new approach to project management in the activities of public servants. Business Informatics, no. 4 (38), pp. 60-69.

DOI: 10.17323/1998-0663.2016.4.60.69.

\section{Introduction}

A mong the specific problems of the Russian system of performing public functions, we note the complexity and non-transparency of the processes, redundancy of documents, fuzzy distribution structure and duplication of responsibilities. The problem of interaction between the employees of civil services remains one of the most important. Meanwhile, the statistics show that the number of public servants is continuously increasing. Among other factors, during the period from 1999 to 2013, the number of employees of the state civil and municipal services of the Russian Federation increased 1.6 times [1].

In accordance with the data of the Russian Federal Service of State Statistics [1], the number of employees in government bodies, local self-government authorities and election commissions of municipal structures of the Russian Federation at the end of 2015 came to $2,176,400$ that is 1.87 times more than their number in 2000. The number of employees in the federal government bodies in 2015 came to $1,434,100$, and this is 2.75 times more than in the year of 2000. In 2015, 2,619,000 employees served in the government bodies of the constituent units of the Russian Federation, which is 1.35 times more than in 2000 .

A significant increase in the number of staff of the public administration means there is a need to establish a sustainable cooperation at various organizational levels, effective document management in the subdivisions, reduction of time spent (including time for paperwork) by eliminating low-productivity activities, pointless discussions, etc.

At the heart of the reform of public administration, many countries use the principles of new public management, or administration (NPM) [2, 3]. They are based on the conditions of transparency of public services, restructuring their work in accordance with mar- ket principles, including economic competition between them and with private organizations, material interest of employees in the economic returns from their actions, implementation of ideas of project management in the public administration with the goal of improving its efficiency and reducing expenditures. However, application of the project approach in the public sphere in the Russian Federation during the execution of some tasks has its own distinctive features and limitations.

\section{Assessment of the current situation in the field of project management of the civil service in Russia}

In the civil service, project technologies are usually considered in terms of the implementation of the classical PMBOK methodology (http://www.pmi.ru/). If we talk about the experience of implementing project approaches in the civil service, it is possible to give examples of reorganization and establishment of project offices in the regional government authorities (the Perm Territory, the Belgorod Region, and others). There has been established a Council for the implementation of project management in the federal bodies of the executive branch and the government authorities of the constituent units of the Russian Federation. For the third year in a row, we see the contest "Project Olympus" in the context of implementation of project management in the public sector (http://pmolimp.ru/). In the Tomsk Region, a large-scale project called"INOTomsk'2020"has been introduced to coordinate the government authorities, universities, large-scale businesses and public corporations based on the project approach. There are being established project offices at the level of the Federation constituent units and municipal structures. However, their number is limited to pilot testing of this approach: the results of the monitoring of project management in the bodies of the executive branch and companies with state participation in the year 2013 through project of- 
fices or comparable was found to be $38.5 \%$ of federal bodies of the executive branch and in $31.2 \%$ of the bodies of executive branch of Russian Federation constituent units [4].

At the moment, PMBOK is considered the most developed project management technology. The PMBOK body of rules focuses on the need for careful planning of project activities prior to starting their implementation. Such aspects as who is to participate in the project, how long the project is to last and how much money is required for its implementation are strictly formalized. The risks are assessed and measures to minimize them are taken. All project management procedures are preplanned over time. However, the universality and the large number of documents which describe specific situations make this standard very complicated, including for the understanding by those project participants (in this case by public servants) who do not have any special project training. Therefore, adaptation of this standard for a specific project and the specifics of the organization immediately and completely (and not on the individual chapters, which makes no sense) must be carried out by those who have never faced a problem of project management.As a result, the authors of many research investigations into Russian experience of the implementation of the PMBOK principles in the civil service point out the continuing disregard for the unification of presentation of project materials ("some of them are grouped in the integrated system of electronic document management... in the folders of corresponding functional-target blocks, and some - in the folders of individual public authorities" [5]), the continuing problems of duplication of functions of managers and participants in the project activities ("a new project office is being formed, but there is a ministry that is already solving similar tasks" [6]), as well as the complexity of adapting the principles of project management in the public authorities during evaluation of activity results and formation of the final or intermediate parameters of project performance.

In practice, the majority of public authorities supporting project management tasks use the simplest tools, among which are leading MS Word and MS Excel $(87.5 \%)$. At the same time, $7.7 \%$ of federal bodies of the executive branch and $18.8 \%$ of bodies of the executive branch of Russian Federation constituent units use MS Project [4] for scheduling. The general problem of interaction within the ministries consists in the persisting functional principle of its organization, in which it is easier to control to communicate. The main reason for the low rates of adaptation of project technologies in the civil service is the unpreparedness and lack of understanding by the public authorities than themselves of the benefits of project methodology. Such matters as distribution of rights and responsibilities in terms of interaction with the employees of various functional units of the organization, other administrative entities and bodies of other levels of the administrative authorities, use of outsourcing also by implementing organizations, are usually ignored. The formalization of the work of the public service during organization of project offices or project teams eventually becomes an uncontrollable and complicated process.

Modern trends in the development of the economy and society make public service activities more and more innovative and intelligent and, consequently, less predictable. Nowadays public authorities not only assign tasks to other organizations, but also act themselves as performers of projects in the elaboration of development programs and legislative initiatives. Where problems are complicated and large-scale, planning, of course, is necessary, and the application of classical project methods is justified. If there are high risks of exceeding the budgets and time limits, then the PMBOK standard, strictly formalized, providing clear planning of processes and actively introduced today in the civil service of the Russian Federation, ceases to work. In these circumstances, it is necessary to consider the feasibility of Agile-like technologies. Sometimes one should consider the possibility of combining tough methods (in terms of responsibility and formalization) and flexible methods (in terms of goal-setting and continuity) of project management. Meanwhile, nothing prevents breaking down a large-scale project so that some individual tasks could be implemented by an Agileteam. A flexible approach will make it possible to eliminate problem areas in the project management under the conditions of public service, and to consider the instability of the organizational structure, the need for regular meetings, as well as the unwillingness of the team to keep documentation in high demand in the preservation of the project information for analysis and optimization of the company activities.

\section{Analysis of conditions \\ of informational support of project activities of public servants in Russian organizations}

In the course of the research assessing the state of informational support to performance of public functions, the authors conducted a survey of public servants and employees of subordinated institutions, including administrative boards and the State-Financed Entity "Zhilischnik" of the districts of Moscow and the Moscow Region, the prefecture of one of the districts of Moscow, the Department of Information Technologies 
in the field of the state and municipal financial management and informational support of the budgeting process of the RF Ministry of Finance, as well as some other state organizations. In total, within the framework of our investigation 260 public servants were surveyed. We analyzed various versions of mutual work for solving common tasks, goal-achieving monitoring and team management. We determined the number of projects in which, as a rule, the employees participate at the same time, the volume of urgent and non-urgent tasks to be solved. Wealso considered problems of exceeding working time during the project execution, as well as the terms of automation of administrative processes.

The interview results have confirmed the selected common problems, including the presence of those projects that do not comply with deadlines. The average duration of the delay of the government projects in $33.85 \%$ of the cases was insignificant (up to $1-3$ days), but in $4.6 \%$ of the cases the civil service employees revealed delays for periods of up to one month.

In $11 \%$ of the cases, there was revealed a failure of short-term projects (with duration of up to one week), while such projects could be extended for a period of up to 3 days, and up to six months. The failed projects are characterized by overtime work of the employees. The results of our analysis of the questionnaires show that for the accomplishment of tasks in the projects that were extended for an insignificant period (from 3 days to 1 month), public servants in half of the cases worked after working hours at least once a week, and in $10 \%$ of the cases - every day. In the projects delayed up to six months, in $16.7 \%$ of the cases the civil service employees had to stay at work after working hours practically every other day. Moreover, the survey results have shown that the overtime work is noted by all the employees, regardless of the fact whether the project time limits fail or not.

Analysis has shown that the overwhelming number of business processes in organizations are described, but mostly only document flow for the incoming documents is automated: official correspondence with the higher and lower-level authorities, subordinated institutions, complaints of citizens and organizations, correspondence between the departments. Among the list of possible tools for describing and modelling administrative processes, the document flow for the incoming documents was mentioned by the employees of civil services in $38.2 \%$ of the cases. There is partially automated interaction with the Federal Treasury and banks ( $9 \%$ of the whole number of all the selected tools for automatization of business processes), with suppliers of goods, works and services in the process of concluding government contracts (12.7\%), and with multifunctional centers providing public and municipal services (MFC) to provide services to citizens (10.4\%). Apart from that, the respondents have noted the application of project management automation instruments (9\% of the total number of responses). Such processes as internal coordination of drafts of government contracts, personnel management (planning of training, assessment of the effectiveness of activities), maintenance service (repair of equipment, furniture, air conditioners, etc.), innovation management (submission of proposals, assessment, monitoring of implementation) are not automated or automated only partially (Table 1).

Program products for description and modeling of administrative processes used in the organizations

\begin{tabular}{l|c}
\multicolumn{1}{c|}{ Tools } & $\begin{array}{c}\text { Share in the total number } \\
\text { of investigated organizations }\end{array}$ \\
$\begin{array}{l}\text { Document flow for incoming documents (official correspondence with higher and lower-level authorities, } \\
\text { subordinated institutions, complaints of citizens and organizations, correspondence between the departments) }\end{array}$ & $38.2 \%$ \\
\hline Interaction with suppliers of goods, works and services in the process of concluding government contracts & $12.7 \%$ \\
\hline Interaction with the MFC ("My Documents") to provide services to citizens & $10.4 \%$ \\
\hline Interaction with the Federal Treasury and the banks & $9.0 \%$ \\
\hline Project management & $9.0 \%$ \\
\hline Internal coordination of drafts government contracts & $8.8 \%$ \\
\hline Human resources management (planning of training, assessment of performance of activities) & $6.0 \%$ \\
\hline Maintenance service (repair of equipment, furniture, air conditioners, etc.) & $2.8 \%$ \\
\hline Innovation management (submission of proposals, evaluation, monitoring of realization) & $2.4 \%$ \\
\hline Others & $0.8 \%$ \\
\hline
\end{tabular}


As our investigation of the current situation has demonstrated, there is a particularly acute problem the civil service managing knowledge and competences. The results of the survey carriedout have shown that information about a project's progress, as a rule, is not accumulated, and the electronic archive is kept in $45.6 \%$ of the cases. A project background is createdin only $34 \%$ of the cases, and a project folder on the portal is even rarer $(20.16 \%)$. Information about the people involved in the project is stored in electronic form only in $47 \%$ of the cases, and in $30 \%$ it remains on paper-based media. This means that the employees understand the importance of saving intermediate information about the project, but they do not have any adequate tools for their collection, storage and current and future shared use.

Any new knowledge gained by the employees in the process of advanced vocational training and additional training is not transferred to their colleagues. Only $2 \%$ of the interviewed public servants have responded that their professional knowledge is quite enough for their work, while more than $40 \%$ were not sure of this. A majority of respondents (76\%) mentioned competence assessment as an effective tool for assessing the competence of public servants. In their point of view, the most important factors in the selection and promotion of staff to senior positions in the organization are professional and personal qualities, as well as work experience $(60 \%$ and $50.5 \%$, respectively). At the same time, they place a very low value on such factors as authority in the team $(25 \%)$ and personal desire $(23 \%)$. Selection was made for the most strongly sought-for competences, such as general professional $(81.9 \%)$ and regulatory competences $(80 \%)$ and, with a slight difference, competences in the performance and efficiency of work $(72.4 \%)$. The least popular turned out to be a group of competences "change management" (14.3\%), which is not surprising, because the business processes of public authorities are established "from top down", and working documents of the higher levels of administration often have the status of regulatory documents. We also noted the low demand for the group of competencies of self-management and professional growth $(21.9 \%)$, which can be attributed to the shortcomings of the existing competence-based approaches in government institutions.

In general it can be concluded that the Russian system of public administration is in a transitional state from the first (base) level to the second level (repeated practices), in accordance with the assessment model of the maturity level of management processes with the help of the Capability Maturity Model (CMM) meth- odology (http://www.sei.cmu.edu/cmmi/): bringing administrative processes under regulation, defining efficiency indicators, availability of project controlling systems, general project management methodology and project management training programs for public servants. However, the processes are insufficiently organized and there is no understanding by the employees themselves of the worth of control over achievement of the set goals, as well as of the importance of the information formalizing at each stage of implementation of tasks to be solved. As for the scope and completeness of use of electronic means in the activities of public servants and their cross-functional interaction, it is too early to talk about this [7].

\section{Principles for adapting flexible methods of project management to public service activities}

It should be noted that presently there are several project management techniques that have worked well in solving business problems. They can also be considered as a basis for improving the project activities of civil public servants in terms of their performance of public functions, along with the implementation of the classical PMBOK methodology. The activities of public servants are associated primarily with intellectual activity (preparation of orders, instructions, programs, etc.), and they are more like the work of programmers than that of builders or manufacturers. Therefore, we can actively discuss the application of such techniques and concepts such as the Total Quality Management (TQM), the quality management model of informationtechnology services (Information Technology Service Management, ITSM), Lean Manufacturing, and Six Sigma, a method of the "critical chain" for project management (Critical Chain Project Management, CCPM), Goldratt's theory of constraints (Theory of Constraints, TOC), easy or flexible (Agile) ITprojects management methods using principles of SCRUM, KANBAN, as well as the recently popular hybrid approach SCRUMBAN.

In our opinion, the problems of civil service which remain even after the implementation of the PMBOK principles show that it is impossible to limit the approach to reorganization of the public management system using the classical methodology, even if it has proved its worth. It is necessary to take into consideration the fact that during the process of execution of a project associated with implementation of public functions there are changes of the objectives, number and complexity 
Table 2.

Steps for transition to GovAgile methodology

\begin{tabular}{|c|c|c|c|c|}
\hline & $\begin{array}{l}\text { Principles of Agile } \\
\text { Manifesto }[\mathbf{9}, 10]\end{array}$ & $\begin{array}{l}\text { Principles for } \\
\text { projects in general }\end{array}$ & $\begin{array}{l}\text { Distinctive features } \\
\text { of the civil serviee }\end{array}$ & $\begin{array}{l}\text { GovAgile } \\
\text { prineiples }\end{array}$ \\
\hline 1 & $\begin{array}{l}\text { The highest priority is satisfaction of } \\
\text { customer's needs by the regular and early } \\
\text { delivery of valuable software }\end{array}$ & $\begin{array}{l}\text { The customer of the } \\
\text { project results should } \\
\text { receive them regularly } \\
\text { and rapidly }\end{array}$ & $\begin{array}{l}\text { In the civil service the customer } \\
\text { and sponsor is always the linear } \\
\text { head }\end{array}$ & $\begin{array}{l}\text { The project team members should } \\
\text { include those employees who are } \\
\text { linearly subordinate to the project } \\
\text { sponsor andthecustomer }\end{array}$ \\
\hline 2 & $\begin{array}{l}\text { Changing of requirements is welcome even at } \\
\text { the latest stages of development. The Agileuse } \\
\text { processes allow using changes to provide the } \\
\text { customer with a competitive advantage }\end{array}$ & $\begin{array}{l}\text { Do not be afraid to } \\
\text { change the goals } \\
\text { and objectives in the } \\
\text { process }\end{array}$ & $\begin{array}{l}\text { In the civil service, objectives } \\
\text { are often changing, but they } \\
\text { should be controlled }\end{array}$ & $\begin{array}{l}\text { The project objectives may be } \\
\text { changed by the head, but the } \\
\text { changes should be recorded }\end{array}$ \\
\hline 3 & $\begin{array}{l}\text { An operational product should be produced as } \\
\text { often as possible, at intervals of a couple of } \\
\text { weeks to a couple of months }\end{array}$ & $\begin{array}{l}\text { The results should } \\
\text { appear and be updated } \\
\text { frequently }\end{array}$ & $\begin{array}{l}\text { At all the stages, there should be } \\
\text { reporting parameters }\end{array}$ & $\begin{array}{l}\text { The project should be divided into } \\
\text { stages, each of which has a value } \\
\text { for the customer }\end{array}$ \\
\hline 4 & $\begin{array}{l}\text { Throughout the project, the developers and } \\
\text { business representatives must work together } \\
\text { on a daily basis }\end{array}$ & $\begin{array}{l}\text { The team members } \\
\text { and customers should } \\
\text { regularly discuss the } \\
\text { project }\end{array}$ & $\begin{array}{l}\text { In the civil service, there is } \\
\text { a routine practice of regular } \\
\text { reports, usually not more often } \\
\text { than once a week }\end{array}$ & $\begin{array}{l}\text { The manager must receive reports } \\
\text { about the project on a weekly } \\
\text { basis }\end{array}$ \\
\hline 5 & $\begin{array}{l}\text { The project should be elaborated by motivated } \\
\text { professionals. To accomplish the work, create } \\
\text { for them appropriate conditions, provide } \\
\text { support and fully trust them }\end{array}$ & $\begin{array}{l}\text { The team members } \\
\text { should be motivated } \\
\text { and have the appropri- } \\
\text { ate competences }\end{array}$ & $\begin{array}{l}\text { The team members should be } \\
\text { motivated and have the appropri- } \\
\text { ate competences }\end{array}$ & $\begin{array}{l}\text { The team members should be } \\
\text { motivated and be selected in ac- } \\
\text { cordance with their competences }\end{array}$ \\
\hline 6 & $\begin{array}{l}\text { Direct communication is the most practical } \\
\text { and efficient way to exchange information } \\
\text { both with the team itself and within the team }\end{array}$ & $\begin{array}{l}\text { Personal communica- } \\
\text { tion of team members } \\
\text { is obligatory }\end{array}$ & $\begin{array}{l}\text { Regular meetings of team } \\
\text { members are obligatory }\end{array}$ & $\begin{array}{l}\text { The team members should meet } \\
\text { each other in person at least twice } \\
\text { a week }\end{array}$ \\
\hline 7 & $\begin{array}{l}\text { The operational product is the main indicator } \\
\text { of progress }\end{array}$ & $\begin{array}{l}\text { Everything must be } \\
\text { subordinated to the } \\
\text { results }\end{array}$ & $\begin{array}{l}\text { For the civil service control is of } \\
\text { great importance }\end{array}$ & $\begin{array}{l}\text { Stages of the project and the value } \\
\text { of their results should coincide } \\
\text { with measurable parameters }\end{array}$ \\
\hline 8 & $\begin{array}{l}\text { The investors, developers, and users should } \\
\text { be provided with a possibility to maintain a } \\
\text { constant rhythm. Agile helps to establish such } \\
\text { a sustainable development process }\end{array}$ & $\begin{array}{l}\text { Constant rhythm of the } \\
\text { project management is } \\
\text { obligatory }\end{array}$ & $\begin{array}{l}\text { Regularity of reports dictates } \\
\text { the rhythm of work }\end{array}$ & $\begin{array}{l}\text { Stages of the project should have } \\
\text { approximately the same duration } \\
\text { and to be short (no more than one } \\
\text { quarter) }\end{array}$ \\
\hline 9 & $\begin{array}{l}\text { Continuous attention to technical perfec- } \\
\text { tion and quality of the project development } \\
\text { improves flexibility of the project }\end{array}$ & $\begin{array}{l}\text { Continuous techni- } \\
\text { cal improvement is } \\
\text { obligatory }\end{array}$ & $\begin{array}{l}\text { Continuous technical } \\
\text { improvement is obligatory }\end{array}$ & $\begin{array}{l}\text { Use of innovations in the project } \\
\text { should be encouraged }\end{array}$ \\
\hline 10 & $\begin{array}{l}\text { Simplicity (the art of minimizing unnecessary } \\
\text { work) is needed urgently }\end{array}$ & $\begin{array}{l}\text { Search for simple } \\
\text { solutions }\end{array}$ & $\begin{array}{l}\text { It will require a lot of efforts from } \\
\text { the public servants; they are not } \\
\text { looking for simple solutions }\end{array}$ & $\begin{array}{l}\text { The solutions should be simple } \\
\text { and elegant }\end{array}$ \\
\hline 11 & $\begin{array}{l}\text { Self-organizing teams give rise to the best } \\
\text { requirements, architectural and technical } \\
\text { solutions }\end{array}$ & $\begin{array}{l}\text { Self-organization is } \\
\text { obligatory }\end{array}$ & $\begin{array}{l}\text { It will require a lot of efforts from } \\
\text { the public servants; they are not } \\
\text { used to initiative }\end{array}$ & $\begin{array}{l}\text { It is necessary to motivate initia- } \\
\text { tive and self-organization }\end{array}$ \\
\hline 12 & $\begin{array}{l}\text { The team must systematically analyze the } \\
\text { possible ways to improve efficiency and to } \\
\text { adjust their work style }\end{array}$ & $\begin{array}{l}\text { Improvements should } \\
\text { be continuous }\end{array}$ & $\begin{array}{l}\text { Improvements should be } \\
\text { continuous }\end{array}$ & $\begin{array}{l}\text { It is necessary to make the project } \\
\text { approach be process-relevant and } \\
\text { complywith ISO } 9001\end{array}$ \\
\hline
\end{tabular}

of the tasks, and priorities. In these circumstances, the principles of management should be replaced with the new ones. Different tasks require different approaches, sometimes in conditions of their combinations based on the specific character of sub-tasks. Different conditions of project implementation also make it necessary to apply different tools. In cases where the problems are large- scale, the technologies are known and the resources are defined, the classical project techniques work flawlessly. But when innovative objectives are set, and high risks of exceeding the limits of budgets and time take place, it is necessary to consider the feasibility of applying flexible technologies (in combination with tough technologies or separately). 
In addition, the participation of public servants in projects should match their competencies. Some employees work better using tough technologies, while others work better using flexible technologies, and still others should be generally used in the processes only involving them in fulfillment of single orders - not difficult ones, but, nevertheless, of top priority. Therefore, the authors have formulated the necessity for developing new principles, taking into consideration both the possibilities of flexible project management and rigorous requirements of responsibility on the part of the civil service. These principles include the best practices of application of PMBOK management principles and Agile methodologies for flexible management of the project team of the civil service under conditions of maintaining rigorous requirements on responsibility and formalization of processes.

Flexible methodology focuses on the use of interactive development, dynamic formation of requirements and ensuring their implementation resulting from the continuous interaction within the self-organizing working groups, consisting of experts in various fields [8]. The principles of the Agile methodology [9, 10] are as follows: to pay attention to communication within the team, thus reducing the number of official written documents; to continuously discuss any emerging problemsof the solution being developed and to be prepared for its complete change regardless of the initially intended plan. Just this fact has recently drawn the attention of experts in project management to Agile not only in the field of software development, but also when conducting projects in business and organizations. This makes the given technology of management interesting for implementation in civil service projects. From the flexible methodology of development, SCRUM [11], for the civil service there are valuable principles of cooperation and discussion of all the changes. Thus, the project team could effectively discuss what they have done for a certain period, which errors have occurred on the way, how they could possibly be corrected and what is planned next. But the SCRUM, as an individually functioning methodology, cannot provide maximum performance of the project team, and therefore it requires additional tools and review of current problems for the purpose of time release. Today in those projects that provide for the creation of a software product by small groups and within a limited time it has been decided to combine flexible methodologies SCRUM and KANBAN [12]. For such an integrated approach, there has even appeared a new term: SCRUMBAN [13]. However, in contrast to the appli- cation of flexible technologies in business, civil service projects should be based not only on the international experience of implementation, but to take into consideration national peculiarities.

The study of distinctive features of project management in the civil service and assessment of the possibility of adapting the flexible methods of project management to the organization of work of public servants in the Russian Federation have allowed the authors to formulate GovAgile principles - the principles of flexible project management in the civil service. Table 2 shows the steps of sequential transition from Agile in software development to Agile in business and Agile in the civil service.

In general, in the field of project management it is necessary to apply a subject-oriented approach which takes into consideration special abilities of the employee. The project approach is to be customer-oriented; it should comprise the tools of continuous improvement, and the employees should be motivated to achieve it. The framework of the project approach requires expanding the standards of activities of public servants with due consideration of flexible methods of project management in cases where the result has an innovative character. Moreover, the time management system should set provisions for implementation of the priority assignments.

\section{Conclusion}

The task of organizing effective interaction between civil service employees is very important. Continuing challenges of the public service show that it is impossible to limit the approach to reorganization of the public management system using only the PMBOK. During the process of implementing the project approach and management by objectives for the realization of public functions by civil public servants, one must also apply and adapt the principles of various management methodologies, including flexible methodologies.

In consequence of the research we carried out, we revealed certain problem areas of activities of civil public servants during the implementation of public functions. This is, above all, a low level of automation of business processes. As a rule, there are systems of document flow automation and means of interaction with the suppliers and financial organizations. In the process of performing public functions, some projects fail; work of the staff after the working hours is commonly observed. Not withstanding the fact that the employees recognize the importance of maintaining the project information, it 
usually remains only on paper-based media. Apart from that, there remains the problem of knowledge management in the civil service. The Russian system of public administration is characterized by availability of a project design work monitoring system and a project management training program for public servants. However, there remains the undecided question about the readiness of the federal and regional authorities themselves for internal reforms, and the readiness of public servants to change perceptions about their personal responsibility for the implementation of projects.

The steps of sequential transition from Agile in development of information systems and business to application of the GovAgile methodology in the civil service are formulated. Possibilities of combining tough and flexible project management methods in the civil service have been investigated based on analysis of business processes and in accordance with the results of a survey of public servants involved in the implementation of certain tasks relating to the execution of public functions. We noted that, in contrast to the business-oriented organizations, motivation of informal leadership in the government authorities is significantly reduced, and self-organization and self-management are not developed.

Analysis of the results of interviewing public servants has revealed the specific character of the civil service which should be kept in mind when implementing Agile in project management. For example, the project customer and sponsor in Agile wording is always the linear head, the prevailing function is controlling, and initiative itself is suppressed. All these factors impose restrictions on the processes of implementing the flexible project management approaches in the activities of public servants, but they do not mean it is impossible to formulate and use them.

\section{References}

1. Federal State Statistics Service (2016) State, public organizations. Available at: http://www.gks.ru/wps/wcm/connect/rosstat_main/rosstat/ $\mathrm{ru} /$ statistics/state (accessed 01 August 2016) (in Russian).

2. Sivintseva O.V. (2013) Instrumenty NPM v institutsional'noy srede sovremennogo Kitaya [NPM instruments in the institutional environment of modern China]. ArsAdministrandi, no. 4, pp. 89-101 (inRussian)

3. Obolonsky A.V. (2002) Byurokratiya dlya XXI veka? Modeli gosudarstvennoy sluzhby - Rossiya, SShA, Angliya, Avstraliya [Bureaucracy for the 21 st century? Models of public service - Russia, USA, England, Australia]. Moscow: Delo (inRussian).

4. Zolochevskaya E.Yu., Krivosheeva T.D. (2014) Funktsional'naya kharakteristika rossiyskoy sistemy upravleniya gosudarstvennymi proektami [Functional characteristic of Russian public project management system]. Management Issues, no. 6, pp. 42-49 (in Russian).

5. Krasilnikov D.G., Yakimova M.N. (2011) Standart PMBOK i proektnoeupravlenie v organakh gosudarstvennoy vlasti Permskogo kraya: priblizhenie $\mathrm{k}$ idealu[PMBOK standard and project management in public authorities of Perm Region: an approximation to the ideal]. ArsAdministrandi, no. 3, pp. 44-54 (in Russian).

6. Vodopyanov V. (2010) Povtornyy prem'ernyy pokaz [Repeatedpremiere]. Commersant.ru, 16 November 2010. Available at: http://www.kommersant.ru/doc/1540468/print (accessed 12 November 2016) (in Russian).

7. Ivanov V.V., Korobova A.N. (2016) Gosudarstvennoe i munitsipal'noe upravlenie s ispol'zovaniem informatsionnykh tekhnologiy [Public and municipal management using information technologies]. Moscow: INFRA-M (inRussian).

8. Rechkalov V. (2015) Agile i Kriticheskaya tsep' [Agile and Critical path]. TOCPEOPLE. Community of theory of constraints. Available at: http://tocpeople.com/2015/11/agile-i-kriticheskaya-cep/ (accessed 10 March 2016) (in Russian).

9. Beck K., Beedle M., van Bennekum A., et al. (2001) Manifesto for Agile software development. Available at: http://www.agilemanifesto.org (accessed 16 May 2016).

10. Real ITSM (2015) 10 aspektov Agile Development ot Gartner [10 aspects of Agile Development from Gartner]. Available at: http://www.realitsm.ru/2015/07/10-aspektov-agile-development-ot-gartner/ (accessed 16 May 2016) (in Russian).

11. Sutherland J. (2016) SCRUM. Revolyutsionnyy metod upravleniya proektami [SCRUM. A revolutionary method of project management]. Moscow: Mann, Ivanov and Ferber (in Russian).

12. Japan Management Association (2014) Kanban i tochno vovremya na Toyota: Menedzhment nachinaetsya na rabochem meste [Kanban and Just-in-Time at Toyota: Management begins at the workplace]. Moscow: Alpina Publisher (in Russian).

13. Sibiriks (2016) Scrumban. Rukovodstvo pol'zovatelya [Scrumban. Users' manual]. Available at: http://scrumban.helpdesk.sibirix.ru/docs/ scrumban/scrumban-manual.pdf(accessed 11 November 2016) (in Russian). 


\title{
Концепция нового подхода к управлению проектами в деятельности государственных служащих²
}

\author{
Н.Ф. Алтухова \\ кандидат экономических наук, заведующая кафедрой бизнес-информатики \\ Финансовый университет при Правительстве РФ \\ Адрес: 105187, г. Москва, ул. Щербаковская, д. 38 \\ E-mail:nfaltuhova@fa.ru
}

\section{Е.В. Васильева}

доктор экономических наук, профессор кафедры бизнес-информатики Финансовый университет при Правительстве РФ Адрес: 105187, г. Москва, ул. Щербаковская, д. 38 E-mail: evvasileva@fa.ru

\section{Б.Б. Славин}

кандидат физико-математических наук научный руководитель факультета прикладной математики и информационных технологий профессор кафедры бизнес-информатики Финансовый университет при Правительстве РФ Адрес: 105187, г. Москва, ул. Щербаковская, д. 38

E-mail: bbslavin@fa.ru

\section{Аннотация}

В статье представлены результаты исследования возможности адаптации гибких методов проектного управления к организации работы государственных служащих РФ, даны рекомендации по сочетанию различных подходов. Цели исследования - выявить особенности проектного управления в государственной службе и оценить возможности адаптации гибких методов проектного управления к организации работы государственных служащих России.

Деятельность государственной службы становится все более инновационной и интеллектуальной и, как следствие, менее предсказуемой. Органы государственной власти сегодня выступают не только в роли заказчиковпо отношению к сторонним организациям, но и сами являются непосредственными исполнителями проектов в области разработки программ развития и законодательных инициатив, в рамках выполнения поручений Президента, Правительства и вышестоящих инстанций. В этих условиях принципы управления РМВОКи аналогичных стандартов, которые строго формализованы и предполагают четкое планирование процессов, перестают работать. Там, где задачи являются масштабными, технологии известны, а ресурсы определены, классические проектные методики действуют безупречно. Если же ставятся новаторские цели, то возникают высокие риски превышения бюджетов и времени, поэтому в этом случае необходимо рассматривать целесообразность применения Agile-подобных технологий.

Возможности сочетания жестких (с точки зрения ответственности и формализации) и гибких (с точки зрения целеполагания и непрерывности) методов управления проектами в госслужбе исследовались на основе анализа бизнес-процессов и по результатам опроса государственных служащих, участвовавших в реализации тех или иных задач по исполнению государственных функций. Отмечено, что, в отличие от бизнес-ориентированных организаций, в органах государственной власти существенно снижена мотивация к неформальному лидерству, не развиты самоорганизация и самоменеджмент. Это накладывает ограничения на процессы внедрения подходов гибкого проектного управления в деятельности госслужащих, но не означает невозможность их формулирования и использования. На основе результатов проведенного исследования определены принципы гибкого проектного управления в госслужбе, знание которых может быть полезным как для самих госслужащих, так и для бизнеса, работающего с государственными структурами.

Ключевые слова: государственный служащий, государственное управление, административная реформа, эффективность государственной службы, управление проектами, новый государственный менеджмент, бизнес-процесс.

Цитирование: Altukhova N.F., Vasileva E.V., Slavin B.B. Concept for a new approach to project management in the activities of public servants// Business Informatics. 2016. No. 4 (38). P. 60-69. DOI: 10.17323/1998-0663.2016.4.60.69.

\footnotetext{
2 Статья подготовлена по результатам исследований, выполненных за счет бюджетных средств по Государственному заданию Финансового университета 2016 года «Анализ лучших зарубежных практик информационного обеспечения реализации государственных функций. Разработка практик информационного обеспечения реализации государственных функций. Разработка гражданских служащих», номер государственной регистрации АААА-А16-116070610054-7.
} 


\section{Литература}

1. Федеральная служба государственной статистики России. Государство, общественные организации [Электронный ресурс]: http://www.gks.ru/wps/wcm/connect/rosstat_main/rosstat/ru/statistics/state (дата обращения 01.08.2016).

2. Сивинцева О.В. Инструменты NPM в институциональной среде современного Китая // ArsAdministrandi. 2013. № 4. C. 89-101.

3. Оболонский А.В. Бюрократия для XXI века? Модели государственной службы - Россия, США, Англия, Австралия. М.: Дело, 2002. 165 c.

4. Золочевская Е.Ю., Кривошеева Т.Д. Функциональная характеристика российской системы управления государственными проектами // Вопросы управления. 2014. № 6. С. 42-49.

5. Красильников Д.Г., Якимова М.Н. Стандарт РМВОК и проектное управление в органах государственной власти Пермского края: приближение к идеалу // ArsAdministrandi. 2011. № 3. С. 44-54.

6. Водопьянов В. Повторный премьерный показ // Коммерсант.ru, 16.11.2010 [Электронный pecypc]: http://www.kommersant.ru/ doc/1540468/print (дата обращения: 12.11.2016).

7. Иванов В.В., Коробова А.Н. Государственное и муниципальное управление с использованием информационных технологий. М.: ИНФРА-М, 2016. $382 \mathrm{c}$.

8. Речкалов B. Agile и Критическая цепь // TOCPEOPLE. Сообщество теории ограничений [Электронный ресурс]: http://tocpeople. com/2015/11/agile-i-kriticheskaya-cep/ (дата обращения: 10.03.2016).

9. Manifesto for Agile software development / K. Beck [et al.].[Электронный ресурс]: http://www.agilemanifesto.org (дата обращения: 16.05.2016).

10. 10 аспектов AgileDevelopment от Гартнер // Real ITSM, 21.07.2015 [Электронный pecypc]: http://www.realitsm.ru/2015/07/ 10-aspektov-agile-development-ot-gartner/ (дата обращения: 16.05.2016).

11. Сазерленд Дж. SCRUM. Революционный метод управления проектами. М.: Манн, Иванов и Фербер, 2016.288 с.

12. Канбан и точно вовремя на Тоуота: Менеджмент начинается на рабочем месте. М.: Альпина Паблишер, 2014.214 с.

13. Scrumban. Руководство пользователя [Электронный pecypc]: http://scrumban.helpdesk.sibirix.ru/docs/scrumban/scrumban-manual. pdf (дата обращения: 11.11.2016). 


\title{
Decision making using a combination of management accounting and an expert approach
}

\author{
Dmitry V. Isaev \\ Associate Professor, Department of Business Analytics \\ National Research University Higher School of Economics \\ Address: 20, Myasnitskaya Street, Moscow, 101000, Russian Federation \\ E-mail:disaev@hse.ru
}

Abstract

This paper focuses on the questions of combining management accounting and an expert approach for decision making in the sphere of economics and management. The background of such a combination is that within both approaches there are a decision making goal, a set of alternatives and criteria for their assessment, as well as the possibility of multivariate evaluation of the alternatives for different possible situations.

The basic decision making processes provide similar data processing. Their scope relies on classification of assessment criteria into three types: quantitative criteria, for which source information for management accounting is available, quantitative criteria with lack of source information for management accounting, and qualitative criteria, for which management accounting methods are not applicable. Relying on such classification, four basic processes are defined: pure management accounting, management accounting supplemented by estimates according to predefined rules, management accounting supplemented by expert estimates, and the pure expert approach.

Relying on different basic processes, fifteen working processes (including the generalized working process including all four basic processes) are defined. Conclusions are made regarding the practical applicability of different working processes, depending on the scope of decision making criteria.

Approval of the combined approach is performed with the help of an example of investment appraisal relating to a manufacturing company's development, using three classic management accounting criteria (payback period, net present value, internal rate of return), and three criteria of a qualitative nature.

Key words: decision making, management accounting, expert approach, assessment of alternatives, investment appraisal, analytic hierarchy process.

Citation: Isaev D.V. (2016) Decision making using a combination of management accounting and an expert approach. Business Informatics, no. 4 (38), pp. 70-78. DOI: 10.17323/1998-0663.2016.4.70.78.

\section{Introduction}

$\mathrm{M}$ odern business often faces various decision making tasks - selecting one of alternative courses of action. One of the approaches to decision making is management accounting, which deals with the collection, processing and presentation of relevant financial and economic information. Classic examples of decision making using management accounting are the selection of activity level and product mix, decisions regarding stopping production 
or replacing some products, "make or buy" decisions, justification of further processing of joint products, as well as investment appraisals [1-3].

An important feature of management accounting is that it deals with financial and economic calculations which allow us to compare alternatives from the point of view of costs and economic benefits. However, under conditions of incompleteness and unreliability of source information, as well as in cases when qualitative or semi-structured information is essential, management accounting becomes inapplicable.

Another way of decision making is the expert approach, which involves one or few experts who evaluate alternatives according to certain criteria, relying on their knowledge, experience and management intuition. In the case of group decision making, special coefficients representing differences in the experts' competences may be applied. Forming expert estimates and their further processing may be performed by various decision making methods, such as the analytic hierarchy process and the analytic network process [4-6], methods of the ELECTRE family [7], methods of the PROMETHEE family [8-10] and some others. Processing of expert estimates often requires quite complex mathematical calculations, so there is a special class of information systems - decision support systems [11].

Both approaches are widely represented in academic and business literature, and successfully applied in practice. However, the two approaches are always considered separately. At the same time, quite often multicriteria decision making tasks arise, where for some criteria management accounting is applicable, while for other criteria only the expert approach may be used. That is why there a question arises about the possibility of combining management accounting and the expert approach within common decision making processes.

\section{Decision making using the management accounting and expert approaches: Similarities and differences}

For answering the question about the possibility of combining the management accounting and an expert approach an analysis of their similarities and differences is essential. It is reasonable to conduct such an analysis on the basis of various aspects, such as objectives of the approaches and their areas of use, source information ant its origin, methods of assessing alternatives and the degree of their objectivity, the number of criteria, and the possibility of multivariate (situational) analysis.
As already noted, the objective of both approaches is evaluation of alternatives and selecting one of them as the most preferable. While management accounting is applicable only in the field of economics and management, the expert approach has a much wider area of use: it may be used in very different fields of human activity, including education, medicine, ecology, and politics.

Regarding source information, management accounting deals with quantitative (first of all, financial) information, which is well structured. Such information may come from multiple internal and external sources - the accounting systems of an enterprise, corporate reporting of an enterprise and external organizations, statistical databases, analytical reviews, etc. Management accounting information is quite reliable; however, in the case of lack or insufficient source data reliability estimated values may be used.

Within the expert approach, any relevant information including qualitative and semi-structured information may be used. Sources of such information may be very different, being situated either inside or outside an enterprise. The scope of information for the expert approach may be much wider than the scope of information for management accounting. Some information may be known to certain experts, but unknown to other experts and moderators of the assessment. In addition, when evaluating an alternative, each expert may use his personal tacit knowledge, experience, vision and intuition.

From the point of view of the ways of evaluating alternatives, management accounting uses the results of calculations, expressed in financial an economic terms. The expert approach deals with expert estimates, which may be expressed in different scales (scoring, ordinal), or via preferences in some other form (for example, the analytic hierarchy process includes pairwise comparisons based on the verbal-numerical fundamental scale).

Management accounting aspires to the best possible objectivity, so rough values are applied only in rare cases, when objective information is not available or is not reliable enough. As to the expert approach, it is initially oriented to collection and consolidation of the subjective opinions of experts, with additional analysis of concordance of such estimates.

Regarding the number of criteria, most management accounting tasks deal with a single criterion. For example, selection of the activity level uses such a criterion as the relation between marginal profit and fixed costs, product mix selection - marginal profit per unit of limiting factor, justification of discontinuing or replacing 
products - the difference between price and production cost, etc. However, in some cases several criteria may be used, but without generalizing the results obtained for different criteria. For example, for investment appraisal such criteria as accounting rate of return, payback period, net present value or internal rate of return are applicable.

Within the expert approach, either one, or several criteria may be used (in the latter case there is a multicriteria decision making task [12]). If criteria have different significance, special weights may be assigned to them. In all cases, in multicriteria tasks formal rules of generalizing expert estimates by criteria are applied.

From the point of view of situational analysis, management accounting makes possible multivariate calculations, depending on decision making situations (first of all, the projected state of the external environment) and, accordingly, relying on different source data sets. However, no formal rules for generalizing results by situations are considered within management accounting.

The expert approach also permits one to consider different situations, but with the use of formal rules for generalizing the results. The probabilities of occurrence may be assigned to situations (directly or by ranking), or one may consider that decision is to be made under uncertainty.

So, both management accounting and the expert approach imply the availability of some set of alternatives and criteria for their assessment that arise from the decision making goal. Both approaches also permit multivariate assessment of the alternatives, depending on possible situations. Such common features of management accounting and the expert approach may be considered as a background for their combination within decision making processes. At the same time, there are such specific features of the expert approach as availability of experts, as well as evaluating alternatives in abstract terms, rather than using financial and economic measures. In turn, these particularities lead to differences in methods of generalizing estimates by experts, criteria and situations.

\section{Combining the management accounting and expert approaches: Basic and working decision making processes}

Decision making processes may be subdivided into basic and working processes. Within basic processes, source information is processed similarly, while within working processes source information may be processed in different ways. Working processes are defined relying on the basic ones: each working process may be equal to one of the basic processes, or include a combination of some of them.

Any decision making process (both basic and working) starts with a conceptual statement of a decision making task (goal, alternatives, criteria, etc.) and ends with final consideration of the results obtained (as a rule, in the forms of discussions or meetings, with the participation of all the stakeholders) and the final decision making.

Definition of the basic processes relies on classification of criteria used for assessing alternatives. First of all, criteria are subdivided into quantitative and qualitative. In addition, for quantitative criteria source information for management accounting calculations may be either available, or not. Thus, the criteria may be subdivided into three types:

1. Quantitative criteria for which source information for management accounting calculations is available;

2. Quantitative criteria for which source information for management accounting calculations is not available;

3. Qualitative criteria for which management accounting methods are inapplicable.

Assessment of the alternatives with respect to criteria of types 2 and 3 may be executed only using the expert approach. As to criteria of type 1, it is possible to apply management accounting calculations, and in addition their results may become the subject of a subsequent expert assessment.

Classification of criteria allows us to determine four basic processes:

BP 1 - pure management accounting. After the conceptual statement of a task, one selects the relevant management accounting method, then the appropriate source information is collected. The results of management accounting calculations become the basis for ranking the alternatives and are presented for final consideration and decision making without any additional expert assessment. Such a basic process is applicable for the criteria of type 1 ;

$\checkmark$ BP 2 - management accounting supplemented by rules-based estimates. After the conceptual statement of a task, selecting the relevant management accounting method and collecting appropriate source information, the calculations are performed. Then the results of management accounting calculations are transformed into estimates according to predefined rules, without any additional expertise. Since the transformation rules are determined in an expert way (although a priori, regardless 
of the management accounting results), such estimates, in fact, also arise from the expert approach. On this basis, ranking the alternatives, and then - final consideration and decision making are executed. This basic process is also applicable for the criteria of type 1;

^ BP 3 - management accounting supplemented by expert estimates. After the conceptual statement, selecting the management accounting method and collecting appropriate source information, the calculations are executed. The results of management accounting calculations are subject to additional expert assessment. Then the expert estimates become involved in subsequent calculations using one of decision making methods. After this, ranking of alternatives, final consideration and decision making are executed. Like BP 1 and BP 2, this basic process is applicable for the criteria of type 1;

$\downarrow$ BP 4 - the pure expert approach. After the conceptual statement, a decision making method is selected and expert estimates are formed. The results of processing the expert estimates are used for ranking the alternatives, then final consideration and decision making are performed. This basic process is applicable for the criteria of types 2 and 3 (theoretically, BP 4 may also be applied for criteria of the type 1 , but this would mean loss of potentially valuable management accounting information, so this variant is not considered).

The estimates used within the basic processes may be either expert-based, or rules-based. The difference is that expert estimates are formed by experts (perhaps, taking into consideration management accounting results), while rules-based estimates are formed directly by transforming management accounting results according to predefined rules, without additional expertise. In fact, the basic processes BP 2 and BP 3 are quite close: both include management accounting calculations and subsequent forming of estimates; the difference is that estimates in BP 2 are rules-based, while BP 3 applies expert estimates.

Ultimately, estimates (expert-based or rules-based) are applied within the basic processes BP 2, BP 3 and BP 4, however expert assessment of alternatives takes place only in BP 3 and BP 4. As to management accounting, it is used in the basic processes BP 1, BP 2 and BP 3 .

In some cases it seems reasonable to use management accounting and the expert approach separately, in their pure forms. Application of pure management accounting (BP 1) is reasonable if there is a single criterion which belongs to type 1 (in this case synthesis of criteria is not required, so additional estimates are excessive). The pure expert approach (BP 4) should be used if all the criteria belong to types 2 and 3 . In the rest of cases, it seems reasonable to combine the management accounting and expert approaches in one or another way.

Working processes, unlike the basic processes, assume the availability of both quantitative and qualitative criteria, as well as processing of information for different criteria in different ways. This means that few basic processes may be combined within the same working process.

Let us consider the most common case, where criteria of all three types are available, and where management accounting results obtained for different criteria of type 1 are used in different ways: for some criteria - in pure form, for others - as a basis for transformation into rules-based estimates, for third cases - as source information for expert estimates. Such a case requires the use of all four basic processes; the appropriate generalized working process is presented in Figure 1.

The working processes relating to particular cases represent different variations of the generalized decision making process. Each of such variations includes a specific set of basic processes (Table 1).

The applicability of the working processes depends on the nature of the criteria involved in decision making tasks:

$\diamond$ working processes WP $1-$ WP 7 are applied if some criteria belong to type 1 , while the rest of the criteria to types 2 and/or 3 (including tasks with criteria of all three types). In this case, at least one of the processes BP 1 - BP 3 (in any combination) and BP 4 are used. If there are criteria of all three types, the working process WP 1 is equal to the generalized process;

$\diamond$ working processes WP 8 - WP 14 are applied if all criteria belong to type 1 . In this case the process WP 4 is not used, only processes BP 1 - BP 3 are applied (separately or in any combination). The working processes WP 8, WP 9 and WP 10 are equal to the basic processes BP 1 (pure management accounting), BP 2 and BP 3 accordingly;

$\diamond$ working process WP 15 is applied if all criteria belong to types 2 and/or 3 . This working process is equal to the basic process BP 4 (the pure expert approach).

It should be noticed that if BP 1 is not used then estimates (either rules-based or expert- based) are formed for all the criteria, with their subsequent processing. If BP 1 is applied, then the task is split into two parts: for some criteria no estimates are applied (management accounting results are used directly in the stage of final consideration and decision making), while with respect to other criteria estimates are formed, with their further processing. 


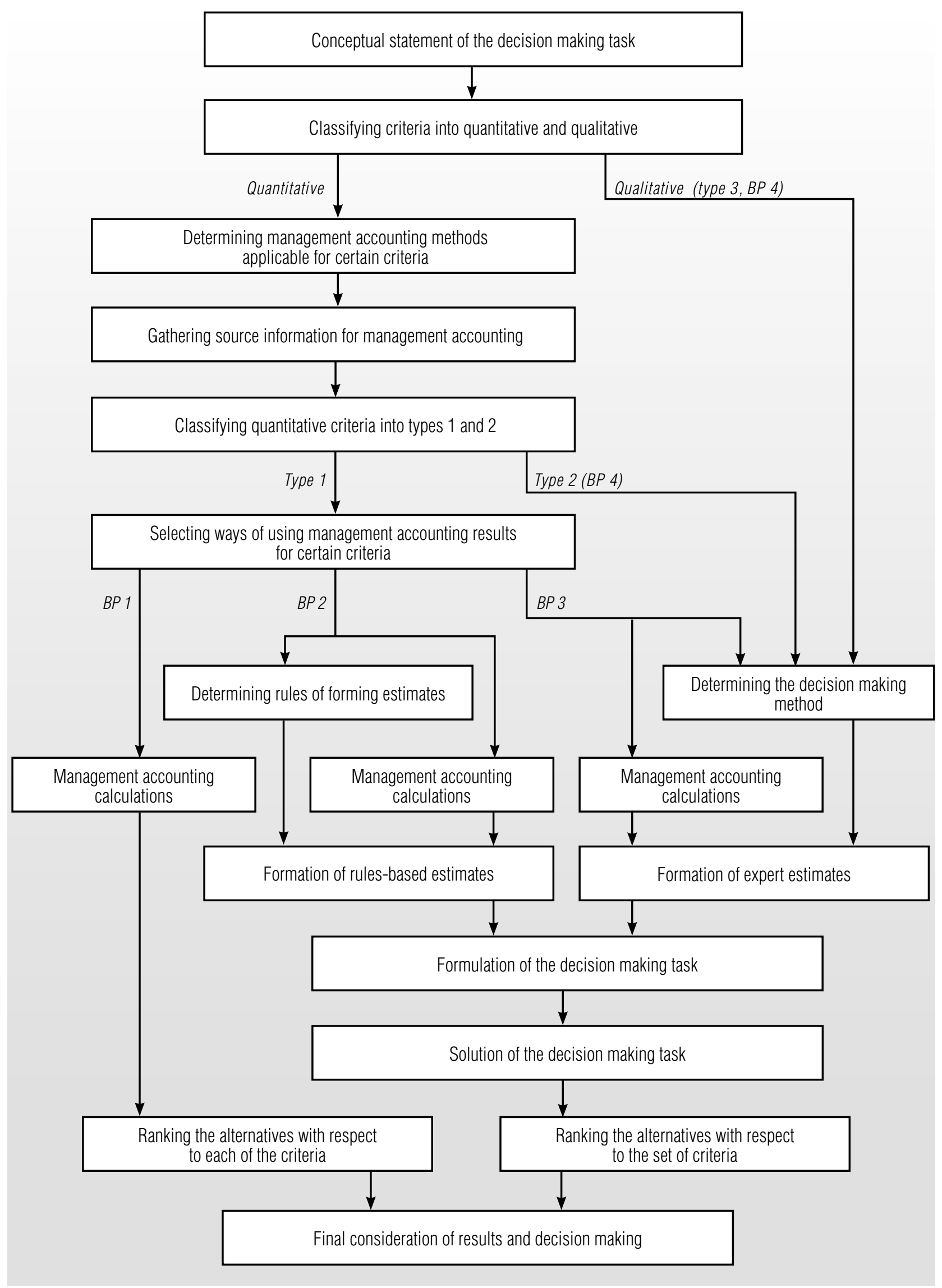

Fig. 1. Generalized working decision making process 
Table 1. $-C_{4}-$ impact of the new product on the enterprise's

Working decision making processes

\begin{tabular}{|c|c|c|c|c|}
\hline \multirow{2}{*}{$\begin{array}{l}\text { Working } \\
\text { processes }\end{array}$} & \multicolumn{4}{|c|}{ Basic processes } \\
\hline & BP 1 & BP 2 & BP 3 & BP 4 \\
\hline WP 1 & + & + & + & + \\
\hline WP 2 & + & - & - & + \\
\hline WP 3 & - & + & - & + \\
\hline WP 4 & - & - & + & + \\
\hline WP 5 & + & + & - & + \\
\hline WP 6 & + & - & + & + \\
\hline WP 7 & - & + & + & + \\
\hline WP 8 & + & - & - & - \\
\hline WP 9 & - & + & - & - \\
\hline WP 10 & - & - & + & - \\
\hline WP 11 & + & + & - & - \\
\hline WP 12 & + & - & + & - \\
\hline WP 13 & - & + & + & - \\
\hline WP 14 & + & + & + & - \\
\hline WP 15 & - & - & - & + \\
\hline
\end{tabular}

\section{Example: Investment appraisal}

As an example, let us consider one of the classical management accounting tasks - investment appraisal.

A manufacturing company examines a few variants of its business development through construction of a new plant and introduction of a new product. This project has an investment nature: it implies initial capital expenditures and subsequent long-term economic benefits. There are three alternatives (variants of development) $X_{1}, X_{2}$ and $X_{3}$. Each of the alternatives are evaluated with respect to six criteria:

- $C_{1}$ - payback period;

- $C_{2}$ - net present value (NPV);

- $C_{3}$ - internal rate of return (IRR); reputation (qualitative, technological, ecological and social matters);

- $C_{5}$ - reliability of operations (risks related to the new product manufacturing and sales, including potential lack of quality and dependence on key suppliers and customers);

- $C_{6}$ - prospects of the new product (possibility of long-term business development).

The criteria $C_{1}, C_{2}$ and $C_{3}$ are quantitative, and the company has all the information required for management accounting. So, these three criteria belong to type 1 and for them management accounting calculations are to be performed. Meanwhile, the decision maker assumes that payback period figures are sufficient for final consideration, while interpreting net present value and internal rate of return requires additional expert assessment - to justify the significance of differences between the figures obtained for different alternatives. This means that with respect to criterion $C_{1}$ the basic process $\mathrm{BP} 1$, and for criteria $C_{2}$ and $C_{3}$ - the basic process BP 3 are used.

As to criteria $C_{4}, C_{5}$ and $C_{6}$, they all are qualitative and belong to type 3 , so for them only the basic process BP 4 is applicable.

Thus, for comparison of the variants of the company's development and final decision making the working process WP 6 involving the basic processes BP 1, BP 3 and BP 4 is to be applied.

As a decision making method for generalizing estimates with respect to criteria $C_{2}-C_{6}$, an analytic hierarchy process (AHP) [4-6] is used. Eventually, the information presented for final consideration consists of payback period figures for the different alternatives (criterion $C_{1}$ ) and the alternatives' priorities determined with respect to criteria $C_{2}-C_{6}$ using the AHP method.

The results of management accounting for the different alternatives with respect to criteria $C_{1}-C_{3}$ are presented in Table 2. As we see in the table, the best value of payback period is related with the alternative $X_{3}$, the best value of net present value - with the alternative $X_{1}$, and the best value of internal rate of return - with the alternative $X_{2}$. The payback period figures are to be presented for final consideration "as is", without any additional assessment. As to the remaining two criteria, their figures are to be used as additional information for forming expert estimates. 
Table 2. ing the analytic hierarchy process method, taking into

Results of management accounting calculations for criteria $C_{1}-C_{3}$

\begin{tabular}{c|c|c|c}
\hline $\begin{array}{c}\text { Alterna- } \\
\text { tives }\end{array}$ & $\begin{array}{c}\text { Payback } \\
\text { period } \\
\left(C_{\mathbf{1}}, \text { years }\right)\end{array}$ & $\begin{array}{c}\text { Net present } \\
\text { value } \\
\left(C_{2}, \text { mln. rubles }\right)\end{array}$ & $\begin{array}{c}\text { Internal rate } \\
\text { of return } \\
\left(C_{3}, \%\right)\end{array}$ \\
\hline $\boldsymbol{X}_{\mathbf{1}}$ & 5.5 & 250.2 & 16.6 \\
\hline $\boldsymbol{X}_{\mathbf{2}}$ & 4.5 & 230.4 & 17.2 \\
\hline $\boldsymbol{X}_{\mathbf{3}}$ & 4.0 & 196.1 & 13.7 \\
\hline
\end{tabular}

The analytic hierarchy process method as a tool for generalizing of expert estimates implies constructing a hierarchical structure "goal-criteria-alternatives" and subsequent pairwise comparison of the elements in each level with respect to the upper level elements. In our case, there are six pairwise comparison sessions: one for comparing criteria with respect to the goal, and five for comparing the alternatives with respect to each of the decision making criteria $\left(C_{2}-C_{6}\right)$.

The results of each session are entered into a pairwise comparison matrix. In any of such matrices, rows and columns represent the compared elements, while the intersections contain their comparative estimates expressed in terms of the verbal-numerical fundamental scale (Saaty's scale). Relying on the estimates, priorities of elements in the lowest hierarchical level (alternatives) with respect to the highest level element(the goal) are calculated ${ }^{1}$.

The pairwise comparison matrix of the criteria and their priorities with respect to the goal are shown in the Table 3, and the pairwise comparison matrix of the alternatives with respect to criteria $C_{2}$ - in the Table 4 (the alternatives' comparison with respect to other criteria is performed similarly). Based on priorities of the criteria with respect to the goal and priorities of the alternatives with respect to each of the criteria, synthesizing overall priorities is executed (Table 5). By applying the working process WP 6 , the following results are subject to final consideration and decision making (Table 6):

$\checkmark$ the values of payback period (criterion $C_{1}$ ) for each of the alternatives determined using management accounting;

$\downarrow$ overall priorities of the alternatives with respect to the remaining five criteria $\left(C_{2}-C_{6}\right)$, determined us- consideration the management accounting results for criteria $C_{2}$ and $C_{3}$.

Table 3.

Pairwise comparison matrix and priorities of the criteria $C_{2}-C_{6}$ with respect to the goal

\begin{tabular}{|c|c|c|c|c|c|c}
\hline \multirow{2}{*}{ Griteria } & \multicolumn{5}{|c|}{ Griteria } & \multirow{2}{*}{ Priorities } \\
\cline { 2 - 6 } & $C_{2}$ & $C_{3}$ & $C_{4}$ & $C_{5}$ & $C_{6}$ & \\
\hline$C_{2}$ & 1 & 2 & 3 & 4 & 4 & $\mathbf{0 . 4 1 4}$ \\
\hline $\boldsymbol{C}_{\mathbf{3}}$ & $1 / 2$ & 1 & 2 & 3 & 3 & $\mathbf{0 . 2 5 7}$ \\
\hline $\boldsymbol{C}_{\mathbf{4}}$ & $1 / 3$ & $1 / 2$ & 1 & 2 & 2 & $\mathbf{0 . 1 5 3}$ \\
\hline $\boldsymbol{C}_{\mathbf{5}}$ & $1 / 4$ & $1 / 3$ & $1 / 2$ & 1 & 1 & $\mathbf{0 . 0 8 8}$ \\
\hline $\boldsymbol{C}_{\mathbf{6}}$ & $1 / 4$ & $1 / 3$ & $1 / 2$ & 1 & 1 & $\mathbf{0 . 0 8 8}$ \\
\hline
\end{tabular}

Table 4.

Pairwise comparison matrix and priorities of the alternatives with respect to the criterion $C_{2}$ (net present value)

\begin{tabular}{c|c|c|c|c}
\hline \multirow{2}{*}{$\begin{array}{c}\text { Alterna- } \\
\text { tives }\end{array}$} & \multicolumn{3}{|c|}{ Alternatives } & \multirow{2}{*}{ Priorities } \\
\cline { 2 - 5 } & $X_{1}$ & $X_{2}$ & $X_{3}$ & \\
\hline$X_{1}$ & 1 & 2 & 6 & $\mathbf{0 . 6 0 0}$ \\
\hline$X_{2}$ & $1 / 2$ & 1 & 3 & $\mathbf{0 . 3 0 0}$ \\
\hline$X_{3}$ & $1 / 6$ & $1 / 3$ & 1 & $\mathbf{0 . 1 0 0}$ \\
\hline
\end{tabular}

Table 5.

Synthesizing to obtain overall priorities

\begin{tabular}{|c|c|c|c|c|c|c}
\hline \multirow{2}{*}{$\begin{array}{c}\text { Alterna- } \\
\text { tives }\end{array}$} & \multicolumn{5}{|c|}{ Griteria and their weights } & \multirow{2}{*}{$\begin{array}{c}\text { Overall } \\
C_{2} \\
\text { priorities }\end{array}$} \\
\cline { 2 - 6 } & $C_{3}$ & $C_{4}$ & $C_{5}$ & $C_{5}$ \\
$(0.257)$ & $(0.153)$ & $(0.088)$ & $(0.088)$ & \\
\hline$X_{1}$ & 0.600 & 0.300 & 0.090 & 0.455 & 0.143 & 0.392 \\
\hline$X_{\mathbf{2}}$ & 0.300 & 0.600 & 0.455 & 0.090 & 0.143 & 0.369 \\
\hline $\boldsymbol{X}_{\mathbf{3}}$ & 0.100 & 0.100 & 0.455 & 0.455 & 0.714 & 0.239 \\
\hline
\end{tabular}

${ }^{1}$ All the calculations are performed using Super Decisions software (www.superdecisions.com) 
Results presented for final consideration and decision making

\begin{tabular}{c|c|c}
$\begin{array}{c}\text { Alter- } \\
\text { natives }\end{array}$ & $\begin{array}{c}\text { Payback period } \\
\text { (eriterion } C_{1} \text {, years) }\end{array}$ & $\begin{array}{c}\text { Estimate with respect } \\
\text { to eriteria } C_{2}-C_{6} \\
\text { (overall priorities) }\end{array}$ \\
\hline $\boldsymbol{X}_{\mathbf{1}}$ & 5.5 & 0.392 \\
\hline $\boldsymbol{X}_{\mathbf{2}}$ & 4.5 & 0.369 \\
\hline $\boldsymbol{X}_{\mathbf{3}}$ & 4.0 & 0.239 \\
\hline
\end{tabular}

As can be seen from the table, when interpreting the results, the decision maker has to make an informal choice, because none of the alternatives has the advantage over the others. Such a situation is typical for all the working processes in which the basic process BP 1 is combined with at least one of the remaining basic processes. In such cases, justification may rely on some additional information about possible variants, as well as on the decision maker's opinion regarding the significance of differences in results obtained for different alternatives.

\section{Conclusion}

Management accounting and expert assessment are two approaches which may be combined for decision making in the field of economics and management.
There are three ways to use the results of management accounting calculations.

First, management accounting results may be considered directly, at the final stage of the decision making process, in parallel with the results of processing of rules-based and expert estimates. In this case, the results of financial and economic calculations (using one or another management accounting method) and the results of estimates processing (using one or another decision making method) are presented for final consideration independently from each other.

Secondly, management accounting results may be used as a background for forming estimates relying on predefined rules (rules-based estimates), without any additional expert assessment. Such estimates are subsequently processed using one of the decision making methods.

Thirdly, management accounting results may be delivered to experts as source information which may be taken into consideration during the formation of expert estimates. Such estimates are also processed using one of the decision making methods.

Different ways of combining the management accounting and expert approaches may be used within the same task but with respect to different criteria. It is also possible to arrange multivariate calculations, where management accounting results for the same criteria are used in different ways depending on the situations under consideration. All this expands the analytical capability and creates a background for more justifiable decision making.

\section{References}

1. Drury C. (2015) Management and cost accounting. London: Cengage Learning EMEA.

2. Atrill P., McLaney E. (2015) Management accounting for decision makers. Harlow, UK: Pearson.

3. Kovalev V.V. (2015) Finansovyy menedzhment: teoriya i praktika [Financial management: theory and practice]. Moscow: Prospect (in Russian).

4. Saaty T.L. (2008) Decision making with the analytic hierarchy process. International Journal of Services Sciences, vol. 1, no. 1, pp. 8398.

5. Saaty T.L., Peniwati K. (2008) Group decision making: Drawing out and reconciling differences. Pittsburgh: RWS Publications.

6. Saaty T.L. (2015) Prinyatie resheniy pri zavisimostyakh i obratnykh svyazyakh: Analiticheskie seti [Decision making with dependence and feedback: The analytic network process]. Moscow: LENAND (in Russian).

7. Roy B. (1991) The outranking approach and the foundation of ELECTRE methods. Theory and Decision, no. 31, pp. 49-73.

8. Brans J.P., Vincke Ph. (1985) A preference ranking organization method. Management Science, no. 31, pp. 647-656.

9. Brans J.P., Vincke Ph., Marechal B. (1986) How to select and how to rank projects: The PROMETHEE method. European Journal of Operational Research, no. 24, pp. 228-238.

10. Brans J.P., Marechal B. (1994) The PROMCALC \& GAIA decision support system for multicriteria decision aid. Decision Support Systems, no. 12, pp. 297-310.

11. Kravchenko T.K. (2010) Ekspertnaya sistema podderzhki prinyatiya resheniy [Expert decision support system]. Open Education, no. 6, pp. 147-156 (in Russian).

12. Figueira J., Greco S., Ehrgott M., eds. (2005) Multiple criteria decision analysis: State of the art surveys. Boston, MA: Springer. 


\title{
Принятие решений на основе сочетания управленческого учета и экспертного подхода
}

\author{
Д.В. Исаев \\ кандидат экономических наук, доцент кафедры бизнес-аналитики \\ Национальный исследовательский университет «Высшая школа экономики» \\ Адрес: 101000, г. Москва, ул. Мясницкая, д. 20 \\ E-mail:disaev@hse.ru
}

\begin{abstract}
Аннотация
В статье рассматриваются вопросы сочетания управленческого учета и экспертного подхода при принятии решений в сфере экономики и менеджмента. Предпосылками такого сочетания является то, что оба подхода предполагают наличие некоторого множества альтернатив и критериев их оценки, вытекающих из цели принятия решения, а также возможность многовариантной оценки альтернатив, в зависимости от рассматриваемых ситуаций.

Базовые процессы принятия решений, предусматривающие однотипную обработку информации, основаны на классификации критериев принятия решений на три типа: количественные критерии, для которых имеется исходная информация для применения управленческого учета, количественные критерии, для которых такая информация отсутствует, и качественные критерии, для которых методы управленческого учета неприменимы. На основе классификации критериев выделены четыре базовых процесса: применение управленческого учета в чистом виде, применение управленческого учета с последующим оцениванием альтернатив по предопределенным правилам, применение управленческого учета с последующей экспертизой и формированием экспертных оценок, применение экспертного подхода в чистом виде.

На основе различных сочетаний базовых процессов выделены пятнадцать рабочих процессов принятия решений, включая обобщенный рабочий процесс, предусматривающий применение всех четырех базовых процессов. Сделаны выводы о практической применимости отдельных рабочих процессов, в зависимости от состава критериев, имеющих место в задачах принятия решений.

Апробация предложенного подхода выполнена на примере задачи обоснования инвестиций в развитие производственной компании, с применением трех классических критериев инвестиционного анализа (период окупаемости, чистая приведенная стоимость, внутренняя норма рентабельности) и трех критериев качественного характера.
\end{abstract}

Ключевые слова: принятие решений, управленческий учет, экспертный подход, оценка альтернатив, инвестиционный анализ, метод анализа иерархий.

Цитирование: Isaev D.V. Decision making using a combination of management accounting and an expert approach // Business Informatics. 2016. No. 4 (38). P. 70-78. DOI: 10.17323/1998-0663.2016.4.70.78.

\section{Литература}

1. Drury C. Management and cost accounting. London: Cengage Learning EMEA, 2015.

2. Atrill P., McLaney E. Management accounting for decision makers. Harlow, UK: Pearson, 2015.

3. Ковалев В.В. Финансовый менеджмент: теория и практика. М.: Проспект, 2015.

4. Saaty T.L. Decision making with the analytic hierarchy process // International Journal of Services Sciences. 2008. Vol. 1. No. 1. P. 83-98.

5. Saaty T.L., Peniwati K. Group decision making: Drawing out and reconciling differences. Pittsburgh: RWS Publications, 2008.

6. Саати Т.Л. Принятие решений при зависимостях и обратных связях: Аналитические сети. М.: ЛЕНАНД, 2015.

7. Roy B. The outranking approach and the foundation of ELECTRE methods // Theory and Decision. 1991. No. 31. P. 49-73.

8. Brans J.P., Vincke Ph. A preference ranking organization method // Management Science. 1985. No. 31. P. 647-656.

9. Brans J.P., Vincke Ph., Marechal B. How to select and how to rank projects: The PROMETHEE method // European Journal of Operational Research. 1986. No. 24. P. 228-238.

10. Brans J.P., Marechal B. The PROMCALC \& GAIA decision support system for multicriteria decision aid // Decision Support Systems. 1994. No. 12. P. 297-310.

11. Кравченко Т.К. Экспертная система поддержки принятия решений // Открытое образование. 2010. № 6. - С. 147-156.

12. Multiple criteria decision analysis: State of the art surveys / Edited by J. Figueira, S. Greco, M. Ehrgott. Boston, MA: Springer, 2005. 
Articles should be topical and original, should outline tasks (issues), describe key results of the author's research and appropriate conclusions.

Manuscripts are submitted via e-mail: bijournal@hse.ru.

\section{MANUSCRIPT REQUIREMENTS}

TEXT FILES should be submitted in electronic form, as a MS Word document (version 2003 or higher).

LENGTH. Articles should be between 20 and 25 thousand characters (incl. spaces).

FONT, SPACING, MARGINS. The text should be in Times New Roman 12 pt, 1.5 spaced, fit to the width, margins: left -25 $\mathrm{mm}$, all other $-15 \mathrm{~mm}$.

TITLE of the article should be submitted in native language and English.

AUTHORS' DETAILS are presented in native language and English. The details include:

$\downarrow$ Full name of each author

$\downarrow$ Position, rank, academic degree of each author

- Affiliation of each author, at the time the research was completed

$\downarrow$ Full postal address of each affiliation (incl. postcode / ZIP)

$\downarrow$ E-mail address of each author.

\section{ABSTRACT are presented in native language and English.}

- The abstract should be between 200 and 300 words.

$\downarrow$ The abstract should be informative (no general words), original, relevant (reflects your paper's key content and research findings); structured (follows the logics of results' presentation in the paper)

- The recommended structure: purpose (mandatory), design / methodology / approach (mandatory), findings (mandatory), research limitations / implications (if applicable), practical implications (if applicable), originality / value (mandatory).

$\uparrow$ It is appropriate to describe the research methods/methodology if they are original or of interest for this particular research. For papers concerned with experimental work the data sources and data procession technique should be described.

- The results should be described as precisely and informatively as possible. Include your key theoretical and experimental results, factual information, revealed interconnections and patterns. Give special priority in the abstract to new results and long-term impact data, important discoveries and verified findings that contradict previous theories as well as data that you think have practical value.

- Conclusions may be associated with recommendations, estimates, suggestions, hypotheses described in the paper.

$\downarrow$ Information contained in the title should not be duplicated in the abstract. Authors should try to avoid unnecessary introductory phrases (e.g. "the author of the paper considers...»).

- Authors should use the language typical of research and technical documents to compile your abstract and avoid complex grammatical constructions.

$\downarrow$ The text of the abstract should include key words of the paper.

KEYWORDS are presented in native language and English. The number of key words / words combinations are from 6 to 10 (separated by semicolons).

FORMULAE should be prepared using Math Type or MS Equation tool.

FIGURES should be of high quality, black and white, legible and numbered consecutively with Arabic numerals. All figures (charts, diagrams, etc.) should be submitted in electronic form (photo images - in TIF, PSD or JPEG formats, minimum resolution $300 \mathrm{dpi}$ ). Appropriate references in the text are required.

REFERENCES should be presented in Harvard style and carefully checked for completeness, accuracy and consistency.

The publication is free of charge. 
Представляемая для публикации статья должна быть актуальной, обладать новизной, отражать постановку задачи (проблемы), описание основных результатов исследования, выводы, а также соответствовать указанным ниже правилам оформления.

Текст должен быть тщательно вычитан автором, который несет ответственность за научно-теоретический уровень публикуемого материала.

Материалы представляется в электронном виде по адресу:

bijournal@hse.ru.

\section{ТРЕБОВАНИЯ К ОФОРМЛЕНИЮ СТАТЕЙ}

ТЕКСТ СТАТЬИ представляется в редакцию в электронном виде (в формате MS Word, версия 2003 или выше).

ОБЪЕМ. Ориентировочный объем статьи составляет 20-25 тысяч знаков (с пробелами).

\section{ШРИФТ, ФОРМАТИРОВАНИЕ, НУМЕРАЦИЯ СТРАНИЦ}

ШРИФТ - Times New Roman, кегль набора - 12 пунктов, полуторный интервал, форматирование по ширине. Нумерация страниц вверху по центру, поля: левое - 2,5 см, верхнее, нижнее и правое по $1,5 \mathrm{~cm}$.

НАЗВАНИЕ СТАТЬИ ПрИводится на рУсСКом и английском язЫках. Название статьи должно быть информативным и раскрывать содержание статьи.

СВЕДЕНИЯ ОБ АВТОРАХ прИВОДятСя На русСКом И англиЙСКОМ языках и включают следующие элементы:

$\downarrow$ фамилия, имя, отчество всех авторов полностью

$\downarrow$ должность, звание, ученая степень каждого автора

$\checkmark$ полное название организации - места работы каждого автора в именительном падеже, полный почтовый адрес каждой организации (включая почтовый индекс)

\ адрес электронной почты каждого автора.

АННОТАЦИЯ К СТАТЬЕ представляется на русском и английском языках.

$\uparrow$ Объем - 200-300 слов.

^ Аннотация должна быть информативной (не содержать общих слов).

$\downarrow$ Аннотация должна отражать основное содержание статьи и быть структурированной (следовать логике описания результатов в статье).

$\downarrow$ Структура аннотации: предмет, цель, метод или методологию проведения исследования, результаты исследований, область их применения, выводы.

\ Метод или методологию проведения исследований целесообразно описывать в том случае, если они отличаются новизной или представляют интерес с точки зрения данной работы. В аннотациях статей, описывающих экспериментальные работы, указывают источники данных и характер их обработки.

$\downarrow$ Результаты работы описывают предельно точно и информативно. Приводятся основные теоретические и экспериментальные результаты, фактические данные, обнаруженные взаимосвязи и закономерности. При этом отдается предпочтение новым результатам и дан- ным долгосрочного значения, важным открытиям, выводам, которые опровергают существующие теории, а также информации, которая, по мнению автора, имеет практическое значение.

- Выводы могут сопровождаться рекомендациями, оценками, предложениями, гипотезами, описанными в статье.

$\checkmark$ Сведения, содержащиеся в названии статьи, не должны повторяться в тексте аннотации. Следует избегать лишних вводных фраз (например, «автор статьи рассматривает...»).

\ Исторические справки, если они не составляют основное содержание документа, описание ранее опубликованных работ и общеизвестные положения, в аннотации не приводятся.

$\downarrow$ В тексте аннотации следует употреблять синтаксические конструкции, свойственные языку научных и технических документов, избегать сложных грамматических конструкций.

$\downarrow$ В тексте аннотации следует применять значимые слова из текста статьи

КЛЮЧЕВЫЕ СЛОВА привОДяТся на рУсском И ангЛийском яЗЫкаХ. Количество ключевых слов (словосочетаний) - 6-10. Ключевые слова или словосочетания отделяются друг от друга точкой с запятой.

ФОРМУЛЫ. При наборе формул, как выключных, так и строчных, должен быть использован редактор формул MS Equation. B формульных и символических записях греческие (русские) символы, а также математические функции записываются прямыми шрифтами, а переменные аргументы функций в виде английских (латинских) букв наклонным курсивом (пример «cos a», «sin b», «min», «max»). Нумерация формул - сквозная (по желанию авторов допускается двойная нумерация формул с указанием структурного номера раздела статьи и, через точку, номера формулы в разделе).

РИсунки (графики, диаграммы и т.п.) могут быть оформлены средствами MS Word или MS Excel. Ссылки на рисунки в тексте обязательны и должны предшествовать позиции размещения рисунка. Допускается использование графического векторного файла в формате wmf/emf или cdr v.10. Фотографические материалы предоставляются в формате TIF или JPEG, с разрешением изображения не менее 300 точек на дюйм. Нумерация рисунков - сквозная.

ТАБЛИЦЫ оформляются средствами MS Word или MS Excel. Нумерация таблиц - сквозная.

СПИСОК ЛИТЕРАТУРЫ Составляется В СоОтветствиИ С требованиями ГОСТ 7.0.5-2008. Библиографическая ссылка (примеры оформления размещены на сайте журнала http://bi.hse.ru/). Нумерация библиографических источников - в порядке цитирования. Ссылки на иностранную литературу - на языке оригинала без сокращений.

СПИСОК ЛИТЕРАТУРЫ ДЛЯ АНГЛОЯЗЫЧНОГО БЛОКА оформляется в соответствии с требованиями SCOPUS (примеры оформления размещены на сайте журнала http://bi.hse.ru/). Для транслитерации русскоязычных наименований можно воспользоваться сервисом http://translit.ru/.

\section{ЛИЦЕНЗИОННЫЙ ДОГОВОР}

Для размещения полнотекстовых версий статей на сайте журнала с авторами заключается лицензионный договор о передаче авторских прав.

Плата с авторов за публикацию рукописей не взимается. 